\title{
Investigations of plant subfossil \\ cuticles at a Holocene raised bog complex, northern New Zealand
}

\author{
Carolin Jacqueline Haenfling
}

A thesis submitted to Victoria University of Wellington in partial fulfilment of requirements for the degree of Master of Science in Physical Geography

School of Geography, Environment and Earth Sciences

Victoria University of Wellington

March 2015 


\section{Abstract}

Subfossil plant cuticles, the very resistant waxy layer covering vascular land plants, are a neglected source of information in peat studies, despite their high preservation and identification potential. A lack of standardised methods and reference material are major contributing factors. In this thesis, a new method is introduced to test if subfossil plant cuticles from Moanatuatua Bog in the northern North Island of New Zealand can give a robust reconstruction of local bog surface vegetation changes during the Holocene. The method was successfully established and applied at coarse sampling resolution to show vegetation changes across the full length of the core and at fine sampling resolution around charcoal layers to reconstruct the post-fire response pattern of the main plant species on the bog. Additionally, bulk density and organic matter analyses were carried out to provide further insight into these changes. At the core site, towards the southern margins of Moanatuatua Bog, swamp forest had developed by $15000 \mathrm{cal}$ yr BP. Until ca. $10500 \mathrm{cal} \mathrm{yr} \mathrm{BP,} \mathrm{the} \mathrm{vegetation}$ assemblage was sedge-dominated, indicating swamp and/or fen conditions. A significant increase in macroscopic charcoal particles coincided with the transition to a more diversified vegetation composition. At around $4500 \mathrm{cal} \mathrm{yr} \mathrm{BP}$, the vegetation became restiad-dominated, indicating full raised bog conditions. The coarse resolution cuticle results were further compared to a pollen record from the same sequence, which was established independently. This comparison showed that plant subfossil cuticles can provide additional information to pollen analysis in cases where pollen is hard to identify or poorly preserved. Specifically, restiad pollen is hard to differentiate, yet cuticles of Empodisma and Sporadanthus have very distinct features. Also, Cyperaceae pollen is very poorly preserved at Moanatuatua Bog and the Cyperaceae pollen curve shows a poor match with the Cyperaceae cuticle record. It is suggested therefore that Cyperaceae pollen at this site - and potentially other peat sites - is a less reliable indicator of local sedge communities than a Cyperaceae cuticle record. At fine resolution, results were blurred across a time interval that was marginal for reconstructing response patterns due to the constraints imposed by sampling resolution and peat accumulation rate of Moanatuatua Bog. Nevertheless, two out of three charcoal layers recorded a local fire on the bog surface, with one 
layer displaying the expected vegetation response. After the fire, Empodisma, as a mid-successional species, re-established on the bog surface before Sporadanthus, a late-successional species. The other layer was dominated by sedges and showed no response pattern, as is to be expected due to the very fast recovery of sedges. In general, sample preparation for cuticle analysis proved to be fast with relatively little equipment or chemicals needed. With detailed reference material, identification to species level is possible due to distinctive and pronounced cuticle features. Plant cuticle analysis is therefore proposed to be a reliable tool to reconstruct long-term and short-term vegetation changes from peat sequences. 


\section{Acknowledgements}

I would like to thank my supervisor Dr. Rewi Newnham (Victoria University of Wellington) and my honorary supervisor Andrew Rees (Victoria University of Wellington). I greatly appreciated your help, support, constructive feedback and your patient and thoughtful editing of this thesis.

I would also like to thank Ignacio Jara (Victoria University of Wellington) for his help with sub-sampling the core, teaching me how to use Tilia and allowing me access to his pollen and radiocarbon data for Moanatuatua Bog.

Also, thank you to Aline Homes (Victoria University of Wellington) for her help with plant identification, questions about bog development and allowing me access to her plant cuticle reference collection.

On a more personal note, a big thank you to my friends and family for their boundless support despite the $18000 \mathrm{~km}$ between us. Special thanks to Mama, Papa und Ina for their encouragement, for being incredibly understanding with my decision to study and live on the other side of the world and for getting up each Sunday morning for our weekly Skype date.

Finally, I would like to thank my husband Daniel for being at my side, for keep reminding me that there is a world outside Uni and for being incredibly patient. 


\section{Preface}

I, Carolin Jacqueline Haenfling, declare that this thesis and the work presented in it are my own, unless stated otherwise. All references have been quoted and all sources of information and data have been acknowledged. Nevertheless, I would like to clearly point out all contributions to this thesis:

- Raw pollen data and microscopic charcoal record: Ignacio Jara, VUW

- Raw radiocarbon dates: Ignacio Jara, VUW

- Fieldwork (extraction of cores): Ignacio Jara (VUW), Rewi Newnham (VUW), Matt Ryan (VUW), David Lowe (University of Waikato) and Courtney Foster (University of Waikato)

- Plant cuticle reference collection: Aline Homes, VUW 


\section{List of Figures}

Figure 1: Plant cuticle structure 11

Figure 2: Conceptual cross-sectional view of an ombrotrophic peatland ......................14

Figure 3: Location of Moanatuatua Bog in the Waikato Region .................................. 15

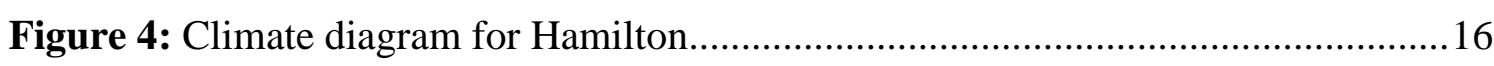

Figure 5 (left): Landscape pattern of the Waikato Region......................................... 17

Figure 6 (right): The most prominent abandoned courses of the Waikato River...........17

Figure 7: Moanatuatua Bog with tall Sporadanthus and smaller Empodisma plants .....19

Figure 8: Stratigraphy of core 1201 and 1202 and resulting composite record ..............29

Figure 9: Summary of plant macrofossil sampling strategy. ....................................... 31

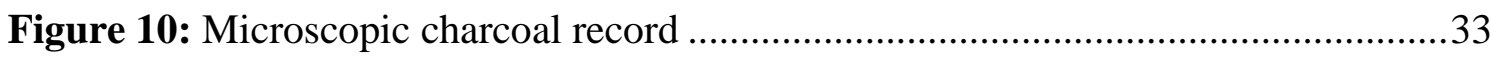

Figure 11: Drive 1202R3B and sampling location for fine-resolution analysis, F3B ....34

Figure 12: Drive 1202R6A and sampling location for fine-resolution analysis, F6A ....35

Figure 13: Drive 1202R2A and sampling location for fine-resolution analysis, F2A ....35

Figure 14: Sample preparation. Disaggregating sample material .................................36

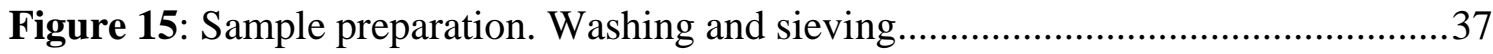

Figure 16: QLC method, modified QLC method, and plant cuticle analysis..................39

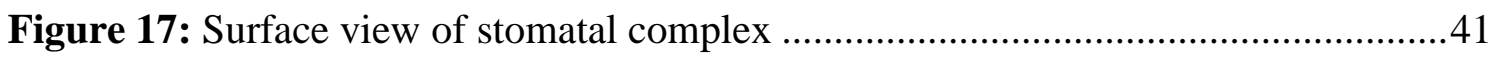

Figure 18: Sampling location for bulk density and loss-on-ignition analysis ...............44

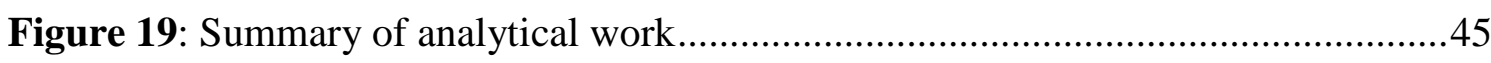

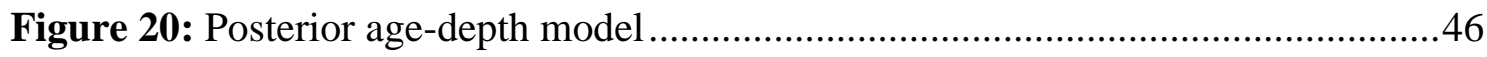

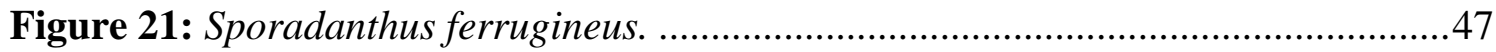

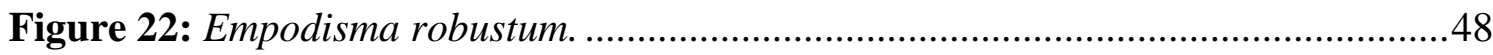

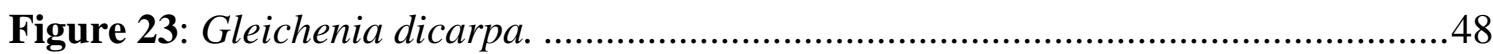

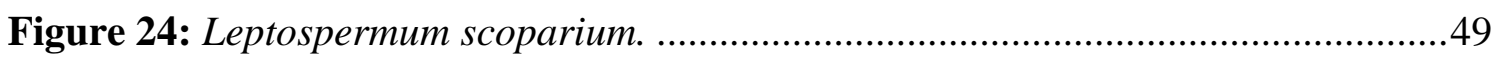

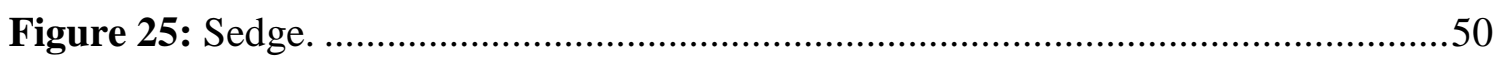

Figure 26: Results of plant cuticle analysis at coarse resolution ..................................52

Figure 27: Bulk density and LOI results for the whole core .......................................54

Figure 28: Results of plant cuticle analysis at fine resolution for layer F6A..................58

Figure 29: Results of plant cuticle analysis at fine resolution for layer F3B.................59

Figure 30: Results of plant cuticle analysis at fine resolution for layer F2A.................60

Figure 31: Bulk density and LOI results for fine resolution analysis ...........................61 
Figure 32: Macroscopic and microscopic charcoal record........................................66

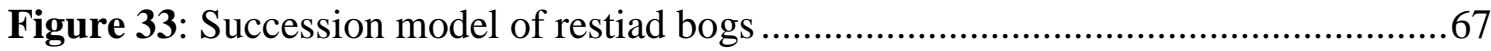

Figure 34: Comparison of main species as recorded by plant cuticles and pollen. ........69

Figure 35: General vegetation cover trends at Moanatuatua Bog since fire event .........73

Figure 36: Summary of response of main plant species based on plant cuticles ............74 


\section{List of Tables}

Table 1: Definition of important terms describing peatlands and their analysis ..............5

Table 2: Main proxies used in peatland studies and their purpose ................................6

Table 3: Summary of advantages, limitations and assumption of plant macrofossil analysis and palynology

Table 4: Bog vegetation succession through time and main moisture indicator plant species at Moanatuatua Bog. .22

Table 5: Major modern plant species of restiad bogs in the Waikato Region................23

Table 6: Summary of fire-adaptations of main bog plant species .................................26

Table 7: Specific and non-specific peat components .....................................................40

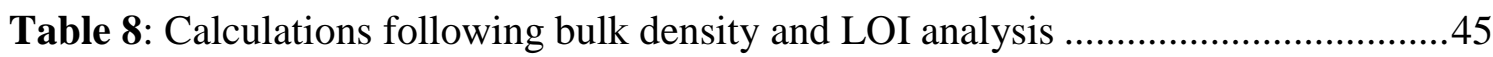

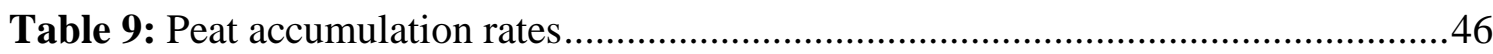

Table 10: Description of sample remains at coarse resolution.....................................50

Table 11: Depth, age and defining characteristics of vegetation zones .........................53

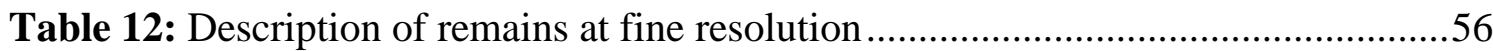

Table 13: Holocene vegetation and bog development of Moanatuatua Bog based on plant macrofossil analysis 


\section{Table of Contents}

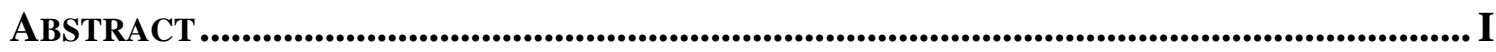

ACKNOWLEDGEMENTS ........................................................................................ III

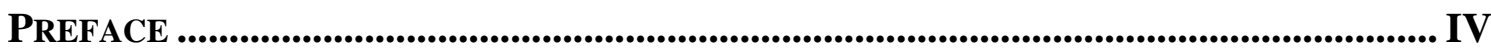

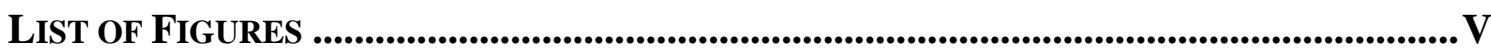

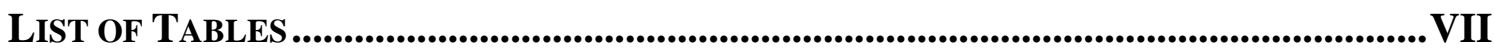

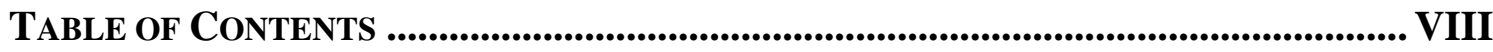

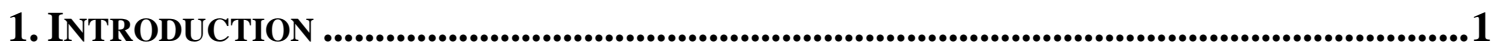

1.1 Motivation: Peatlands as climate archives and their analysis ..............................1

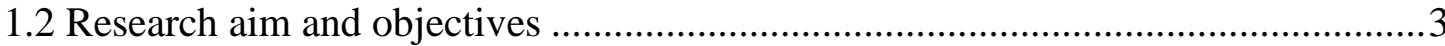

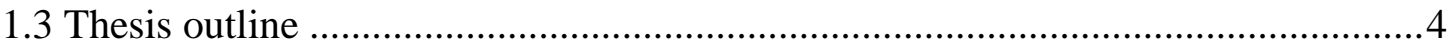

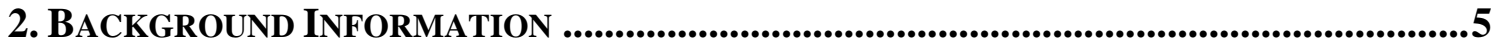

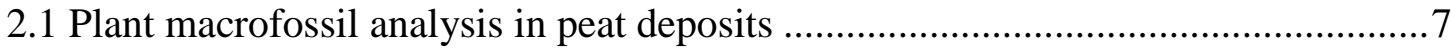

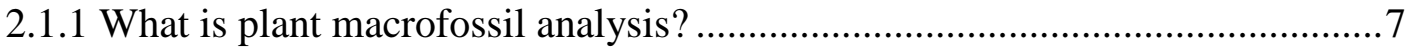

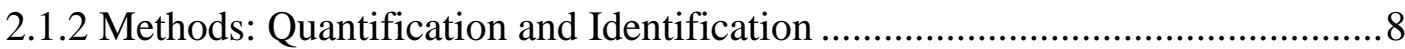

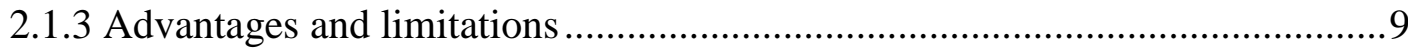

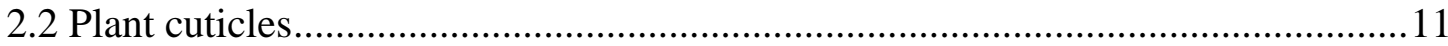

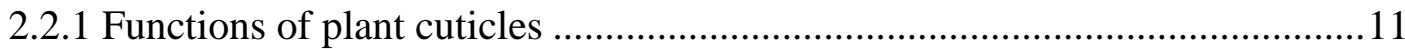

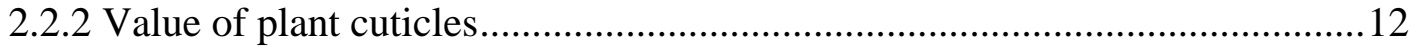

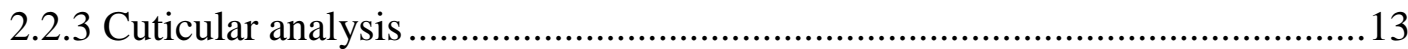

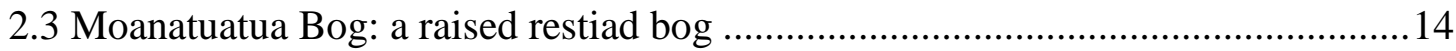

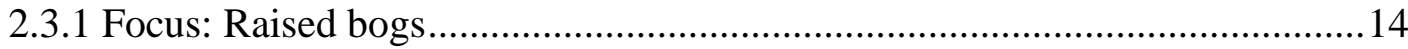

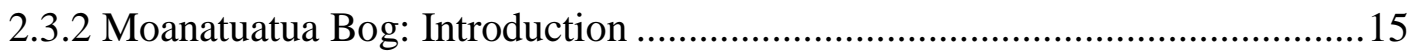

2.3.2 Development of raised bogs in the Waikato Region.....................................17

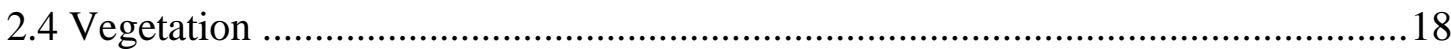

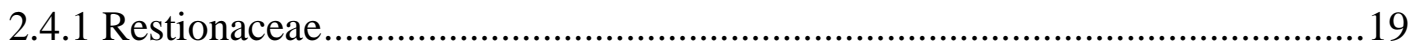

2.4.2 Vegetation succession in a peat bog........................................................21

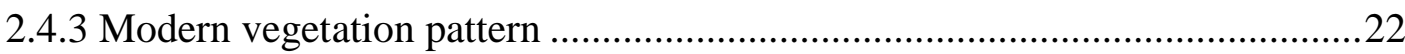

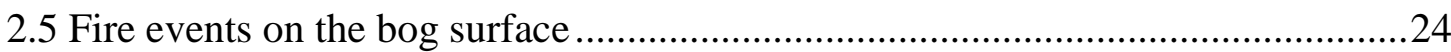


2.5.1 Introduction: Fires on wetlands .24

2.5.2 Vegetation response .25

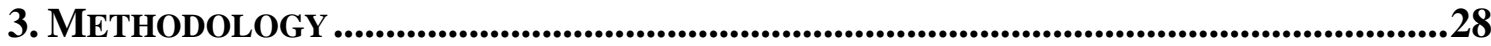

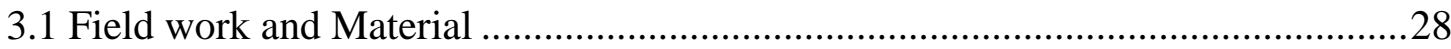

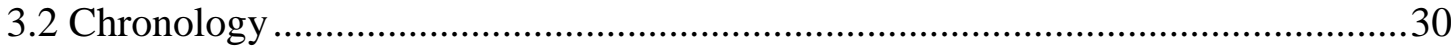

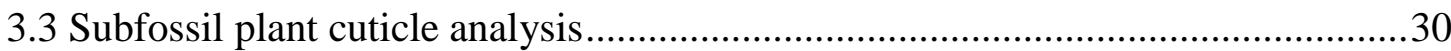

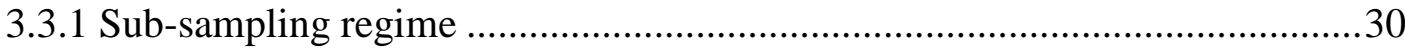

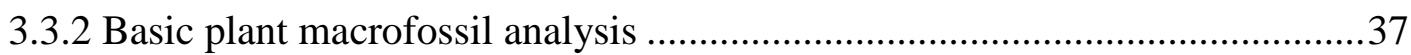

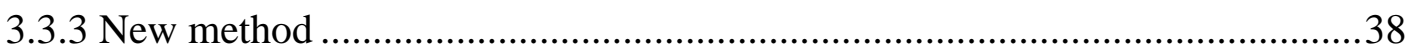

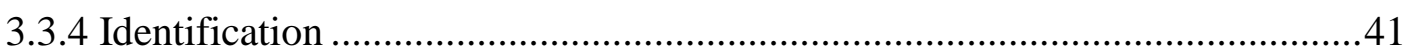

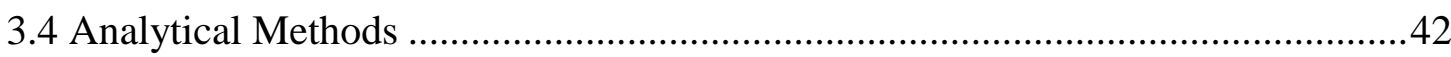

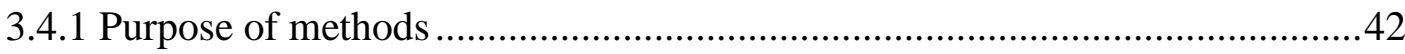

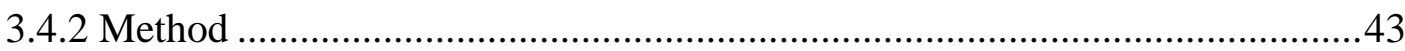

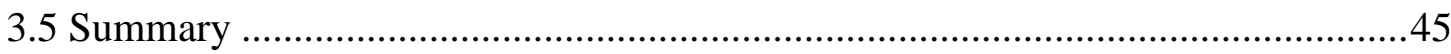

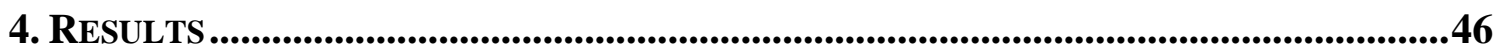

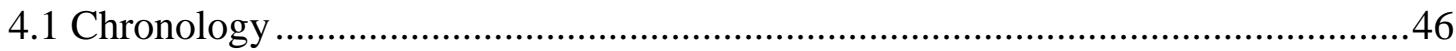

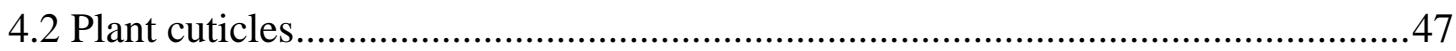

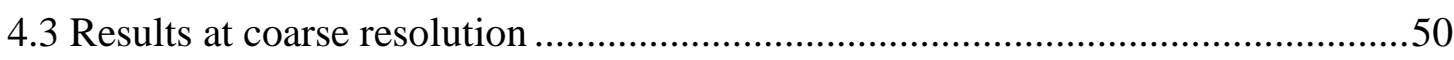

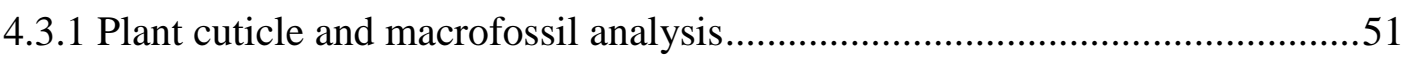

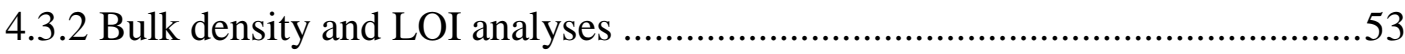

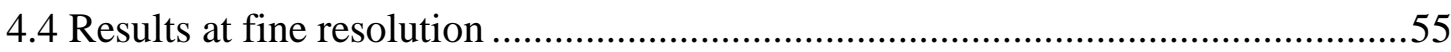

4.4.1 Plant cuticle and plant macrofossil analysis...............................................56

4.4.2 Bulk density and LOI analyses .............................................................61

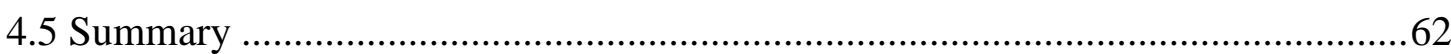

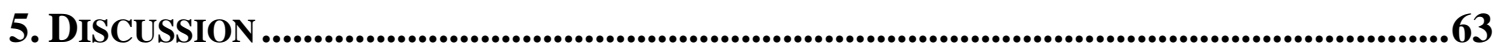

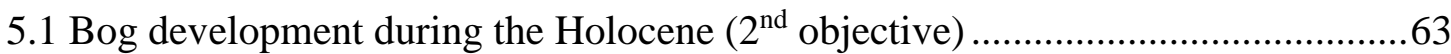

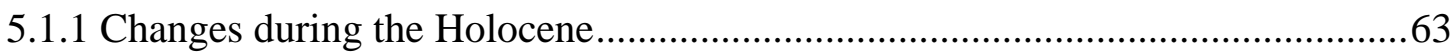

5.1.2 Comparison of plant cuticle record with pollen record................................68

5.1.3 Use of bulk density and organic matter to indicate tephra layers ...................71

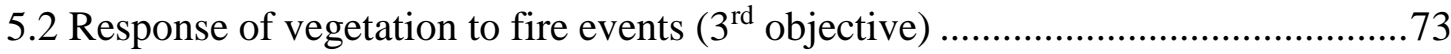




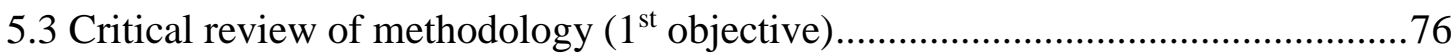

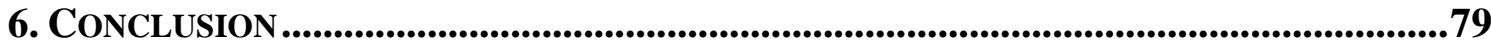

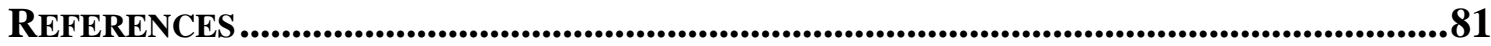

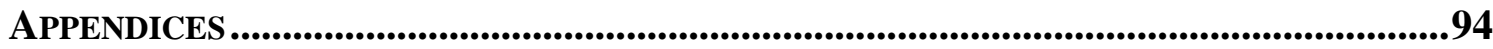

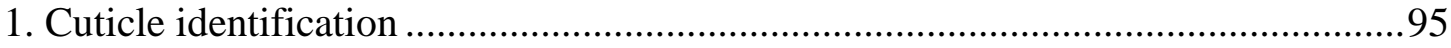

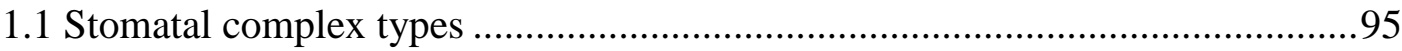

1.2 Terminology for epidermal cell patterns in plant cuticle analysis ....................98

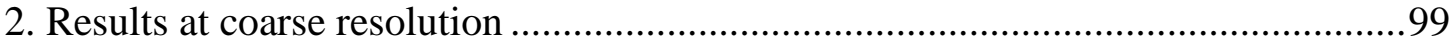

2.1 raw plant cuticle and plant macrofossil data .................................................... 100

2.2 raw bulk density and organic matter data ......................................................101

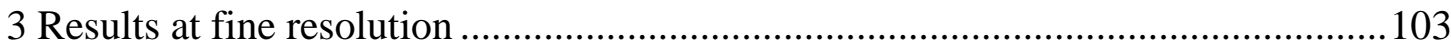

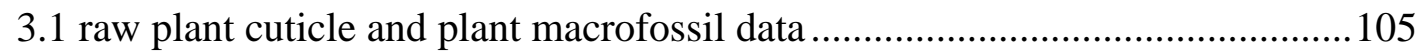

3.2 raw bulk density and organic matter data .................................................... 107

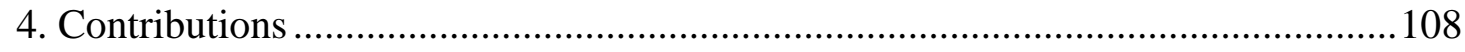

4.1 sample depths of plant macrofossils used for radiocarbon dating and

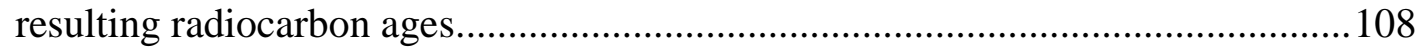

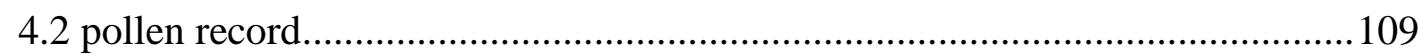




\section{INTRODUCTION}

Peatlands, and in particular raised peat bogs, can provide a local scale record of environmental change over time as they contain an archive of past vegetation communities. Reconstructions are however, only as robust as the proxies upon which they are based. Both palynology and plant macrofossil analysis, as two of the main proxies analysed in peat studies, are associated with advantages, limitations and underlying assumptions. This study intends to apply the method of plant cuticle (waxy layer surrounding vegetative plant parts) analysis at a peat bog, as plant subfossil cuticles are an overlooked tool in peat studies. The following sections will offer a brief introduction to the history of peatlands as climate archives and the use of plant macrofossils. An explanation of the advantages and properties of plant cuticles provides the motivation for the proposed thesis aim and objectives presented towards the end of this chapter. The chapter concludes with a brief outline of the content of each of the following five chapters.

\subsection{Motivation: Peatlands as climate archives and their analysis}

Since the late $19^{\text {th }}$ century, raised (rain-fed) peat bogs in northern Europe have been recognized to be of major value for reconstructions of past climates and environmental histories (e.g. Blytt, 1876; Sernander, 1908), especially with regards to the Holocene epoch (Blackford, 1993; Chambers et al., 2012). Peat bogs were identified as excellent sources of subfossil plant remains due to their sequential deposition and anaerobic and acid nature, which reduces decomposition (Rydin \& Jeglum, 2006; Taylor et al., 2009). Identification of plant remains from different 'layers' of a peat deposit via comparison with modern species enables the reconstruction of former plant assemblages (e.g. Campbell, 1975; Johnson \& Gerbeaux 2004). Furthermore, due to the separation of raised bogs from the influence of groundwater, their only nutrient and moisture input comes from precipitation rather than from groundwater or runoff. Hence, it was proposed that vegetation assemblages on the bog surface must respond to changes in wetness and temperature over time and therefore are expected to display a palaeoclimatic signal (Barber et al., 1994; Mauquoy \& Barber, 1999). In northern Europe this relationship, inferred from plant remains in peat bogs, led to the development of the first 
systematic, postglacial climatostratigraphic scheme, which provided the necessary evidence that significant climatic changes occurred during the Holocene (Blackford, 1993; Rydin \& Jeglum, 2006; Anderson et al., 2013; Clarke, 2013). Subsequently, quantitative plant macrofossil analysis as well as palynology (Chapter 2.1) became standard tools to study raised bogs in the second half of the $20^{\text {th }}$ century (e.g. Barber et al., 1994; Chiverell, 2001; Barber et al., 2003; Booth \& Jackson, 2003; Langdon et al., 2003; Mauquoy \& Yeloff, 2008).

Plant macrofossils are fragmented or entire remains of plants that become incorporated, and subsequently preserved, in sedimentary sequences and deposits. They consist of reproductive (fruits, seeds) and vegetative (wood, leaves, roots) plant parts, which are visible to the naked eye due to their median size of $0.5-2 \mathrm{~mm}$ (e.g. Birks \& Birks, 1980; Warner, 1988; Birks \& Birks, 2005; Mauquoy et al., 2011). These plant remains are all readily analysed in peat studies across the world (e.g. Newnham et al., 1995; Barber et al., 2003; Barber et al., 2004). Plant cuticles, the waxy, resistant layer that covers all vascular land plants, however, are one type of plant macrofossil that are not yet routinely analysed in Holocene peat studies. Importantly, cuticles contain an impression of the epidermal cell morphology and preserve very well in peat deposits (Pole, 2007a; Taylor et al., 2009). It is this impression of the cell structures that potentially makes plant cuticles so valuable. Because distinct features such as stomata and guard cells are unique to each species similar to a human fingerprint, cuticles can be used to accurately identify individual plant species (Chapter 2.2). This is especially important for palaeobotany because with the other widely employed method, pollen analysis, some species can be hard to identify and certain taxa may be under-represented due to low pollen production or poor pollen preservation. Cuticle analysis in peat deposits would therefore enable quicker and more accurate plant identification (Mauquoy et al., 2011). Due to their excellent preservation potential, ease of identification and abundance in Holocene material, subfossil plant cuticles should be a significant tool in peat studies and play a substantial role in plant macrofossil analysis.

Peat deposits also contain an archive of past disturbances on the bog surface, such as fires. They are recognised in the form of charcoal layers, where macroscopic charcoal peaks indicate local fires on the bog surface (Scott \& Jones, 1991; 
McGlone, 2009; Taylor et al., 2009; Mooney \& Tinner, 2011; Mooney et al., 2011). Fires are an interruption to the natural bog development and its plant successional pathway as they remove vegetation and set the bog development back to an earlier stage (Chapter 2.5) (McGlone et al., 1984; Clarkson, 1997; Rydin \& Jeglum, 2006; Sharitz \& Pennings, 2006; McGlone, 2009). This thesis aims to provide information about the response and recovery time of the bog vegetation to fire events on the bog surface.

\subsection{Research aim and objectives}

In this study, I will analyse plant macrofossil remains from two peat cores (together approximately 9-m long) from rain-fed Moanatuatua Bog in the northern North Island of New Zealand. The aim is to test if subfossil plant cuticles can give a robust reconstruction of local bog surface vegetation changes during the Holocene. To achieve this aim, three objectives are addressed:

1st: To develop a new method in order to retrieve, identify and quantify subfossil plant cuticles from Moanatuatua Bog.

$\mathbf{2}^{\text {nd: }} \quad$ To apply this technique at coarse resolution sub-sampling at regular intervals across the whole length of the sequence to reconstruct changes in the local vegetation assemblage during the Holocene.

To compare these results with a pollen record for the same sequence developed independently by Ignacio Jara, Victoria University of Wellington (VUW).

$3^{\text {rd: }} \quad$ To apply the new method at fine resolution sub-sampling shortly before and after three key charcoal layers in the sequence in order to reconstruct changes in the vegetation assemblage in response to fire events on the bog surface. This line of inquiry is intended to provide information about the response and recovery time of bog flora to fire events.

The two principal bog species Empodisma robustum and Sporadanthus ferrugineus will be the focus of the plant cuticle analysis as their cuticles have the advantage of 
being much easier to distinguish from one another than their respective pollen. Furthermore, both species are currently the main peat-forming plants on Moanatuatua Bog and are thought to be key players in the developmental history of the bog. In order to verify the cuticle record, the results from the coarse resolution analysis will be compared with a pollen record (where Empodisma robustum and Sporadanthus ferrugineus are believed to be successfully identified) for the same sedimentary sequence developed independently by Ignacio Jara (VUW). The results of objectives two and three will provide opportunities to test if subfossil plant cuticles can give a robust reconstruction of local bog surface vegetation changes during the Holocene and the response of vegetation assemblages to fire events. Two other analytical techniques will help provide further information about the development of the bog at both scales of resolution. Bulk density will be measured in order to characterize the state of peat decomposition, while the amount of organic matter in the peat will be calculated by loss-on-ignition (LOI). In summary, all results will demonstrate the application of plant cuticle analysis for reconstructing vegetation changes in New Zealand raised bogs during the Holocene at both the long-term geological scale (coarse resolution) and the short-term ecological scale (fine resolution).

\subsection{Thesis outline}

This thesis contains six chapters arranged as follows: The following chapter (Chapter 2) is a literature review and provides background information that is important to this study. It introduces plant macrofossil analysis and highlights the values of plant cuticle analysis. Before describing Moanatuatua Bog as the field location, the particular features of raised bogs, which make them excellent sources for palaeoclimatic and palaeoenvironmental reconstructions, are explained. After providing information about the unique vegetation assemblage, fire events and their impact on the bog surface are discussed. Chapter 3 outlines the methodology and delineates the laboratory techniques and analyses employed in this study. The results at both scales of resolution are presented in Chapter 4 together with the results of the analytical methods used at coarse as well as fine resolution. A discussion of results and a critical review of the newly established cuticle analysis technique can be found in Chapter 5. Conclusions are then drawn in the final chapter, Chapter 6. 


\section{BACKGROUND INFORMATION}

The scope of research into peatlands as climate archives is broad and extends across a wide-range of sub-disciplines (Table 2). This chapter will therefore focus on the topics most relevant to the research undertaken in this thesis (Table 1). For further information concerning the use of peatlands in reconstructing palaeoclimatic conditions, see e.g. Blackford (1993), Johnson \& Gerbeaux (2004), Batzer \& Sharitz (2006), and Rydin \& Jeglum (2006). The following sections will provide information about the use of plant macrofossils (Chapter 2.1), one of the key methods for studying peat deposits. Plant cuticle analysis (Chapter 2.2) as the focus of this work will be introduced before explaining why Moanatuatua Bog (Chapter 2.3) is a good place to test if subfossil plant cuticles can give a robust reconstruction of local bog surface vegetation changes during the Holocene. Also, the effect of fires on the bog surface (Chapter 2.5) and the response of the local vegetation (Chapter 2.4) to fire events is discussed.

Table 1: Definition of important terms describing peatlands and their analysis in this study

\begin{tabular}{|l|l|}
\hline TERM & EXPLANATION \\
\hline Mire & Actively peat-accumulating wetland, 2 types of mire: bog and fen \\
\hline \multicolumn{2}{|l|}{ Bog } \\
\hline Ombrotrophic & Method of nutrient supply: only by rainfall \\
\hline Ombrogenous & Origin of nutrients: only rainwater \\
\hline Oligotrophic & Nutrient status: poor \\
\hline Raised peatland & Peatland that is raised above the surrounding terrain and therefore isolated from groundwater \\
\hline Rain-fed & Peatland with rainwater as single water supply (often raised peatlands or bogs) \\
\hline \multicolumn{2}{|l|}{ Fen } \\
\hline Minerotrophic & Nutrient status: high \\
\hline Minerogenous & Origin of nutrients: groundwater, runoff, rainwater \\
\hline \multicolumn{2}{|l|}{} \\
\hline Angiosperm & Seed-producing flowering plant whose seeds are enclosed within an ovary (e.g. fruit) \\
\hline Gymnosperm & $\begin{array}{l}\text { Seed-producing non-flowering plant whose seeds are unenclosed or "naked" (e.g. on surface } \\
\text { of scales, leaves or cones) }\end{array}$ \\
\hline Epidermis & $\begin{array}{l}\text { Protective outermost cell layer covering all plant organs such as roots, stems and leaves; } \\
\text { wrapped in another protective layer, the cuticle }\end{array}$ \\
\hline Cuticles & $\begin{array}{l}\text { Waxy, very resistant layer covering the aerial parts of land plants such as leaves, non-woody } \\
\text { stems and fruits }\end{array}$ \\
\hline & Pore on epidermis, which allows gas exchange with atmosphere \\
\hline Guarding stomata: control opening and closure of stomata \\
\hline
\end{tabular}


Table 2: Main proxies used in peatland studies and their purpose (after Barber, 1993; Chambers \& Charman, 2004; Chambers et al., 2012)

\begin{tabular}{|c|c|c|}
\hline PEATLAND & PROXIES & PURPOSE \\
\hline \multirow{8}{*}{$\begin{array}{c}\text { Physical and } \\
\text { Chemical } \\
\text { Properties }\end{array}$} & Peat humification & $\begin{array}{l}\text { Proxy-climate (bog wetness), degree of peat } \\
\text { decomposition }\end{array}$ \\
\hline & Loss-on-Ignition & $\begin{array}{l}\text { Measure of organic component of peat. Used to identify } \\
\text { allochthonous input for site and land-use history }\end{array}$ \\
\hline & Bulk Density & $\begin{array}{l}\text { General peat parameter used to calculate accumulation } \\
\text { rate, compaction, aspects of carbon cycle }\end{array}$ \\
\hline & Magnetic susceptibility & $\begin{array}{l}\text { To indicate allochthonous components, core correlation, } \\
\text { pollution history }\end{array}$ \\
\hline & Carbon and $\mathrm{C} / \mathrm{N}$ ratios & Carbon cycling \\
\hline & Stable Isotopes & Proxy-climate studies \\
\hline & Dust Flux & Proxy-climate studies \\
\hline & Volcanic ash, tephra & Tephrostratigraphy, chronology \\
\hline \multirow{7}{*}{$\begin{array}{c}\text { Biological } \\
\text { Constituents }\end{array}$} & Pollen & Reconstruction of vegetational history: site and region \\
\hline & Plant Macrofossils & Site vegetational history (local), proxy-climate study \\
\hline & Charcoal & Fire history \\
\hline & Testate Amoeba & Hydrology, proxy-climate study \\
\hline & Stomatal Density (leaves) & Atmospheric $\mathrm{CO}_{2}$ \\
\hline & $\begin{array}{c}\text { Coleoptera, Chironomids, other } \\
\text { insects }\end{array}$ & Ecological conditions, climate proxies \\
\hline & Diatoms & Ecological conditions, climate proxies \\
\hline
\end{tabular}




\subsection{Plant macrofossil analysis in peat deposits}

Plant macrofossil analysis of peat deposits is used to reconstruct former plant assemblages and therefore palaeomoisture conditions on the bog surface through time. Along with palynology, it is one of the key methods to study peat deposits and gain palaeoclimatic reconstructions.

\subsubsection{What is plant macrofossil analysis?}

Holocene plant macrofossils are very well preserved in anaerobic environments that are maintained by high water-tables, such as peat bogs or lakes. Sequential deposition in those generally acid environments provides the basis for a highresolution temporal analysis (Birks, 2007; Mauquoy et al., 2011; Taylor et al., 2009). Quaternary plant macrofossils should however, be termed subfossils as they are rarely 'true fossils' in which the original organic material is substituted with inorganic materials (Birks, 2007; Blackford, 2000).

The main goal in plant macrofossil peat studies is the reconstruction and interpretation of past vegetation assemblages and environmental conditions by way of analysing the relative abundance of plant species in sedimentary deposits. Through identification of plant macrofossils from all layers of a peat bog, its climatic and vegetational history can be reconstructed. These reconstructions are based on the assumption of methodological uniformitarianism, which proposes that the presence of a taxon in the deposit is interpreted with regards to its modern-day ecological tolerances. In short, it assumes that the present is the key to the past (Birks \& Birks 1980). Thus, the requirements and preferred climatic conditions of modern-day plant species make it possible to infer past environmental conditions. Plant macrofossils preserved in peat bogs can therefore be used as indicator species for specific temperature and moisture conditions (Birks, 1981; Warner, 1988; Birks, 2007). Ombrotrophic bogs, such as Moanatuatua Bog, are especially suitable sources for plant macrofossil analysis as they are generally controlled by precipitation, which in turn controls the local water table and hence the vegetation composition on the bog surface (Mauquoy \& Barber, 1999; Blackford, 2000; Barber et al., 2004). 


\subsubsection{Methods: Quantification and Identification}

In the 1990s, the semi-quantitative quadrat and leaf-count macrofossil analysis (QLC; Barber et al., 1994) technique was developed and grew to be the standard method of analysis in peat macrofossil studies. This is particularly true for the analysis of Sphagnum (moss)-dominated raised mires in northern Europe. The main identifiable Sphagnum species can be aligned on a moisture gradient, thereby archiving palaeomoisture conditions on the bog surface at the time of deposition (Barber \& Charman, 2005). The QLC approach is divided into two stages of analysis: the first step provides quantitative estimates (volume percentages) of the major peat components and absolute numbers of fruits, seeds and other items that can be easily counted. In this step, the sample is poured into a petri-dish and assessed under low power magnification (generally x10) using a 10x10 square grid graticule in one eyepiece of a dissecting microscope. All peat components (such as roots, tissue remains, leaves of different species) are then estimated as percentages in each quadrat of the grid. A percentage estimation is necessary as these fragments can be rather fragmented and therefore hard to count accurately. The final result is the average of quadrat counts over 15 different random views per sub-sample (Barber et al., 1994). Other components, such as seeds, fruits, fern sporangia and charcoal particles are generally discrete and complete elements and are therefore assessed by counting (absolute numbers). In the second stage of analysis, a random selection of at least 100 Sphagnum leaves is mounted on microscope slides for further identification under higher magnification. This step allows estimating the proportion of each individual Sphagnum species in order to gain palaeomoisture information (Barber et al., 1994; Mauquoy \& Barber, 1999; Barber et al., 2004; Mauquoy et al., 2011). Identification of plant remains is based on the comparison with modern reference material. The QLC technique is regarded as the dominant source of palaeoclimate information from raised bogs in northern Europe (Barber \& Charman, 2005). It delivers a standard protocol for analysing plant macrofossils and therefore allows the comparison of different peat records. Its use in the Southern Hemisphere, especially New Zealand raised bogs, is however limited, most likely because of the paucity of work undertaken in these regions and the significant different composition of vegetation assemblages. Despite these drawbacks, due to the standardized guidelines and broad acceptance, the QLC approach delivers the basic outline for the new method of plant cuticle analysis proposed here (Chapter 3.3). 


\subsubsection{Advantages and limitations}

As just outlined, the QLC method is one of the key aspects of the first objective in this thesis (Chapter 1.2). For that reason and because plant cuticles are a type of plant macrofossil, it is necessary to delineate the advantages and limitations of plant macrofossil analysis. This also involves a comparison with palynology, as both methods are often employed alongside each other (Table 3).

Table 3: Summary of advantages, limitations and assumption of plant macrofossil analysis and palynology (compiled from Birks \& Birks, 2000; Birks, 2007)

\begin{tabular}{|c|c|c|}
\hline & $\begin{array}{l}\text { PLANT MACROFOSSIL } \\
\text { ANALYSIS }\end{array}$ & PALYNOLOGY \\
\hline Advantages & $\begin{array}{l}\text { - often identified to greater taxonomic } \\
\text { precision } \\
\text { - locally distributed from source } \\
\text { - can originate from taxa that produce } \\
\text { little/no pollen }\end{array}$ & $\begin{array}{l}\text { - } \quad \text { very resistant (most taxa) } \\
\text { - } \quad \text { produced in abundance: only small } \\
\text { sample size needed } \\
\text { - } \quad \text { widely distributed }\end{array}$ \\
\hline Limitations & $\begin{array}{l}\text { - not produced in abundance: large } \\
\text { sample sizes needed } \\
\text { - hard to quantify }\end{array}$ & $\begin{array}{l}\text { - limited taxonomic resolution } \\
\text { - } \text { some taxa have indistinguishable } \\
\text { pollen grains } \\
\text { - } \text { taxa have different preservation } \\
\text { potential and pollen production rates } \\
\text { (over- and/or under-representation) }\end{array}$ \\
\hline Assumption & \multicolumn{2}{|c|}{ methodological uniformitarianism } \\
\hline
\end{tabular}

One of the main advantages of plant macrofossil analysis is the size of the specimens found in the deposits. Many macrofossils can be identified to a lower taxonomic level (species) than pollen or spores, which can often only be distinguished to family or genus levels. Seeds and fruits especially can be identified to species level, and therefore a more accurate palaeoenvironmental reconstruction is possible (Mannion, 1986; Birks, 2001; Birks, 2007; Mauquoy et al., 2011). Macrofossils are generally rather heavy and thus not transported far from their parent plants on the bog surface. Consequently, they are very reliable in representing the local vegetation community, whereas pollen studies generally provide regional vegetation assemblages due to the capacity of pollen for widespread dispersal. Plant macrofossils have the advantage of representing the local flora without regional inputs, which makes the reconstruction of bog surface plant assemblages more straightforward (Grosse-Brauckmann, 1986; Mannion, 1986; Warner, 1988; Newnham et al., 1995; Birks, 2001; Birks, 2007; 
Mauquoy et al., 2011). Plant macrofossils can also provide insight into local vegetation assemblages in situations where the amount of pollen produced or preserved is low (Mannion, 1986; Birks, 2007).

One of the main limitations of plant macrofossil analysis is full and complete past plant assemblages cannot be reconstructed and compared with the modern flora at the site. This is due to the selective nature of decomposition in peatlands, which results in the possibility that subfossil plant remains in the peat bog may not correspond to the original vegetation on the bog surface (Mauquoy \& Yeloff, 2008). However, this limitation also applies to the preservation of some pollen taxa in peat deposits. For plant macrofossil analysis, large sample volumes need to be analysed in order to achieve accurate vegetation reconstructions due to the small number of macrofossil remains, such as fruits and seeds, produced in comparison with pollen (Birks \& Birks, 1980; Mannion, 1986). As outlined in Chapter 2.1.1, plant macrofossil analysis, along with all other biological proxies, is based on the assumption of methodological uniformitarianism. For this assumption to be valid, the relationship between plant species and the prevailing climate does not change over time. Plant macrofossil analysis is therefore dependent on the stability of these relationships, which are assumed to apply for at least the Holocene, the timeframe for this research (Birks, 1981; Blackford, 2000). A similar assumption relates to the identification of macrofossil remains and the expectation that identifiable features did not change drastically over time, which is also an acceptable assumption with respect to the desired time frame (Blackford, 2000). Additionally, it is assumed that vegetation assemblages are indicative of changing moisture conditions on the bog surface due to changing heights of the water-table which is itself sensitive to varying climatic patterns (Chapter 2.3.1).

In summary, plant macrofossil analysis allows identification to species level and represents the local, in-situ vegetation assemblage. An integrated analysis of plant macrofossils and pollen can therefore be used, where possible, to provide a detailed and highly accurate study of local and regional vegetation histories and palaeoenvironmental conditions. Accordingly, this study follows the same approach. Objective 2 offers a plant cuticle analysis and a separate study investigates the 
palynology for the same sequence (Ignacio Jara, VUW), the results of which are available to this study.

\subsection{Plant cuticles}

As mentioned, plant cuticles are a type of plant macrofossil and it is therefore expected that cuticles possess the same advantages, as well as limitations, as plant macrofossils. It would follow that the QLC scheme is therefore the analytical method of choice. However, Moanatuatua Bog and other raised bogs in New Zealand are not suitable for the application of this method due to their distinct vegetation assemblage (Chapter 2.3 and Chapter 2.4). This vegetation composition also complicates pollen identification as the two key plant species are hard to distinguish from one another. Thus, it is proposed that plant cuticle analysis can deliver a different approach to these problems.

\subsubsection{Functions of plant cuticles}

Plant cuticles cover the outer surface of most aerial parts of vascular land plants. They are defined as a thin $(<1 \mu \mathrm{m}$ to $15 \mu \mathrm{m})$, waxy and non-cellular membrane, which is formed by epidermal cells (Kerp \& Krings, 1999; Taylor, 1999; Pott \& Kerp, 2008; Taylor et al., 2009; Kerstiens, 2010). Based on their chemical composition, plant cuticles are divided into two parts (Fig. 1). The cuticular layer is mostly made up of the insoluble polymer matrix cutin, which functions as scaffolding (orange layer in Fig. 1). A mixture of different soluble organic compounds and lipids (waxes) make up the cuticle proper, the overlying layer (yellow layer in Fig. 1; Yeats \& Rose, 2013).

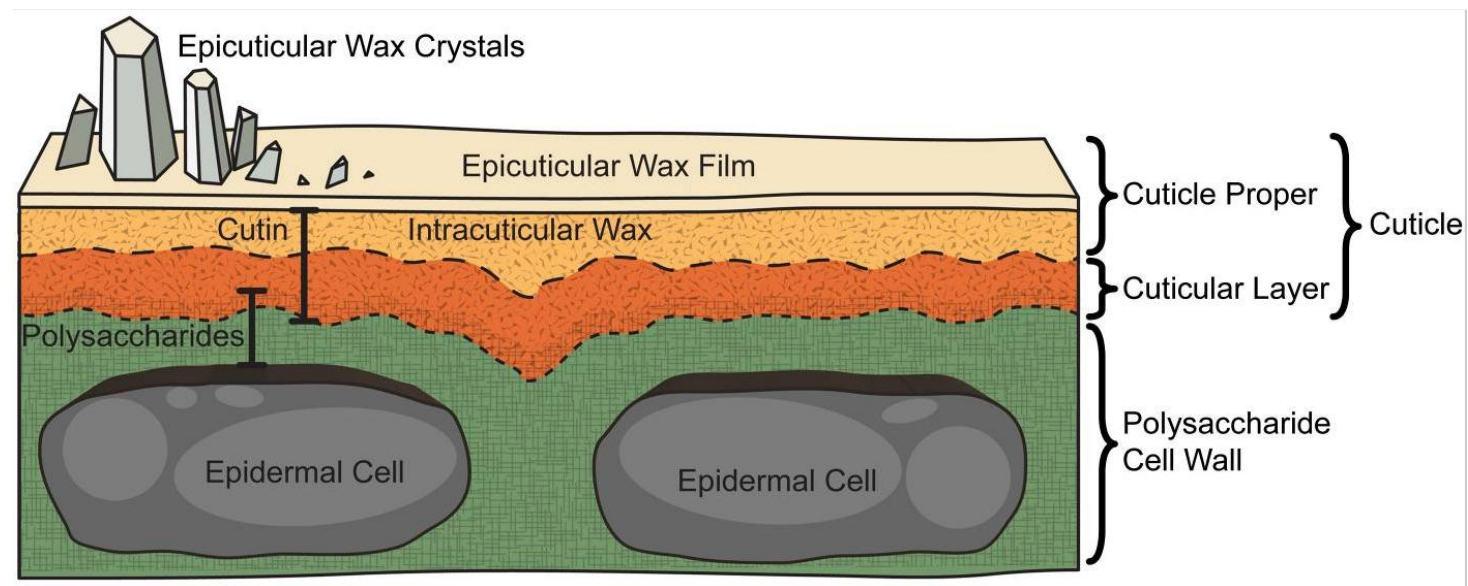

Figure 1: Plant cuticle structure (modified from Yeats \& Rose, 2013) 
Due to the abundance of waxes on their surface, plant cuticles are regarded as almost impermeable to water and gases, assisting the plant to retain water and to protect against drought and excessive evapotranspiration. However, stomata embedded in the epidermis and cuticle layer still allow gas exchange between the plant and its surroundings (Kerp, 1990; Taylor, 1999; Barclay, 2002; Pott \& Kerp, 2008; Yeats \& Rose, 2013). Due to their transparency, cuticles (as well as the epidermis) allow light to reach deeper cell layers for photosynthetic reactions (Barclay, 2002). The complex fatty substance cutin, as the main component of the cuticle proper, is indigestible by many pathogens, protecting the plant by preventing entry of bacteria or viruses (Taylor, 1999; Barclay, 2002; Kerstiens, 2010).

\subsubsection{Value of plant cuticles}

Based on this complex chemical composition, plant cuticles are regarded as being relatively resistant, thus showcasing a high fossilisation potential (Kerp, 1990; Taylor, 1999). This is especially true, if the sediments/rocks in which the cuticles are embedded, are not subject to high temperatures or oxidation (Pott \& Kerp, 2008). As a result, many fossil plant cuticles are well preserved in the geological record providing a significant source of palaeobotanical information (Taylor et al., 2009).

The major value of cuticular analysis lies in the fact that cuticles provide palaeoenvironmental data by preserving characteristic cell patterns and structures of the underlying epidermis (Dilcher, 1974; Kerp \& Krings, 1999; Taylor, 1999; Barclay et al., 2007; Pott \& Kerp, 2008). Most plant species have a unique epidermal cell pattern including the distribution of stomata, guard cells and other components such as hairs or oil glands, all of which can be imprinted on the cuticle. These features, together with the high fossilisation potential make plant cuticles a major resource for taxonomic and ecological studies, properties which are key considerations in this thesis (Kerp, 1990; Kerp \& Krings, 1999; Barclay et al., 2007). The primary focus of cuticular studies is the identification of fossil plant taxa by comparison of cuticles with modern reference material (Kerp, 1990). Additionally, cuticular analysis allows the correlation of dispersed plant fragments, therefore enabling the reconstruction of fossil plant assemblages similar to plant macrofossil analysis (Kerp, 1990; Kerp \& Krings, 1999; Taylor, 1999; Barclay et al., 2007; Pott \& Kerp, 2008). As in plant macrofossil analysis, cuticular analysis can be used as an 
additional source of information if palynology does not yield satisfactory results. For example, Bannister et al. (2012), used cuticular analysis to place fossil remains into the Lauraceae family and correlate them with modern species. This was necessary as most Lauracaea pollen have a low production rate and poor preservation potential. The majority of remains was therefore found as leaf fragments or dispersed cuticles. Identification of leaves was not reliable either as leaf morphology was found to be too variable to accurately identify different species. Cuticular analysis was thus also undertaken for precise identification of Lauraceae leaves to species level (Bannister et al., 2012).

The high identification potential of plant cuticles is a significant property regarding the second and third objective of this thesis as it is proposed that cuticle analysis enables an accurate and straight-forward identification of the two key plant species.

\subsubsection{Cuticular analysis}

The palaeobotanical significance of plant cuticles was recognised in the mid-1800s mainly by European palaeobotanists such as Wessel \& Weber (1855) and Bornemann (1856). Both studies are regarded as the first analysis to make use of epidermal patterns on cuticles from angiosperm and gymnosperm leaf remains, respectively (Dilcher, 1974; Kerp, 1990). These paved the way for the systematic analysis of fossil plant cuticles and recognized their significant taxonomic value. However, this only became recognized in the 1920s and 1930s as systematic studies and reviews of techniques were published (Dilcher, 1974; Kerp, 1990). Since then, cuticular analysis became a recognized tool for taxonomic identification with most of the work however, being done in central Europe (Dilcher, 1974).

Many fossil cuticle remains are found as compression fossils, where plants are buried in sediment and undergo physical compression. Cuticles can either be isolated from the sediment by bulk maceration or lifted off from the compression (Kerp \& Krings, 1999; Wooler, 2002; Pott \& Kerp, 2008; Taylor et al., 2009). Many studies use cuticle remains that are retained in pollen slides, highlighting the strong relationship with palynology (Wooler, 2002). Cuticles from peat deposits can be retrieved by maceration (chemically dissolving cuticle bearing material) of the peat and subsequently washing, sieving and picking the remaining plant tissue and cuticle 
remains (Wooler, 2002). This process is used as the basic preparation of peat samples with regard to objective 1 . However, cuticular analysis is generally not a standard tool in peat studies and its use is usually limited to taxonomic studies and occasional palaeoclimatological as well as palaeoenvironmental studies.

\subsection{Moanatuatua Bog: a raised restiad bog}

Moanatuatua Bog, a raised bog complex in the northern North Island of New Zealand, is the field site for this research. It is dominated by two main species of the Southern Hemisphere family of the Restionaceae (restiad species), which largely accounts for the bogs' distinct features, floristic adaptations and successional patterns.

\subsubsection{Focus: Raised bogs}

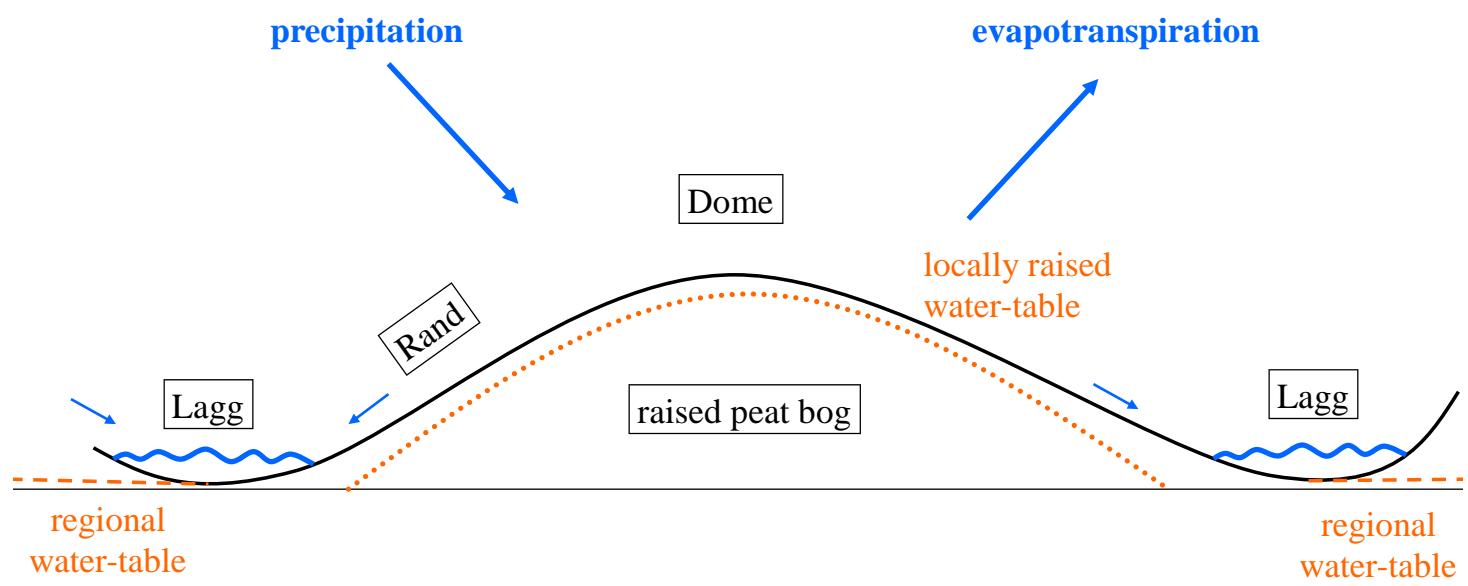

Figure 2: Conceptual cross-sectional view of an ombrotrophic peatland

The development of raised bogs involves the gradual upward movement of the bog surface due to peat accumulation (ombrotrophication) in flat basins or alluvial terraces (Rydin \& Jeglum, 2006; Belyea, 2009). Essential elements for the initiation of ombrotrophication include impeded drainage conditions, saturated ground surfaces and subsequently, the isolation from any flowing water that is nutrient-rich and highly oxygenated. The presence of a highly water-retentive vegetation assemblage is also a requirement. Resulting acid conditions in the bog will delay decomposition and oxygen-depleted conditions in the wet ground will obstruct the work of fungi and bacteria in fully decomposing organic matter. Under these conditions, it is therefore possible for peat to rapidly accumulate and gradually form a raised surface. Eventually the accumulated peat will give rise to some colonising plant species, 
which in turn will also speed up the accumulation process due to the surplus of organic matter. In this way, gradual isolation of the bog surface from the surrounding terrain occurs and the system becomes dependent on rainwater for nutrient and water supply. The colonization of vegetation adapted to those nutrient-poor and acid conditions thus marks the transition to a bog. Development of a raised bog results in greater nutrient and oxygen concentrations around the perimeter of the bog (lagg) due to runoff and groundwater influence, which, in turn, reduces peat accumulation rates there (Fig. 2). In the centre of the bog, peat accumulation, however, is rapid and a dome forms, which slopes to the margins (rand) (Birks \& Birks, 1980). As the dome is elevated above the surrounding terrain, the water table of the mire system occupies a lens within the elevated bog (Campbell, 1975; Shearer, 1997). The resulting raised peat bogs are rich in organic matter, highly acidic and decomposition rates are minimal, which allows for plant material to be well preserved (Campbell, 1975; Shearer, 1997; Johnson \& Gerbeaux, 2004; Rydin \& Jeglum, 2006; Belyea, 2009).

\subsubsection{Moanatuatua Bog: Introduction}
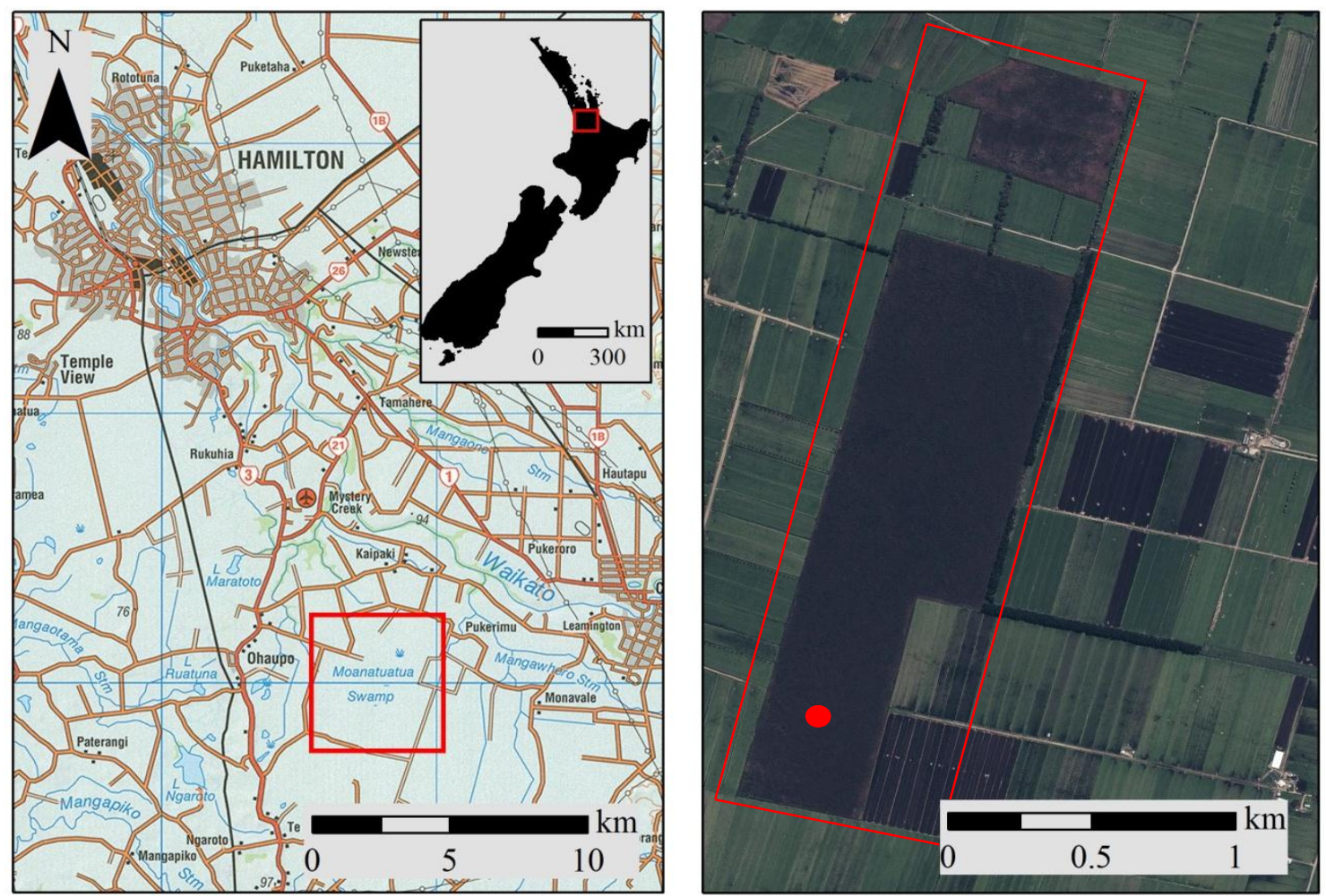

Figure 3: Location of Moanatuatua Bog in the Waikato Region (left) and approximate location of cores on southern part of southern remnant (right ) (source: KiwImage (satellite image) and LINZ (topographic map)) 
Moanatuatua $\operatorname{Bog}\left(37^{\circ} 58^{\prime} \mathrm{S}, 175^{\circ} 72^{\prime} \mathrm{E}\right.$; Fig. 3) is one of 9 restiad bogs still dominated by native vegetation in the central Waikato Region. It is located $17 \mathrm{~km}$ southeast of Hamilton in the Hamilton Basin, an oval-shaped depression that stretches over $80 \mathrm{~km}$ in north-south direction and over $40 \mathrm{~km}$ in the east-west direction (Selby \& Lowe, 1992; Clarkson, 1997; Clarkson et al., 2004). The bog itself was once rather more extensive and covered an area of approximately $75 \mathrm{~km}^{2}$ (Clarkson, 1997) with a maximum peat thickness of approximately $15 \mathrm{~m}$ (Clarkson, 1997; Shearer, 1997). During the early 1900s, however, drainage and conversion to farmland significantly reduced the size of the bog. Now only two small and isolated remnants of the former bog are left, with a total size of $1.2 \mathrm{~km}^{2}$ (Clarkson, 1997; Shearer, 1997; Thompson et al., 1999; Moore \& Shearer, 2003; Clarkson et al., 2004; Campbell et al., 2014). The bigger remnant is protected as the Moanatuatua Scientific Reserve $\left(\sim 1.1 \mathrm{~km}^{2}\right.$; rectangular shape; east-to-west width of $\sim 700 \mathrm{~m}$, north-to-south length of 2000 m; Thompson et al., 1999; Campbell et al., 2014). It was established in order to preserve a representative example of the original bog ecosystem and protect unique plant assemblages in a threatened ecosystem (Clarkson et al., 1999; Thompson et al., 1999).

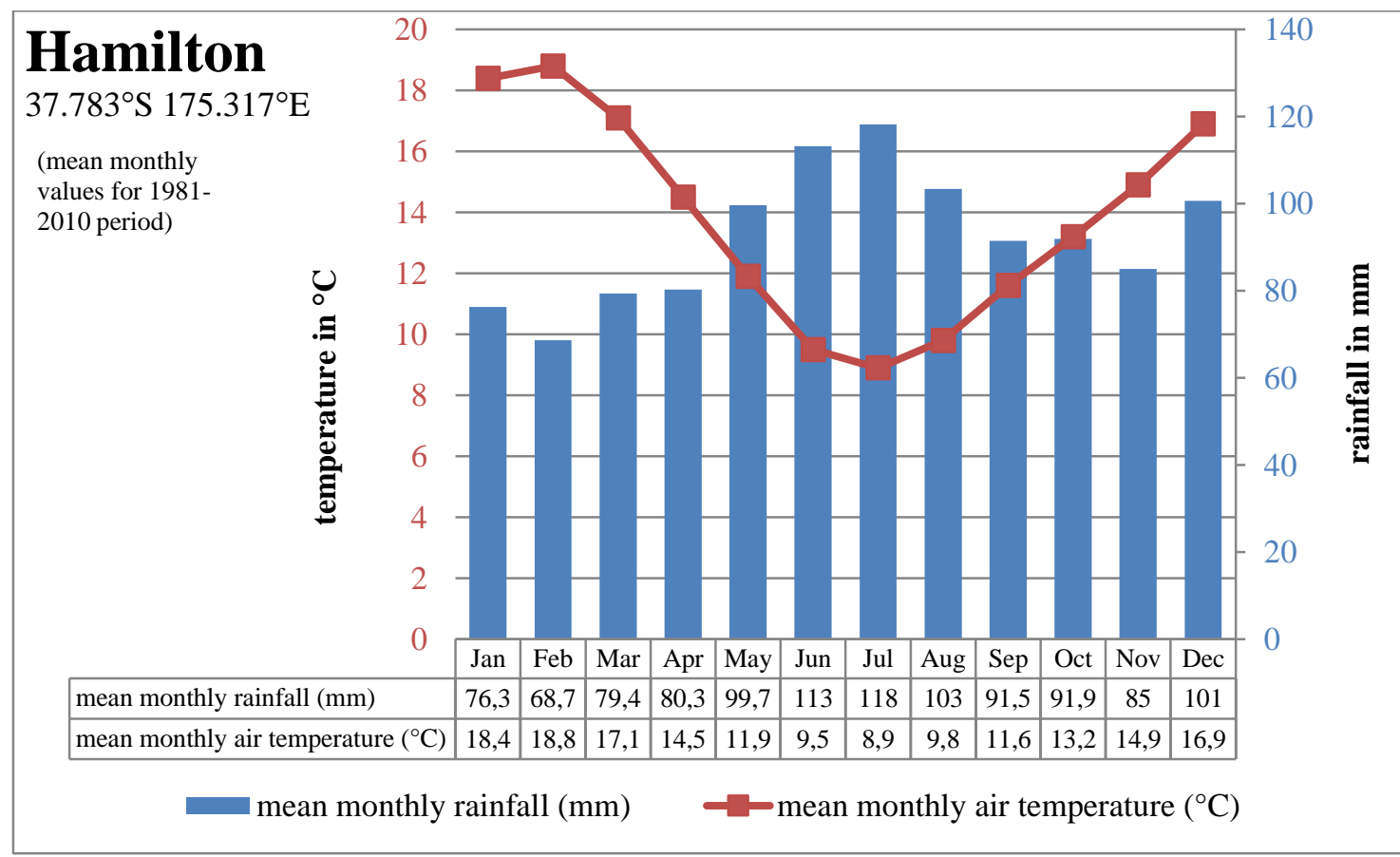

Figure 4: Mean monthly rainfall (in $\mathrm{mm}$ ) and mean monthly air temperature (in ${ }^{\circ} \mathrm{C}$ ) values for 1981-2010 period (data compiled from www. niwa.co.nz, 2014) 
Interestingly, the climate in the central Waikato Region is not regarded as being especially suitable for the growth and development of large raised bogs. The region is characterised by having warm and dry summers with rather high evapotranspiration rates (Fig. 4). Thus, it must be the special xeromorphic properties of the main peat-forming plant species that help develop raised bogs and maintain them by storing water and reducing evapotranspiration rates (Clarkson et al., 2004; McGlone, 2009; Chapter 2.4).

\subsubsection{Development of raised bogs in the Waikato Region}

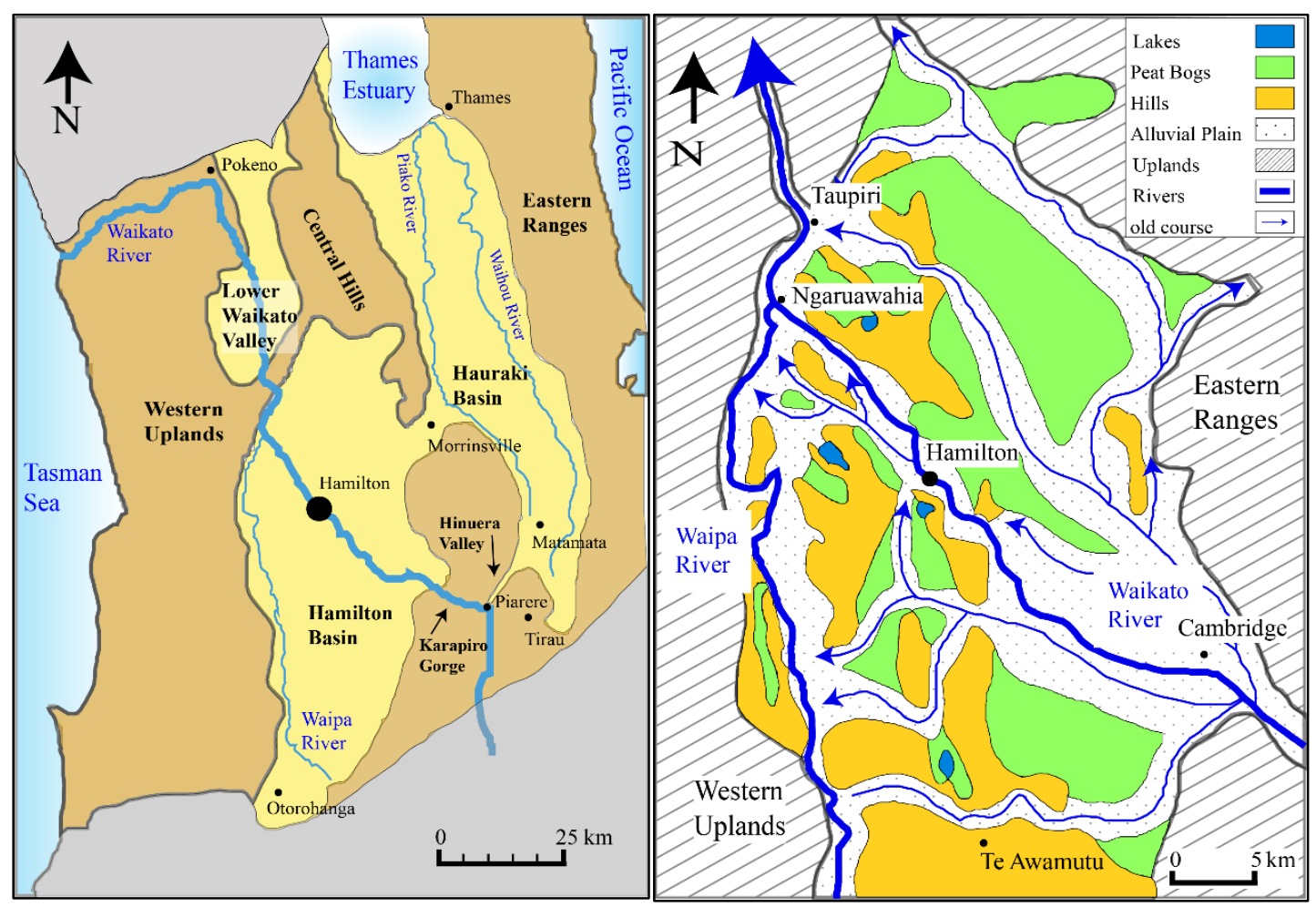

Figure 5 (left): Landscape pattern of the Waikato Region (modified from McCraw, 2002)

Figure 6 (right): The most prominent abandoned courses of the Waikato River in the Hamilton Basin (modified from McCraw, 2002)

The Waikato Region (Fig. 5) is characterized by three parallel blocks of highlands (Eastern Ranges, Central Hills and Western Uplands) which are separated by two basins (Hamilton Basin and Hauraki Basin), a pattern developed after a series of parallel faulting and differential uplift (McCraw, 2002). Until approximately 22000 cal yr ago, the Waikato River regularly changed course and flowed either through the Hinuera Valley to the Thames Estuary or through the Karapiro Gorge and the Hamilton Basin to the Tasman Sea (Fig. 6). Both basins, the Hauraki and the Hamilton Basin, therefore consecutively received alluvium from the meandering Waikato River. Around 22000 cal yr ago, the Waikato River last changed course and 
returned to the Hamilton Basin, where it became entrenched in its modern northwestward course around 17000 cal yr ago (McCraw, 2002; Manville \& Wilson, 2004). Small streams that were draining into the Hamilton Basin were blocked by thick alluvium and, as a result, became ponded, which led to the development of small and isolated bogs in poorly drained, low-lying areas. Due to the confinement of the Waikato River, the surface of the Hamilton Basin became stable and encouraged the establishment of water-tolerant plant species between the abandoned river courses. The further expansion of the major geomorphologic features of the Waikato Region, such as peat bogs, swamps, alluvial plains and small lakes was largely initiated by warmer and wetter postglacial climatic conditions (Lowe, 2010). As a result, the rise in regional water-tables eventually led to the coalescence and development of the extensive raised peat bogs of the Waikato Region (McCraw, 2002; Lowe, 2010). Based on radiocarbon dates of the deepest peat, accumulation at Moanatuatua Bog started approximately 15500 cal yr BP (Hogg et al., 1987) when sedges started to colonize in poorly drained hollows. This reflects the minerogenic fen stage at the start of the successional pathway that eventually leads to bogconditions (Green \& Lowe, 1985; Lowe, 1988; Selby \& Lowe, 1992; Clarkson, 1997; Shearer, 1997; Clarkson et al., 1999; De Lange et al., 1999; Moore \& Shearer, 2003).

\subsection{Vegetation}

As mentioned in the previous section, climatic conditions in the Waikato Region are generally not suitable for the growth and development of raised bogs. A special assemblage of plant species is therefore necessary to initiate the formation and continued persistence of peat bogs in the central North Island of New Zealand (Johnson \& Gerbeaux, 2004). Paradoxically, the Restionaceae family's main centre of diversity is located in the dry plains of South Africa and Australia. A very limited number of species can also be found in southeast tropical Africa, Southeast Asia and New Zealand. In New Zealand, the two main species and peat formers in bogs north of $38^{\circ} \mathrm{S}$ latitude are Empodisma robustum (lesser wire rush, henceforth Empodisma) and Sporadanthus ferrugineus (greater wire rush, henceforth Sporadanthus). Both are confined to this particular region and therefore seem to be constrained by specific temperature and rainfall limits (Campbell, 1975; Newnham et al., 1995; Clarkson et al., 1999, Clarkson et al., 2004). Empodisma especially, as the dominant peat-former, 
has developed adaptations to conserve water, which allows raised bogs to develop in an environment that is characterized by seasonal water deficits (Clarkson, 2002).

\subsubsection{Restionaceae}

Restiad bogs in the Waikato Region are characterized by an upper tier of up to $2.8 \mathrm{~m}$ tall Sporadanthus plants that stands above a dense understory of spread-out Empodisma (Fig. 7; Rydin \& Jeglum, 2006). A feature common to restiads is the occurrence of hairy cluster roots. These represent an adaptation to nutrient poor substrates, as their densely matted roots are able to take up rare nutrients (McGlone, 2009).

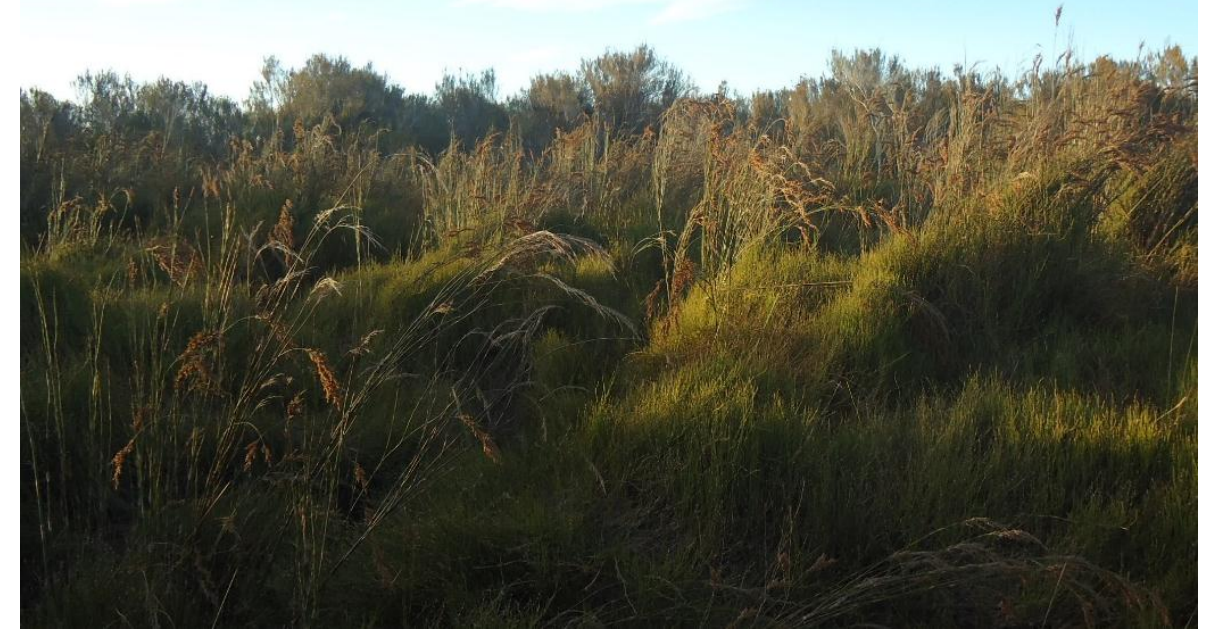

Figure 7: Moanatuatua Bog with tall Sporadanthus and smaller Empodisma plants (photo by Ignacio Jara, VUW)

Sporadanthus ferrugineus

Until 1999 it was believed that Sporadanthus traversii was endemic to both mainland New Zealand raised bogs north of $38^{\circ} \mathrm{S}$ latitude and the Chatham Islands (Campbell, 1975; Selby \& Lowe, 1992; Newnham et al., 1995). However, a comparison of plants from the North Island of New Zealand with specimens from the Chatham Islands showed that they are actually different species (de Lange et al., 1999). The plants from the peat bogs of the northern North Island were described as more robust than their southern counterparts and subsequently named Sporadanthus ferrugineus. It is also described as a more robust restiad than Empodisma and therefore forms a climax community, which represents full oligotrophic conditions (Newnham et al., 1995; Thompson et al., 1999; Rydin \& Jeglum, 2006). On average, the stout and $\mathrm{reed} / \mathrm{cane-like} \mathrm{stems} \mathrm{of} \mathrm{Sporadanthus} \mathrm{can} \mathrm{be} \mathrm{between} 1.2$ and $1.8 \mathrm{~m}$ tall (Campbell, 
1975; Selby \& Lowe, 1992) but at Moanatuatua they can reach heights of up to $2.8 \mathrm{~m}$ (Campbell et al., 2014). The sturdy stems (diameter $0.2-1.5 \mathrm{~cm}$ ) grow in dense clumps with a diameter of up to $1.5 \mathrm{~m}$ (Thompson et al., 1999). Due to their height, the stems are able to break the force of the wind as well as provide shade from the sun, therefore sheltering smaller plants. As a result, evapotranspiration rates from the bog surface are significantly reduced (Campbell, 1964; Campbell, 1975; Newnham et al., 1995). Sporadanthus possesses aerating tissue in its roots and rhizomes as well as in the bases of its stems. This feature allows for survival under waterlogged conditions (Campbell, 1964). Below the bog surface, the stout, horizontal rhizomes build a dense and interweaving network. This branching network creates a scaffolding platform, which is upheld and anchored by long, vertical stilt-like roots. The platform in turn supports the weight of the remaining bog vegetation (Campbell, 1964; Campbell, 1975; Newnham et al., 1995). Although Sporadanthus is considered to be an important peat former in restiad bogs, Empodisma is better adapted to proliferate in the harsh conditions of a raised bog. Furthermore, Sporadanthus is not fire resistant and has to re-establish on the bog surface after fire. It is however a late successional climax species, establishing after an initial Empodisma phase and therefore is tolerant of very low nutrient conditions due to its high nutrient-use efficiency (Rydin \& Jeglum, 2006).

\section{Empodisma robustum}

The genus Empodisma comprises three species that occur in wetlands across New Zealand and Australia: Empodisma gracillimum, which is restricted to south-western Australia, Empodisma minus which can be found in Tasmania, eastern Australia and New Zealand and Empodisma robustum, which is limited to peatlands north of $38^{\circ} \mathrm{S}$ latitude on the North Island of New Zealand (Wagstaff \& Clarkson, 2012). E. robustum was only described in 2012, when Wagstaff \& Clarkson (2012) analysed DNA from 15 individual Empodisma samples. Results revealed that a species exists that is genetically distinct from E. gracillimum and E. minus. It was given the name E. robustum to reflect its more robust growth pattern than E. minus (Wagstaff \& Clarkson, 2012). E. robustum is regarded as the main peat former on Waikato restiad bogs, which is mainly due to its establishment of copious masses of fine roots (cluster roots), which arise from an erect rhizome just below the bog surface. The roots grow horizontally and also develop prolific masses of fine roots. These in turn 
grow erect above the surface and establish a thick and intertwined mat of white to pink roots. All roots are covered by root hairs, which can be up to $1 \mathrm{~mm}$ in length (Campbell, 1964; Campbell, 1975; Agnew et al., 1993). These so-called cluster roots form the bulk of the peat as the roots engulf smaller plants, litter and stem bases on the bog surface and bind them into the peat. They are also highly efficient at absorbing water and nutrients (Clarkson et al., 2004) from precipitation and creating acid conditions. In general, the cluster roots of Empodisma are believed to retain water like a sponge at the amount of up to 15 times their dry weight (Agnew et al., 1993; Rydin \& Jeglum, 2006; Wagstaff \& Clarkson, 2012). The wiry stems of Empodisma can reach heights of up to $0.6 \mathrm{~m}$ in the open but it can form a dense canopy up to $1.2 \mathrm{~m}$ amongst the taller Sporadanthus stems. They can range in thickness from $1-3 \mathrm{~mm}$ and often grow so dense that no light penetrates the bog surface beneath (Campbell, 1975; Thompson et al., 1999). Additionally, as the canopy is mostly made up of dead stem and litter material, it minimises evapotranspiration from the peat substrate (Thompson et al., 1999).

\subsubsection{Vegetation succession in a peat bog}

Succession is defined as a directional change over time in the composition and assemblage of plant species in an ecosystem, including associated faunal changes as well as changes in other habitat features, such as nutrient status or substrate conditions. Succession can be divided into two main sub-categories: primary and secondary succession. Primary succession describes the establishment of vegetation on substrate that was previously free of any vegetation. Secondary succession takes place on sites where vegetation was present before but experienced some kind of disturbance, such as fire, flooding, drought or human activities that set the vegetation back to an earlier stage of development (Rydin \& Jeglum, 2006). In peatlands, both succession pathways advance towards decreasing species richness, increasing acidity, decreasing fertility and decreasing base saturation. The reason for this progress lies in the control of water and nutrient supply on the succession as the ecosystem develops from a minerotrophic mire to an ombrotrophic raised bog (De Lange, 1989; Clarkson, 1997; Clarkson et al., 2004; Rydin \& Jeglum, 2006). In this thesis, primary succession at Moanatuatua Bog will be analysed as part of objective two whereas secondary succession (Chapter 2.5) will be the focus of objective three. 
Primary succession of raised bogs can be described in three phases (Table 4; Clarkson, 1997; Clarkson et al., 1999; Clarkson, 2002; Clarkson et al., 2004).

Table 4: Bog vegetation succession through time and main moisture indicator plant species at Moanatuatua Bog (modified from Hazell, 2004 and compiled from Campbell et al., 1973; Clarkson, 2002; Clarkson et al., 2004)

\begin{tabular}{|c|c|c|c|c|}
\hline $\begin{array}{c}\text { NUTRIENT } \\
\text { LEVEL }\end{array}$ & AGE & DOMINANT SPECIES & $\begin{array}{l}\text { MOISTURE } \\
\text { INDICATOR }\end{array}$ & PHASE \\
\hline $\begin{array}{l}\text { High } \\
\text { minerotrophic }\end{array}$ & young & $\begin{array}{c}\text { Leptospermum scoparium } \\
\text { sedges }\end{array}$ & Very dry & 1 \\
\hline Medium & & Gleichenia dicarpa & Dry & \\
\hline \multirow{2}{*}{$\begin{array}{c}\text { Low } \\
\text { oligotrophic }\end{array}$} & & Empodisma robustum & \multirow{2}{*}{ Wet } & 2 \\
\hline & old & Sporadanthus ferrugineus & & 3 \\
\hline
\end{tabular}

The initial phase is dominated by sedges as well as Leptospermum scoparium (manuka, henceforth Leptospermum) shrubs that are tolerant of dry conditions. Depending on the nutrient and water input from the groundwater and the disturbance history of the site, this phase can last from hundreds to several thousands of years. As the sedge peat from this plant association builds up, Gleichenia dicarpa (tangle fern, henceforth Gleichenia) can establish as fern rafts, raising the surface of the minerotrophic mire slightly above the water-table. After that, Empodisma is able to establish on those rafts at the expense of the more nutrient-demanding sedges. Restiad peat then starts to develop, which raises the bog surface above the influence of the groundwater. Conditions become mesotrophic and subsequently ombrotrophic as plant associations are dependent on rainfall for nutrients. Finally, oligotrophic bogs are characterized by the establishment of the second restiad, Sporadanthus, which eventually dominates the bog surface.

\subsubsection{Modern vegetation pattern}

The following table (Table 5) provides an overview of the main plant species found on restiad bogs in the Waikato Region. It is divided into plants forming the upper tier, the lower tier and minor plant species of the vegetation assemblage. 
Table 5: Major modern plant species of restiad bogs in the Waikato Region (compiled from Clarkson, 1997; Hazell, 2004; Clarkson et al., 2007)

\begin{tabular}{|c|c|c|c|}
\hline & $\begin{array}{l}\text { LATINA } \\
\text { BINOMINAL }\end{array}$ & FAMILY & COMMON NAME \\
\hline \multirow{4}{*}{ Upper tier } & Empodisma robustum & Restionaceae & (Lesser) wire rush \\
\hline & Epacris pauciflora & Epacridaceae & $\begin{array}{l}\text { Bog epacris; tumingi } \\
\text { Heather }\end{array}$ \\
\hline & $\begin{array}{l}\text { Leptospermum } \\
\text { scoparium }\end{array}$ & Myrtaceae & Manuka; tea tree \\
\hline & $\begin{array}{l}\text { Sporadanthus } \\
\text { ferrugineus }\end{array}$ & Restionaceae & $\begin{array}{l}\text { Greater wire rush; } \\
\text { cane rush }\end{array}$ \\
\hline \multirow{6}{*}{ Lower tier } & Baumea teretifolia & Cyperaceae & Pakihi rush \\
\hline & $\begin{array}{l}\text { Campylopus } \\
\text { acuminatus var. kirkii }\end{array}$ & Dicranaceae & -- \\
\hline & Gleichenia dicarpa & Gleicheniaceae & $\begin{array}{l}\text { Swamp/umbrella/tangle } \\
\text { fern; waewae kotuku }\end{array}$ \\
\hline & $\begin{array}{l}\text { Goebelobryum } \\
\text { Unguiculatum }\end{array}$ & Southbyaceae & -- \\
\hline & Riccardia crassa & Aneuraceae & -- \\
\hline & Schoenus brevifolius & Cyperaceae & Short-leaf bog rush \\
\hline \multirow{14}{*}{ Minor species } & Anzybas carsei & Orchidaceae & Swamp helmet orchid \\
\hline & Baumea arthrophylla & Cyperaceae & -- \\
\hline & Baumea rubiginosa & Cyperaceae & Twig rush \\
\hline & Coprosma tenuicaulis & Rubiaceae & $\begin{array}{l}\text { Hukihuki; swamp } \\
\text { Coprosma }\end{array}$ \\
\hline & $\begin{array}{l}\text { Dracophyllum } \\
\text { lessonianum }\end{array}$ & Epacridaceae & -- \\
\hline & $\begin{array}{l}\text { Dracophyllum } \\
\text { scoparium }\end{array}$ & Epacridaceae & Swamp heath \\
\hline & Drosera binate & Droseraceae & Forked sundew \\
\hline & Lycopodiella lateralis & Lycopodiaceae & Club moss \\
\hline & $\begin{array}{l}\text { Lycopodium } \\
\text { serpentinum } \\
\text { (Lycopodiella } \\
\text { serpentina) }\end{array}$ & Lycopodiaceae & Bog club moss \\
\hline & Phormium tenax & Agavaceae & $\begin{array}{l}\text { New Zealand flax; } \\
\text { Harakeke }\end{array}$ \\
\hline & Salix cinerea & Salicaceae & Grey willow; sallow \\
\hline & Salix fragilis & Salicaceae & Crack willow \\
\hline & Sphagnum cristatum & Sphagnaceae & Moss \\
\hline & Utricularia laterifolia & Lentibulariaceae & Bladderwort \\
\hline
\end{tabular}




\subsection{Fire events on the bog surface}

By analysing plant remains from the peat deposit, a fire history for the bog and the surrounding landscape as well as the secondary successional pathway can be reconstructed.

\subsubsection{Introduction: Fires on wetlands}

Charman et al. (2009) concludes that summer precipitation is the major control of bog development in the Northern Hemisphere, which is by implication, based on the strong drawdown of water-tables in summer months. As a result, bog surfaces can dry out sufficiently in the summer months and carry enough combustible organic material to support fires. In the Waikato Region, bogs also experience dry summers (Chapter 2.3.2) and summer bog fires have been observed in recent decades (Stanway \& Clarkson, 1994) making them suitable for investigating palaeofires and their relationship to climate. The physical attributes of raised bogs are also favourable for the onset of fires on the bog surface during dry months. The dense and mostly uniform vegetation cover and the rather flat, gently sloping topography result in the lack of natural fire breaks that could stop fires from spreading across the grounds (McGlone, 2009; Perry et al., 2014). Furthermore, the thick Empodisma canopy successfully restricts excessive evapotranspiration rates and creates a rather warm and dry surface ("wet desert") conducive for the start of fires (Campbell \& Williamson, 1997).

Fossil charcoal found in peat deposits supplies a record of the occurrence of fires either on the bog surface or in the region (Taylor et al., 2009). By lysing the abundance of charcoal particles throughout a peat sequence (just like plant macrofossils) a fire history of the site can be reconstructed (Mooney \& Tinner, 2011). In general terms, the size of the charcoal particles determines the locality of the producing fire. Microscopic charcoal particles $(<100 \mu \mathrm{m}$ in length) are readily quantified in conjunction with palynology using a microscope. Macroscopic charcoal particles $(>100 \mu \mathrm{m}$ in length) are usually quantified by isolation from other material using wet sieving, for example in conjunction with plant macrofossil analysis. Due to the size of macroscopic charcoal, it travels a much shorter distance than microscopic charcoal and therefore represents a record of local fires rather than distant regional burning. Macroscopic charcoal therefore can provide a better defined and more 
precise fire history that is capable of recording in-situ events (Mooney et al., 2011; Mooney \& Tinner, 2011). Together, the abundance of microscopic and macroscopic charcoal in a record thus indicates the existence of fires at the regional and local scale over time (McGlone et al., 1984; Scott \& Jones, 1991; Perry et al., 2014).

\subsubsection{Vegetation response}

Fires on the bog surface have substantial effects on the vegetation community. On the bog surface, fires remove vegetation, destroying the canopy and litter layer, which adds nutrients to the bog. As a result, fires set the bog development back to an earlier stage towards the high-fertility end of the successional sequence. Secondary succession, the vegetation recovery process, then depends on the fire regime, the intensity and frequency of fires (Clarkson, 1997; Rydin \& Jeglum, 2006; Sharitz \& Pennings, 2006; McGlone, 2009).

Only few studies have been undertaken on the recovery of wetland vegetation after fires in New Zealand. From the studies that have looked at the response of the local bog vegetation to fire events, some general trends and recovery processes can be identified (e.g. Mark \& Smith, 1975; Timmins, 1992; Clarkson, 1997; McQueen \& Forester, 2000; Johnson, 2001; Norton \& de Lange, 2003). A clear distinction between plant species can be made on the basis of their recovery process (Table 6). Plant species that recover via regenerative organs are called endurers. The mature plants above-ground cannot survive fires, but they can resprout from protected below-ground parts such as rhizomes (underground stem that is capable of producing the root system). Thus, rhizomatous plants, such as sedges and Gleichenia are in general the species with the most rapid recovery on burnt bog surfaces in New Zealand (Timmins, 1992). Although, both Empodisma and Sporadanthus are rhizomatous species, they are not regarded as species that re-establish very quickly. In the case of Empodisma, this might be due to the fact that its roots grow horizontally just beneath the surface and are therefore susceptible to damage by fire. Roots of Sporadanthus, on the other hand, grow horizontally several centimetres below the surface and should be protected from surface fires. However, Sporadanthus seems to be especially susceptible to fire and takes a long time before it re-establishes on burnt surfaces. The reason for this behaviour might lie in the successional pathway, as discussed earlier (Chapter 2.4.2) and the need for 
Empodisma to be the first dominant restiad species. Plant species that recover via seed are called invaders. Seeds most commonly originate from mature plants nearby (dispersed via wind or birds) or from fruits that have survived the fire (Clarkson, 1997; McQueen \& Forester, 2000; Johnson, 2001; Norton \& De Lange, 2003). Empodisma, Sporadanthus and Leptospermum are all invader species as they are typically killed by fire and have to establish anew.

Table 6: Summary of fire-adaptations of main bog plant species (compiled from Clarkson, 1997; Johnson, 2001; Norton \& de Lange, 2003; Perry et al., 2014; Timmins, 1992)

\begin{tabular}{|l|l|}
\hline \multicolumn{2}{|c|}{ Recovery via regenerative organs (endurers: resprout from protected plant parts) } \\
\hline $\begin{array}{l}\text { Sedges (Schoenus spp. } \\
\text { and Baumea spp.) }\end{array}$ & $\begin{array}{l}\text { Tough, thick rhizome } \\
\text { Rhizome grows horizontally several cm below surface }\end{array}$ \\
\hline Gleichenia dicarpa & $\begin{array}{l}\text { Rhizomes are more slender, wiry } \\
\text { Rhizome grows at or just beneath bog surface: susceptible to damage }\end{array}$ \\
\hline \multicolumn{2}{|c|}{ Recovery via seed (invaders: re-establishment from seed) } \\
\hline $\begin{array}{l}\text { Empodisma robustum } \\
\text { ferrugineus }\end{array}$ & $\begin{array}{l}\text { Large erect rhizome, 5mm in diameter } \\
\text { Roots grow horizontally just beneath bog surface: susceptible to damage }\end{array}$ \\
\hline $\begin{array}{l}\text { Leptospermum } \\
\text { scoparium }\end{array}$ & $\begin{array}{l}\text { Large rhizomes, 10mm thick } \\
\text { Roots grow horizontally several cm below bog surface } \\
\text { End-member of successional pathway }\end{array}$ \\
\hline
\end{tabular}

In 1972, a fire burnt the uppermost layers of the peat deposit and destroyed all vegetation above-ground ('cool fire) at Moanatuatua Bog (Clarkson, 1997). As the fire occurred during spring, the water-table was rather high and protected the bog from the destruction of deeper peat layers. Therefore, many plants with underground growing tips survived the fire and initiated the rapid recovery of the canopy. Sedges made the quickest recovery by resprouting from surviving rhizomes, subsequently dominating the vegetation assemblage in the first 2-3 years after the fire event. Sporadanthus and Empodisma both were killed by the fire and had to establish anew by resprouting from seeds. Empodisma became dominant after 4 years, whereas Sporadanthus only became established after 5 years. In total it took 11.5 years for Sporadanthus to reach pre-fire height and cover conditions and another 10 years for it to become the dominant species (Clarkson, 1997). In conclusion, bog vegetation responds and re-establishes a canopy cover very quickly on the geologic timescale (less than 10 years). However, it may take more time and no further disturbance to 
reach pre-fire assemblages, cover values and especially plant heights. The time taken for the recovery of the vegetation after a fire event is the key consideration for the third objective in this thesis (Chapter 1.2). Three of the presumably biggest and largest fire events in $>10000$ years are selected for analysis. The impact the fire had on the bog vegetation will therefore have been much greater than any fires observed in recent decades making comparisons with modern studies harder. However, by implication, recovery times of destroyed vegetation on the bog surface could have been much longer as well, making analytical observations easier. 


\section{METHODOLOGY}

The following chapter will provide information about the retrieved cores from Moanatuatua Bog. This includes details about the age-depth model, which was established via radiocarbon dating. As a next step, this chapter will outline the different stages of analysis in order to answer the three objectives proposed in this research. First, the sampling strategy for both scales of resolution will be explained in detail. The development of a new methodology based on adapted and already established techniques will be the next focus. Before summarising all methodological stages in this thesis, the steps undertaken for bulk density and loss-on-ignition analysis will be outlined.

\subsection{Field work and Material}

Two cores from the southern margin of Moanatuatua Bog (Chapter 2.3) were taken in November 2012 by Ignacio Jara (VUW), Rewi Newnham (VUW), Matt Ryan (VUW), David Lowe (University of Waikato) and Courtney Foster (University of Waikato). During the coring process and while in storage, compression or loss of material can occur. Hence, two consecutive cores were taken from Moanatuatua Bog at $37^{\circ} 55^{\prime} 45.1^{\prime \prime} \mathrm{S} 175^{\circ} 22^{\prime} 13.2^{\prime \prime} \mathrm{E}$. They are named 1201 and 1202 throughout this thesis (12 for year 2012, 01/02 for core 1 and 2). After extracting the cores, they were wrapped in plastic wrap and labelled with drive number and an indicator to locate the top of the drive. They were then placed in PVC tubes and stored at about $3^{\circ} \mathrm{C}$ in a cold store at VUW.

Depending on the nature and compaction of material, either a Livingstone piston corer or a Russian corer was used. Core 1202 was taken with a Russian corer and consists of fourteen $50-\mathrm{cm}$ long drives. Material was extracted until an orange tephra layer was reached. The first $1 \mathrm{~m}$ of core 1201 was taken with a Russian corer and is made up of two 50-cm long drives. Subsequently, six meters were taken with a Livingstone piston corer in six 1-m long drives. A Russian corer was used to sample the last $1.5 \mathrm{~m}$ of core 1201 in three $50-\mathrm{cm}$ long drives until a grey tephra layer was reached (pers. comm. Ignacio Jara, VUW). Sampling was undertaken on both cores 
and therefore it was necessary to establish a depth correlation between the two cores, which is based on the stratigraphic location of charcoal and tephra layers that were visible at the time of extraction (pers. comm. Ignacio Jara, VUW). Each drive was 50 $\mathrm{cm}$ long and depths were calculated accordingly, including small depth corrections due to compression of some drives. Figure eight shows the composite core, which displays the drives of each core that were used for sampling. It consists of all 14 drives of core 1202 and the last two drives of core 1201 (Fig. 8).

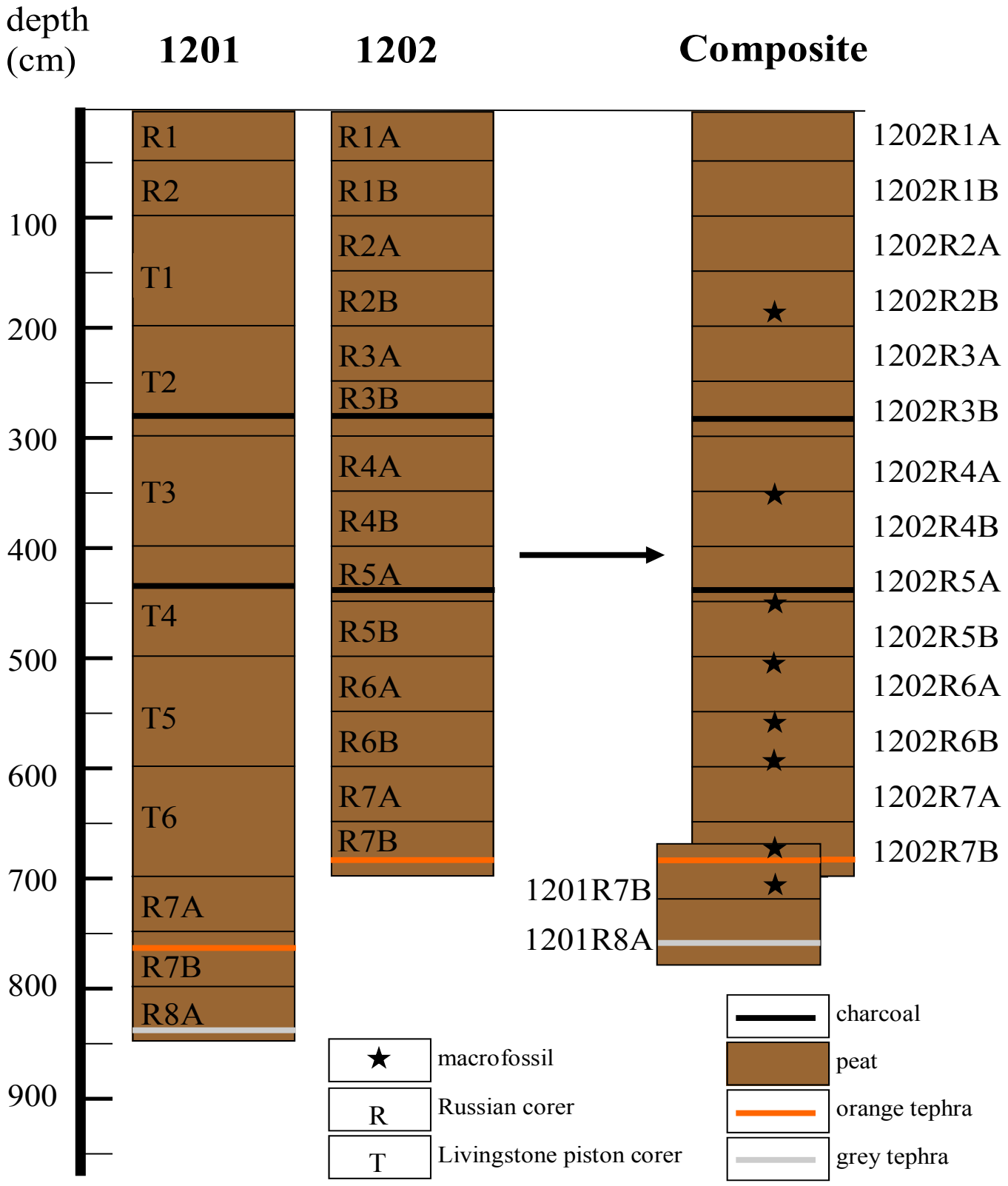

Figure 8: Stratigraphy of core 1201 and 1202 and resulting composite record with depth of macrofossil samples taken for radiocarbon dating (data obtained from Ignacio Jara, VUW) 


\subsection{Chronology}

Radiocarbon dates were obtained from eight plant macrofossil samples extracted from the core at various depths throughout the core by Ignacio Jara (VUW) (Appendix 4.1; Fig. 8). A ninth 'age' of $-62{ }^{14} \mathrm{C}$ (error: 10) at a depth of $0 \mathrm{~cm}$ was added, as the top of the section must be of present age (pers. comm. Ignacio Jara, VUW). The age-depth model was then calculated from $0 \mathrm{~cm}$ to $730 \mathrm{~cm}$ with the open source software Bacon, version 2.2 (Blaauw \& Christen, 2011) using SHCal13 and a postbomb curve for the Southern Hemisphere (SH1-2). As the depth of the oldest sample limits the age-depth model to $730 \mathrm{~cm}$, a linear extrapolation was carried out in order to calculate samples from depth $731 \mathrm{~cm}$ to $750 \mathrm{~cm}$.

\subsection{Subfossil plant cuticle analysis}

A new standardized protocol for retrieval, quantification and identification of plant subfossil cuticles from peat bogs needed to be established. This included the extraction and preparation of peat samples before actual analytical work with the cuticles could be undertaken.

\subsubsection{Sub-sampling regime}

As discussed, sampling was undertaken at two scales of resolution: coarse and fine (Chapter 1.2; Fig. 9). Sampling at coarse resolution was carried out in order to test if subfossil plant cuticles can give a robust reconstruction of local bog surface vegetation changes during the Holocene. In order to do so, samples were extracted across the whole core in broad, evenly spaced intervals. Subsequently, the newly developed method of analysing subfossil plant cuticles was tested further by applying it at a much finer resolution. To this end, peat samples were extracted around three prominent microscopic charcoal peaks in the core analysed by Ignacio Jara (VUW). Subject to the sampling interval adopted and rate of peat accumulation, the analysis of the cuticle record at fine resolution provides a possible means for reconstructing the successional pathway of the vegetation assemblage after a destructive fire event on the bog surface. By choosing to sample around three charcoal layers, it was further hoped to find common response patterns of vegetation assemblages after the fire. 
Coarse

resolution

\section{Fine}

resolution

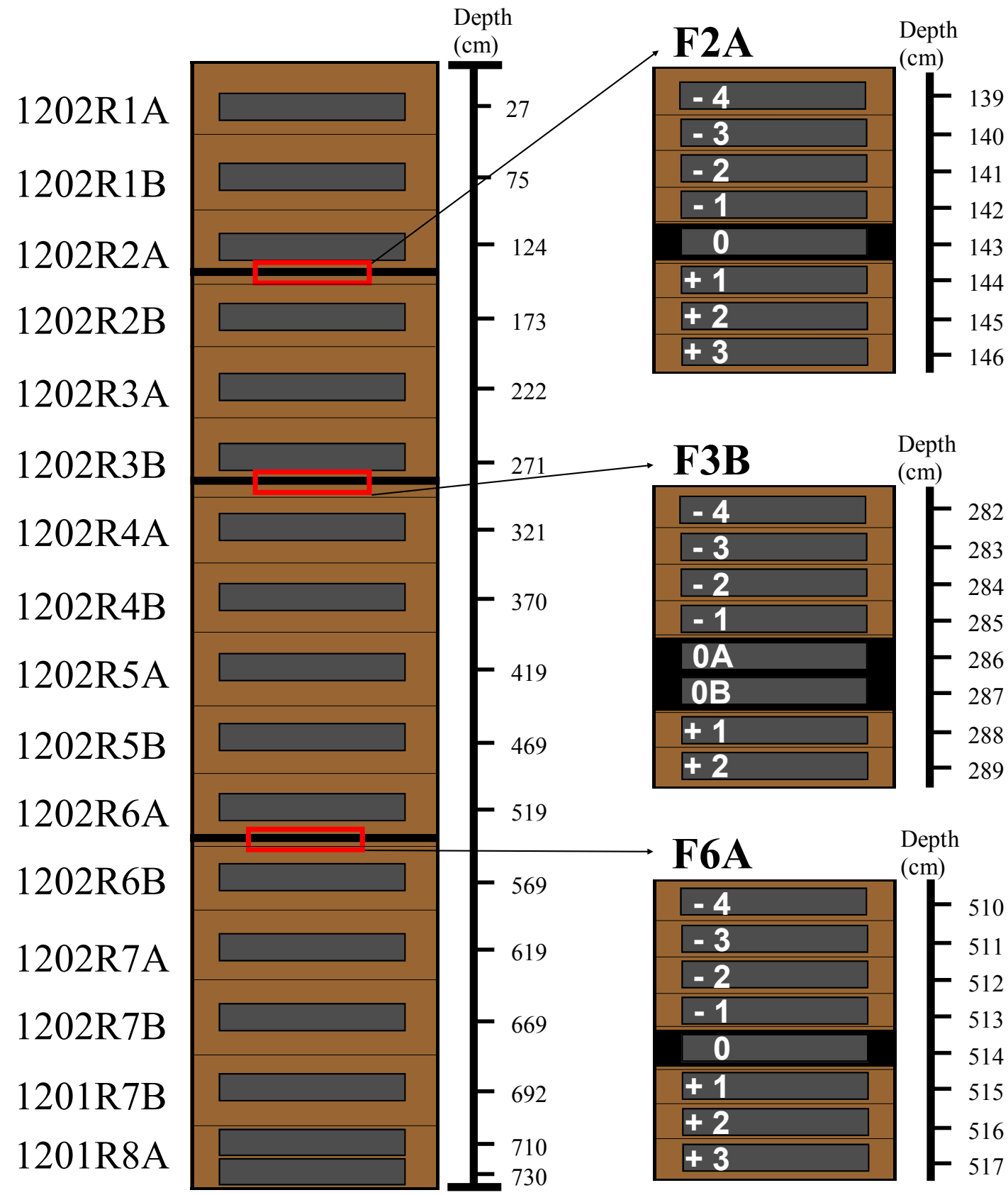

\section{Coarse resolution}

$\rightarrow 2.5 \mathrm{~g}$ from $2 \mathrm{~cm}$ every $\sim 50 \mathrm{~cm}$ Fine resolution

$\rightarrow 2 \mathrm{~g}$ from $1 \mathrm{~cm}$ every $1 \mathrm{~cm}$
Charcoal layer

$\square$ Sampling location 


\subsubsection{Extraction of samples}

The sampling process for both scales of resolution followed the same standardized protocol and included the same steps of extracting and then preparing the samples for further analysis. Nevertheless, due to the large difference in sampling resolution, sample weights varied. Additionally, further material needed to be extracted from the same sampling locations at both scales of resolution for loss-on-ignition and bulk density analyses.

\section{Coarse resolution}

Samples were extracted every $\sim 50 \mathrm{~cm}$ (average of approximately 1000 years based on accumulation rates for whole core, Chapter 4.1) and consequently 17 samples were collected, which are spaced evenly across the whole sequence. In this way a broad understanding of the Holocene vegetational history of Moanatuatua Bog can be obtained at the same time as demonstrating the capacity of subfossil plant cuticles to record the main local vegetation changes.

When deciding on the location of the sample extraction site, a careful examination of each individual drive was first carried out. Samples from the middle section of each drive were extracted rather than from the immediate top or bottom, as to avoid disturbances caused by the coring process. If the sampling location contained visible large wood or root remains, the location was dismissed and sampling moved a few centimetres up or down the drive in order to avoid over- or under-representation of certain material. After deciding on the ideal sampling location, material was collected by extracting it over a $2-\mathrm{cm}$ segment from the core. Sampling on the first drive (1202R1A, $27 \mathrm{~cm})$ was done between 26 and $28 \mathrm{~cm}$. Subsequently, all following samples were taken approximately $50 \mathrm{~cm}$ stratigraphically below. The reason behind the approach of collecting over a $2-\mathrm{cm}$ segment is the rather large amount of sample needed to obtain an accurate reconstruction of the peat-forming plant assemblages. For the analysis at coarse resolution, a sample size of $2.5 \mathrm{~g}$ was chosen (pers. comm. Aline Homes, VUW). Additionally, another $2.5 \mathrm{~g}$ of material were extracted at the same time as a backup and for bulk density as well as loss-onignition analysis. With the opportunity of acquiring material over a 2-cm segment, there was no need to cut a whole slice out of the core. The drives therefore remained intact and more material was available for further analysis. On the other hand, by 
sampling over a $2-\mathrm{cm}$ segment, rather than cutting a $1-\mathrm{cm}$ slice out of the drives, the age interval for each sub-sample also increased. This was however accepted as a reasonable adjustment on the basis of the coarse resolution objective of the analysis in this step.

\section{Fine resolution}

For the next part of the analysis, which addressed objective three, the sequence was further sampled at a finer resolution around three of the most prominent microscopic charcoal layers in the core. In order to find these layers, the microscopic charcoal record obtained for the same sequence by Ignacio Jara (VUW) was used. His record provided a more precise history of regional fire events as it was obtained on a much

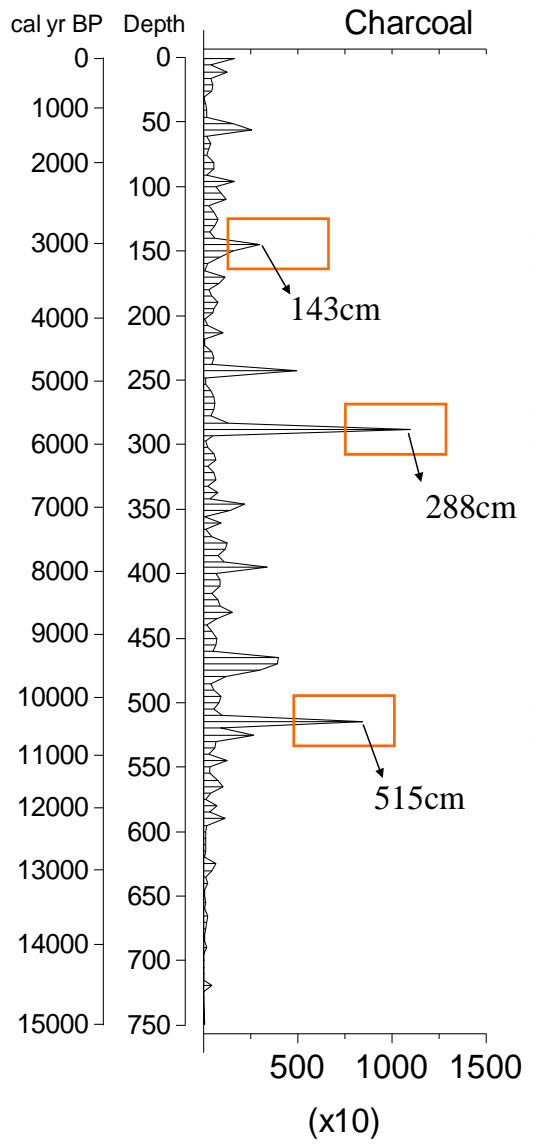

Figure 10: Microscopic charcoal record (data obtained by Ignacio Jara, VUW) with depths of microscopic charcoal peaks finer resolution (same resolution as pollen record, every $5 \mathrm{~cm}$ ) than the macroscopic charcoal record established at coarse

F2A resolution in this work. Due to compaction, oxidisation and storage, it proved difficult to actually see the charcoal layers in the core as subtle colour differences were not obvious. Thus, two layers (F3B and F6A) that showed the highest abundance of microscopic charcoal particles were picked. F6A Additionally, a third layer (F2A) from the top third of the section was sampled. Although it was not the layer with the third highest abundance of microscopic charcoal particles, it displayed a wide charcoal peak, suggesting an extended period of burning may have occurred (Fig. 10). After selecting the microscopic charcoal layers, the relevant drive intervals were studied more

closely. As it was rather difficult to identify the charcoal layers, the surface layer of each drive was scraped off very slightly and fine forceps were used to search for charcoal particles. Charcoal particles were eventually found in abundance about 1-2 $\mathrm{cm}$ stratigraphically above the originally recorded peaks, by hearing the sound of 
brittle charcoal particles crush under the force of the forceps. A small sample of the identified section was then examined under the dissecting microscope in order to validate the existence of charcoal particles. The sampling strategy involved sampling $2 \mathrm{~g}$ of peat every $1 \mathrm{~cm}$ around the charcoal layers. In order to accommodate the increased resolution and still have enough material for further analytical methods, sampling weights needed to be reduced from the coarse sub-sampling strategy. Samples were labelled according to their location in their distinct drive, F2A, F3B and F6A, with a suffix to denote the sample location before, after or during the fire.

Fine resolution analysis F3B (Fig. 11) contains charcoal particles across a 2-cm section, between $38 \mathrm{~cm}$ and $40 \mathrm{~cm}$ of the drive. From the charcoal layer itself, 2 samples were obtained, 4 samples were extracted from $1-4 \mathrm{~cm}$ after the fire event (38 $\mathrm{cm}$ to $34 \mathrm{~cm})$ and 2 samples from $1-2 \mathrm{~cm}$ before the fire event $(40 \mathrm{~cm}$ to $42 \mathrm{~cm}$ ).

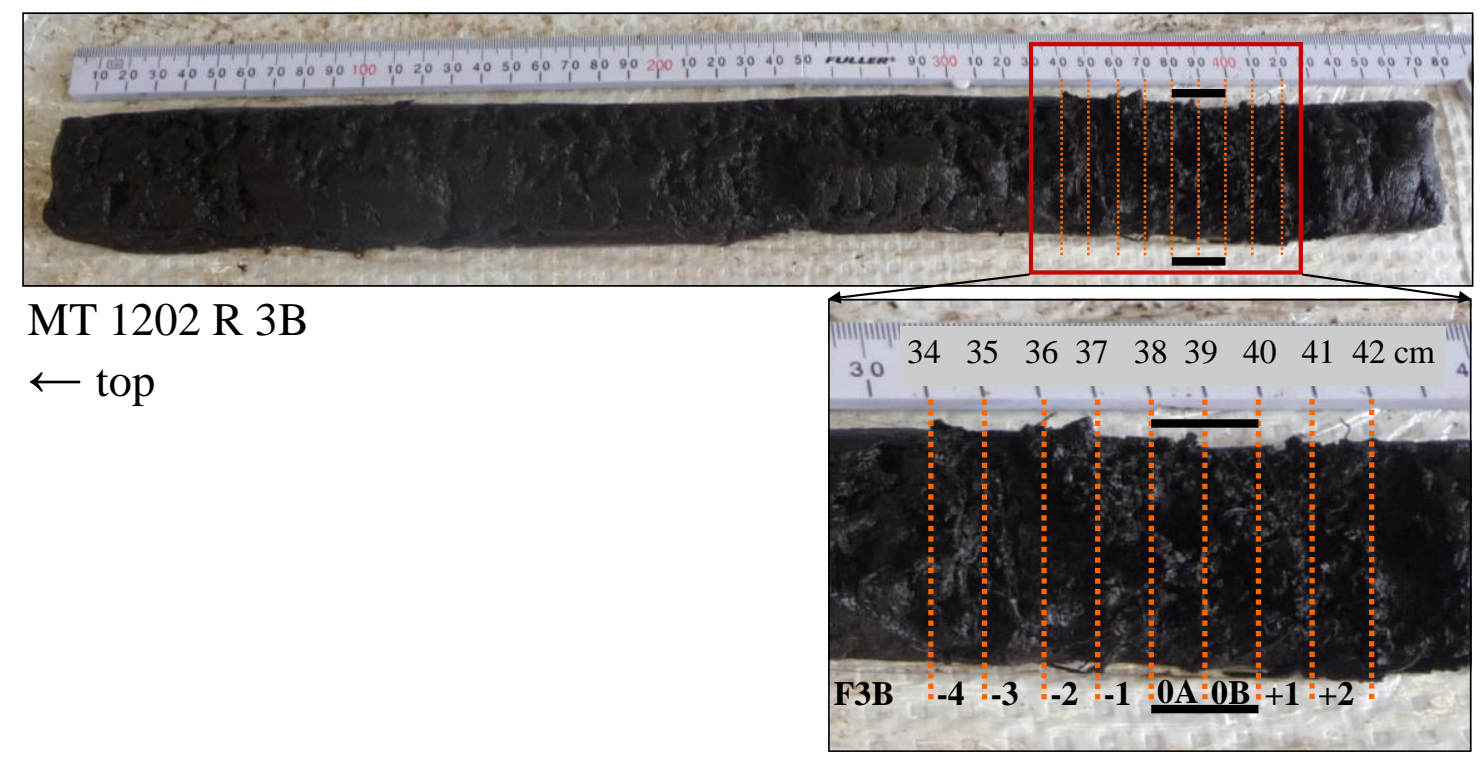

Figure 11: Drive 1202R3B and sampling location for fine-resolution analysis, F3B 
Fine resolution analysis F6A (Fig. 12) contains charcoal particles across a $1-\mathrm{cm}$ section, between $19 \mathrm{~cm}$ and $20 \mathrm{~cm}$ of the drive. Samples were extracted from $1-3$ $\mathrm{cm}$ before the fire $(20 \mathrm{~cm}$ to $23 \mathrm{~cm})$ and $1-4 \mathrm{~cm}$ after the fire $(19 \mathrm{~cm}$ to $15 \mathrm{~cm})$.

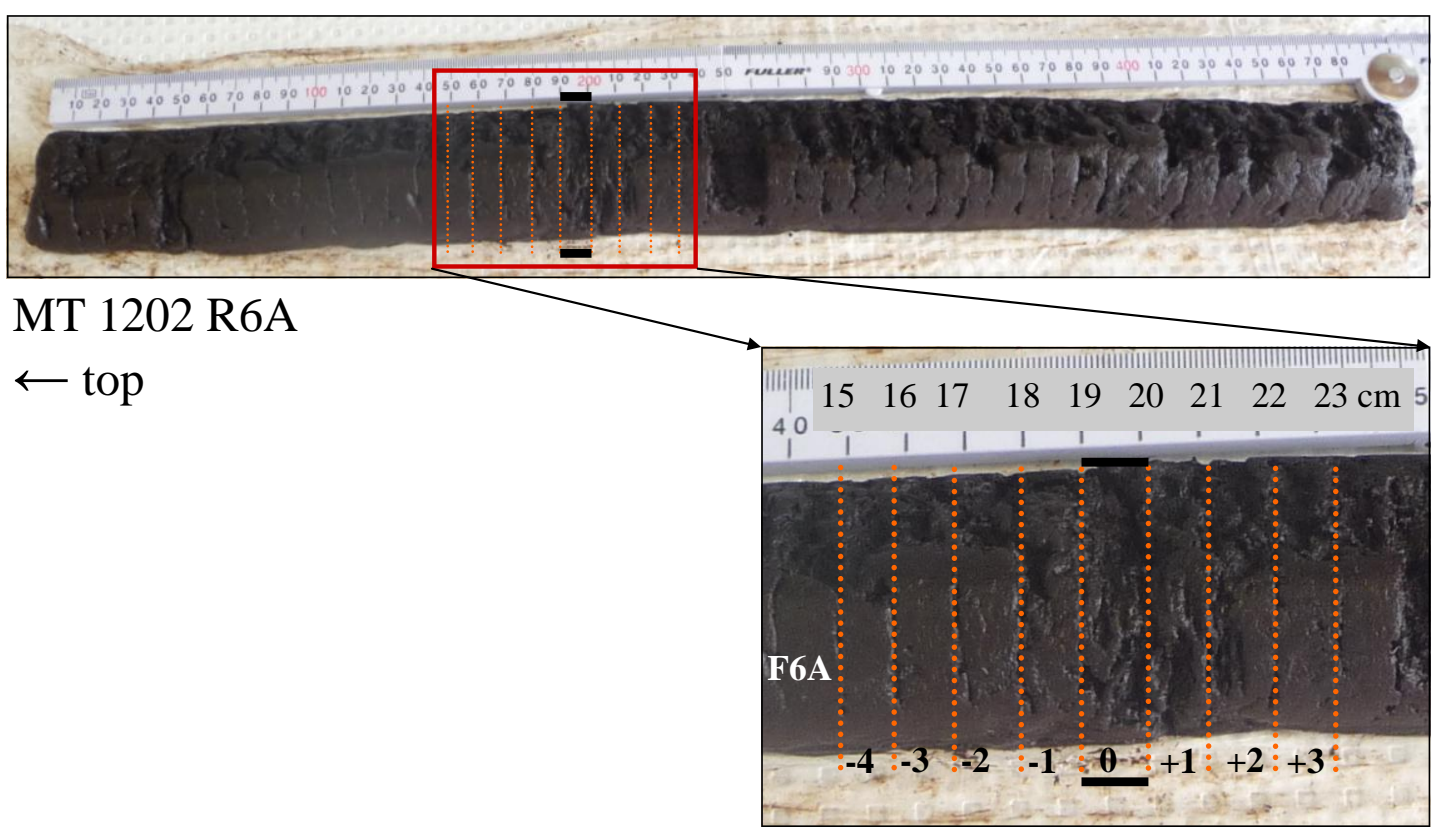

Figure 12: Drive 1202R6A and sampling location for fine-resolution analysis, F6A

Fine resolution analysis F2A (Fig. 13) contains charcoal particles across a 1-cm section, between $44 \mathrm{~cm}$ and $45 \mathrm{~cm}$ of the drive. Samples were extracted from 1 - 3 $\mathrm{cm}$ before the fire $(44 \mathrm{~cm}$ to $48 \mathrm{~cm})$ and $1-4 \mathrm{~cm}(44 \mathrm{~cm}$ to $40 \mathrm{~cm})$ after the fire.

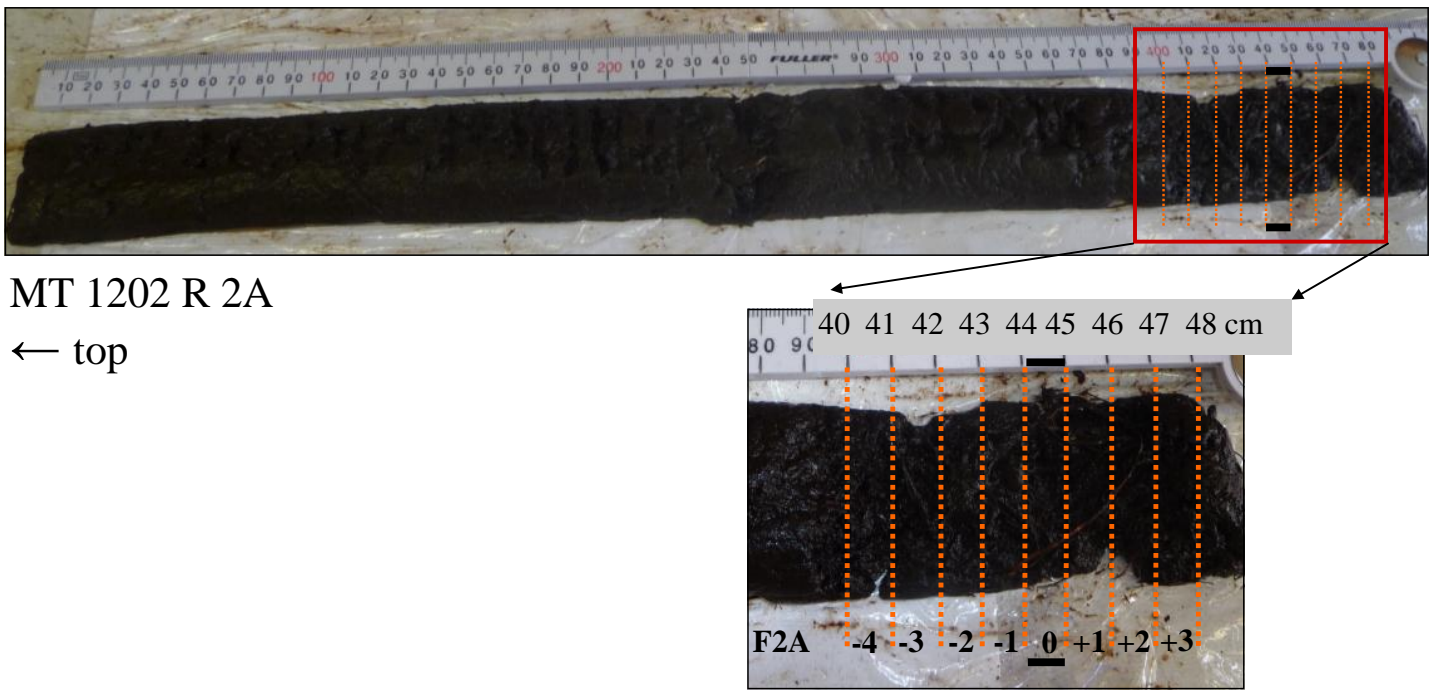

Figure 13: Drive 1202R2A and sampling location for fine-resolution analysis, F2A 


\subsubsection{Preparation}

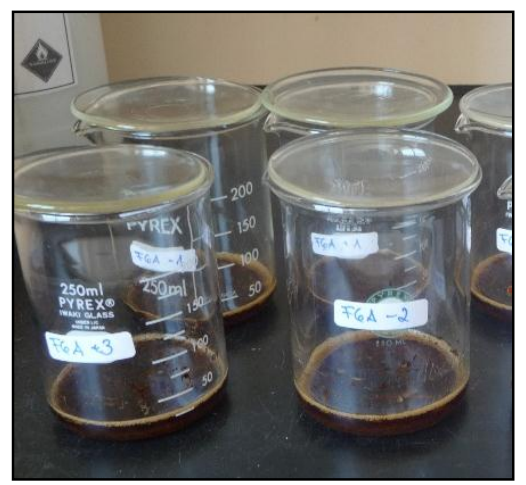

Figure 14: Sample preparation. Disaggregating sample material in fume hood
The preparation process for the peat remains from both scales of resolution followed a combination of standard methods (pers. comm. Aline Homes, VUW) used in plant cuticle analysis, generally for remains originating from pre-Quaternary sediments or rocks (Pole, 2007a; Pole, 2007b; Pole, 2007c; Pole et al., 2008; Pole \& Vajda, 2009; Lee et al., 2012; Mauquoy et al., 2011).

Each sample (2.5 g) was transferred to a glass beaker. A sufficiently large glass beaker needed to be used (e.g. $250 \mathrm{ml}$ glass beaker; Fig. 14) as the preparation process could result in vigorous frothing of the material. $10 \mathrm{ml}$ of distilled water and $10 \mathrm{ml}$ of $27 \%$ hydrogen peroxide $\left(\mathrm{H}_{2} \mathrm{O}_{2}\right)$ were then added to each sub-sample. Additionally, a few crystals ( $\sim 0.5 \mathrm{~g})$ of tetrasodium pyrophosphate $\left(\mathrm{Na}_{4} \mathrm{P}_{2} \mathrm{P}_{7}\right)$ were added to the mixture. The role of distilled water was to bring the peat samples into suspension, whereas hydrogen peroxide and tetrasodium pyrophosphate were both used as sediment dispersers. Both chemicals help in breaking down and disaggregating the sample material. A plastic spatula was then used to gently stir the mixture and to make sure no peat particles adhered to the side of the beaker. Next, beakers were covered with a watch glass and placed in a fume hood for 48 hours to allow the peat to break down and the humates to dissolve (Fig. 14). It is recommended to check the samples during that time, as some samples might be prone to froth quite strongly, depending on the material. The sample was stirred halfway through the preparation process to make sure that no material adhered to the side of the beaker. If the reaction seems to slow down or the peat sample is not breaking down completely, it is necessary to place the beaker in a boiling bath $\left(100^{\circ} \mathrm{C}\right)$ to reinvigorate the reaction. After 48 hours and the complete breakdown of the peat remains, the samples were washed on a $150-\mu$ m nylon mesh using a squeezy bottle and $800 \mathrm{ml}$ of distilled water (Fig. 15). The $>150-\mu \mathrm{m}$ remains were refrigerated in plastic vials or containers with some distilled water in order to prevent further decomposition or contamination by bacteria or fungi. 

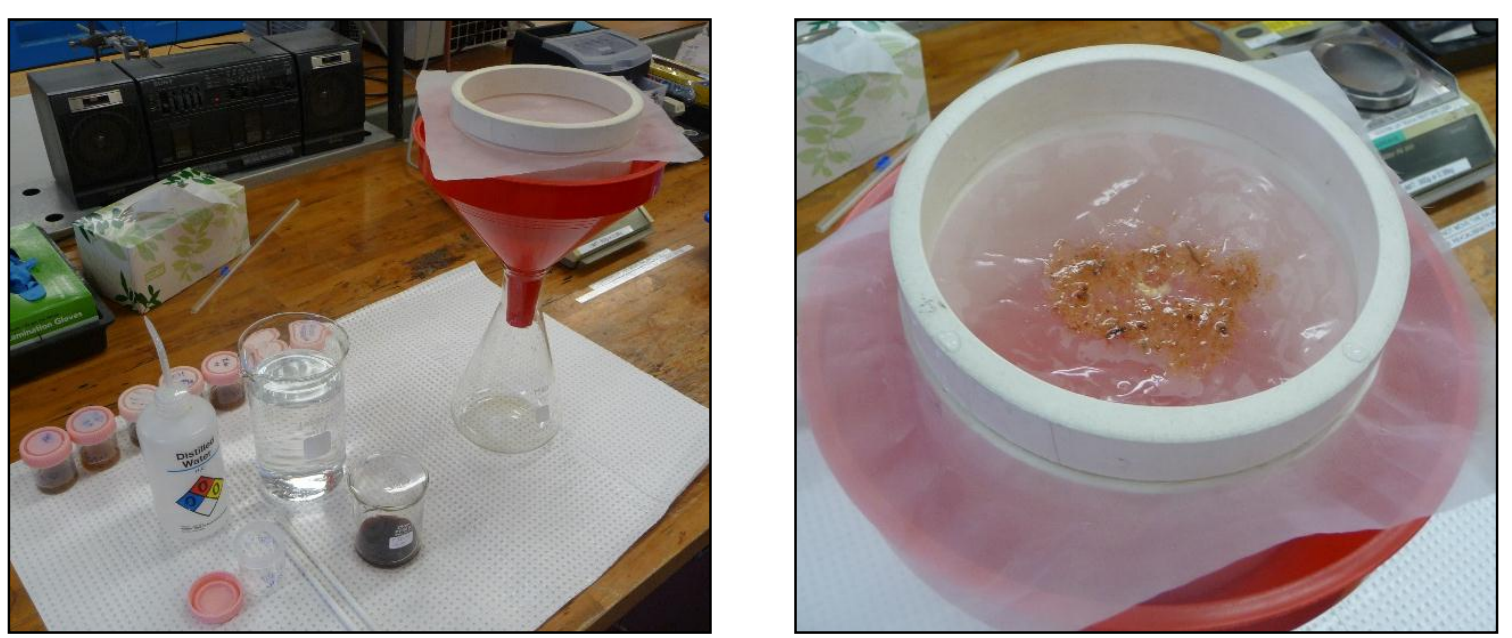

Figure 15: Sample preparation. Washing and sieving of the remaining disaggregated material

\subsubsection{Basic plant macrofossil analysis}

Before further examination of the samples for cuticle analysis, the peat remains were systematically scanned under a low power $(10 \mathrm{x}-40 \mathrm{x})$ dissecting microscope as a preliminary assessment of the plant macrofossil record. This step was necessary for providing a basic outline of the vegetation and fire history of the bog, both at fine and coarse resolution. The remaining sample after sieving was transferred to round petri-dishes and enough distilled water was added to create a single layer of remains. However, depending on the size of the available petri-dishes and the quantity of the sample, the use of multiple petri-dishes may be necessary. By creating a single layer of remains, the overlapping of various plant fragments and remains is avoided, which allows for a more accurate examination of the samples. In an attempt to systematically count all fragments, a ruled piece of paper was placed under the petridishes. All peat components were then counted line by line by moving the paper with the petri-dish.

First, all whole remains and countable fragments such as seeds, spores, fruits, fern sporangia and charcoal were counted. Fragments were counted if more than $50 \%$ of the original item remained in order to provide an accurate counting strategy. For the macroscopic charcoal counting, all visible material was counted and no subdivision into different size classes was undertaken as all material was $>150 \mu \mathrm{m}$. In addition to counting plant remains and fragments, the presence or absence of glass shards (tephra) in all samples was noted. Furthermore a description of the abundance of remains and occurrence of visible restiad cuticles for all samples was established. 


\subsubsection{New method}

In general, plant cuticles are only examined if differentiation between two similar species, such as Baumea and Schoenus, is necessary (e.g. Newnham et al., 1995). Another study from New Zealand examined all retrieved plant cuticle material alongside a standard plant macrofossil analysis. However, results only recorded either 'minor' or 'major presence' of individual species (Walker et al., 2001). In order to obtain a subfossil plant cuticle record, the first objective of this study was to develop a new methodology to retrieve (Chapter 3.3.1), identify and quantify cuticles from a raised peat bog. Furthermore, it was necessary to establish a methodology which follows standardized procedures and analytical steps in order to allow accurate and comparable results in the future.

For that reason, different elements from various plant macrofossil techniques were assessed and subsequently combined to develop the new technique. The semiquantitative quadrat and leaf-count macrofossil analysis (QLC; Chapter 2.1) delivers the basic outline as well as recognized guidelines for the establishment of a new plant cuticle analysis. It is considered to be the main source of information regarding palaeoclimate data from peatlands in the Northern Hemisphere. This is especially true for Sphagnum-dominated mires in northern Europe. However, the QLC method is not well adapted to locations with different peat compositions and vegetation assemblages such as in the Southern Hemisphere (Barber \& Charman, 2005). It is therefore not surprising that this traditional technique is not the method of choice in New Zealand peat studies and a different approach is needed to gain palaoeclimate reconstructions. In particular, raised restiad bogs in the Waikato Region are not suitable for the use of the QLC analysis due to their dominance by species from the Restionaceae family and their generally less varied peat composition. Furthermore, due to the absence of Sphagnum species, the second step of the analysis cannot be undertaken, which reduces the accuracy of the palaeoenvironmental reconstructions. Modifications to the method were therefore necessary to adapt to the location and the unique vegetation assemblage. 


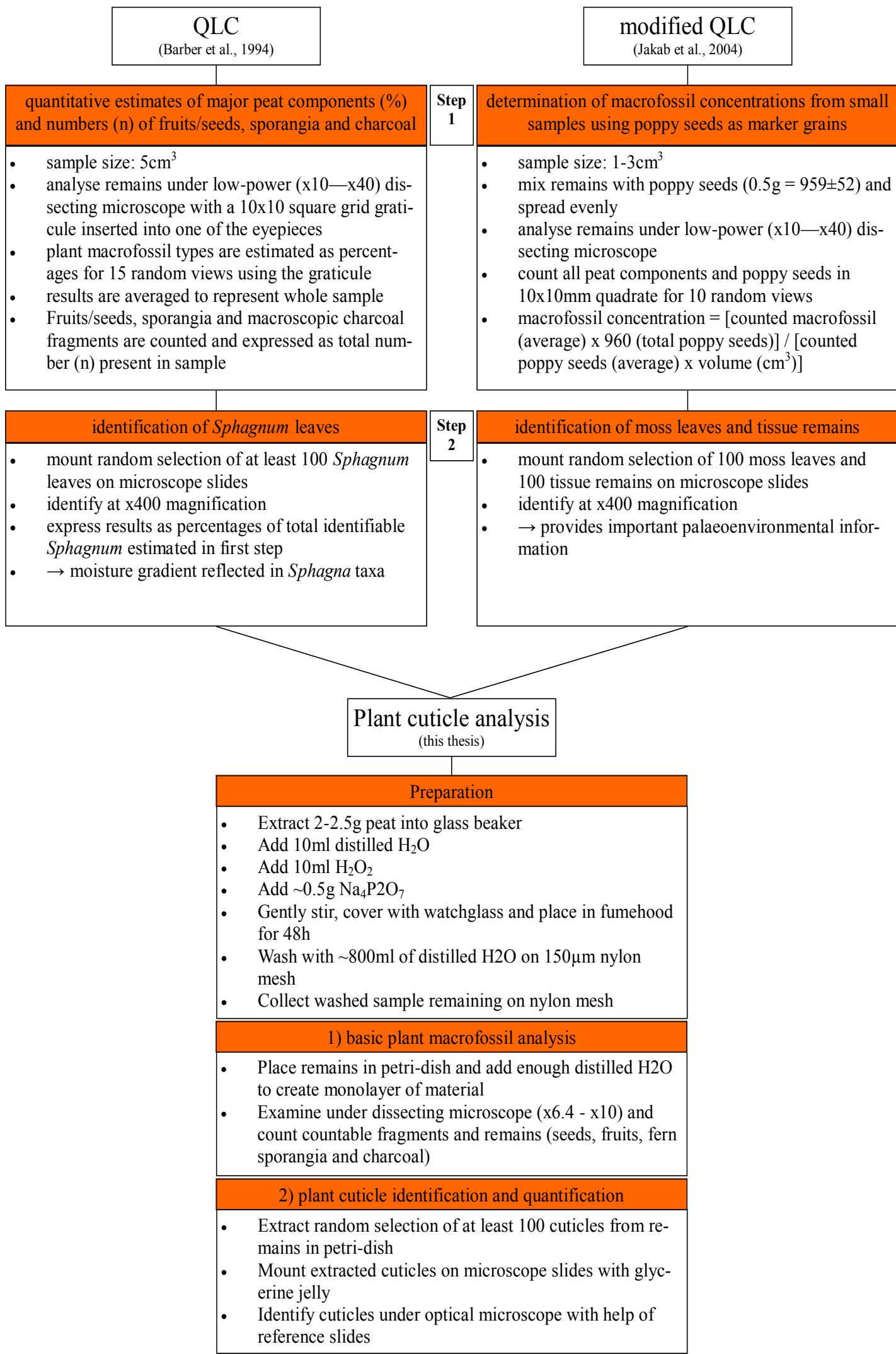

Figure 16: Summary of QLC method (Barber et al., 1994), modified QLC method (Jakab et al., 2004) and plant cuticle analysis (compiled from Barber et al., 1994; Jakab et al., 2004; Mauquoy et al., 2011) 
Jakab et al.'s (2004) study of a eutrophic mire in Central Europe provides more insight towards the establishment of the new plant cuticle method (Fig. 16). The study stated that vegetative plant tissues are not commonly identified in plant macrofossil analyses although they represent the most common group of remains in sediments. A lack of reference material and identification manuals was regarded as being the reason for the lack of interest in them. Furthermore, due to the eutrophic environment, decomposition was higher than in the northern Europe raised bogs and remains such as leaves are harder or impossible to identify. Additionally, as the studied mire is made up of sedge peat, its composition varied significantly from the Sphagnum-dominated bogs, which are the model for the standard QLC approach. It was therefore necessary to modify the traditional method for plant macrofossil analysis and adapt it to the conditions of the field location. Jakab et al. (2004) did this by extracting 100 moss leaves and 100 tissue remains instead of 100 Sphagnum leaves in the second step of analysis (Fig. 16). Additionally, the authors added a spike of poppy seeds as marker grains to the remains in the first step of analysis. This enabled the calculation of the concentration of peat components rather than estimating percentages from a small sample. The extracted moss leaves and tissue remains were mounted on microscope slides and identified under a high-powered microscope, similar to the original QLC method. All remains were divided into specific or non-specific peat components (Table 7) and identified accordingly (Jakab et al., 2004).

Table 7: Specific and non-specific peat components (modified from Jakab et al., 2004)

\begin{tabular}{|l|l|}
\hline Specific peat components & - Seeds, fruits \\
(identification to species level & - Bryophytes \\
possible) & - Rhizodermal and epidermal tissue \\
\hline \multirow{2}{*}{ Non-specific peat } & - Insect remains \\
components & - Monocot. Undiff. - unidentifiable monocotyledons \\
(identification to species level & - UOM - unidentifiable organic matter \\
generally not possible) & - ULF - unidentifiable leaf fragment \\
& - Sphagna undiff. (Sphagnum stem) \\
& - Charcoal \\
\hline
\end{tabular}

For the development of the new plant subfossil cuticle analysis both methods were combined and adapted to the needs of analysing plant cuticles from a raised restiad bog. The first step of the analysis is the plant macrofossil analysis described in 
Chapter 3.3.2. As a second step, in order to test if subfossil plant cuticles can give a robust reconstruction of bog vegetation changes during the Holocene, a random selection of at least 100 cuticles per sample was extracted. Tissue remains that looked rather translucent under the dissecting microscope were the preferred option as it is more likely that only the cuticle layer is extracted. Subfossil plant cuticles were picked from the petri-dishes and temporarily stored in distilled water. The extracted cuticles were mounted on microscope slides and covered with cover slips for further identification. This was done with glycerine jelly on a hotplate as glycerine jelly turns liquid at approximately $\sim 65^{\circ} \mathrm{C}$ (Pott \& Kerp, 2008). A few drops of liquid glycerine jelly were added to the microscope slide on the hotplate and the extracted plant cuticles were embedded into the chemical before being covered with a coverslip. During the cool-down process, the liquid glycerine jelly hardens and the preparations are ready for identification. For permanent storage, the edges of the coverslips were sealed with clear nail polish. The preparations were then examined and identified with an optical microscope. Photographs of the cuticles were made using a microscope (Leica Diaplan) fitted with a digital camera (Leica DFC 280) and the software IrfanView. Results were plotted using the software Tilia (Version 1.7.16; Grimm, 2011).

\subsubsection{Identification}

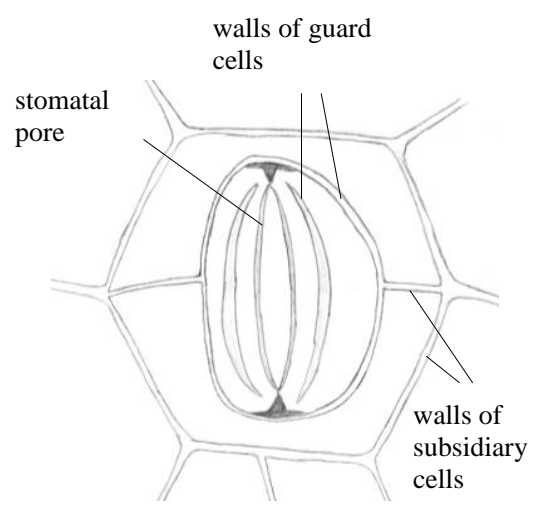

Figure 17: Surface view of stomatal complex (after Dilcher, 1974)

One of the most diagnostic structures on preserved plant cuticles is the stomatal complex (Fig. 17). The complex is made up by the stomatal pore, which is surrounded by two elongated guard cells that, in turn, are bordered by subsidiary (also called neighbouring) cells (Dilcher, 1974; Barclay et al., 2007). Vesque (1889) recognized in the late $19^{\text {th }}$ century, that the distinctive patterns formed by those 
features can be used for taxonomic purposes. He established four main types of stomatal complexes, which he named after the plant family they were characteristic for. Vesque's system was subsequently developed by Metcalf \& Chalk (1950) for dicotyledons and gained widespread acceptance, whilst Florin $(1931 ; 1933)$ proposed a comparable scheme for gymnosperms. Today, these schemes are regarded as too simplistic and as many as 14 types of morphological divisions of stomata have been proposed (Barranova, 1992; Appendix 1.1). Other characters of the plant cuticle can be analysed as well. These include the epidermal cell pattern (Appendix 1.2) and the absence or presence of leaf hairs or oil glands on the surface (Dilcher, 1974; Barclay et al., 2007). Using all epidermal features in conjunction with stomatal complexes allows an accurate and robust method for determining the taxonomy of modern as well as fossil plant cuticles. Identification of subfossil plant cuticles from Moanatuatua Bog involved the study of modern reference material on microscope slides compiled by Aline Homes (VUW). Photographic images (Chapter 4.2) and drawings of relevant cuticles were made. Based on the appearance of the stomatal complex and surrounding epidermal cell pattern (Appendix 1.1 and Appendix 1.2), identification guidelines for the main plant species at Moanatuatua Bog were established (Chapter 4.2).

\subsection{Analytical Methods}

Bulk density and organic matter content by loss-on-ignition (LOI) analysis were measured on all samples at both scales of resolution in order to help understand the long-term history of the bog as well as to develop a better knowledge about the influence of fire events to the ecosystem.

\subsubsection{Purpose of methods}

Dry bulk density is calculated by taking a known volume of wet peat and determining the amount of dry material after drying the sample overnight in a lowtemperature oven. Results are given as the weight of dry sample per $\mathrm{cm}^{3}$ of original wet volume. Bulk density therefore represents a direct relationship to water content in the peat deposit. It is often referred to as the 'degree of compaction' as compaction in a peat deposit occurs primarily due to the high water content but may also vary with the botanical composition of the peat, depth of overlying sediment burden and age. As a result, bulk density tends to increase with depth. Climate inferences can 
also be made from bulk density. For example, if water levels are low, anaerobic conditions are reduced and so decomposition rates increase. As a consequence, bulk density is one of the most commonly used proxies to characterize the state of peat decomposition as it is a relatively rapid and inexpensive process that requires little sample material (Newnham et al., 1995; Chambers et al., 2011; Hansson et al., 2013).

The content of organic matter is measured by burning the dried sub-samples in a high-temperature oven for four to six hours. Results are given as the percentage of organic matter in the sample. By burning the samples at high temperature, organic matter is oxidized to $\mathrm{CO}_{2}$ and ash. This weight-loss can easily be measured and is closely correlated to the amount of organic matter in the deposit. Consequently, LOI analysis is important for determining the relative amount of organic versus minerogenic material in samples. The latter, on a raised peat bog, largely reflects wind-blown dust and volcanic ash, which in turn can be indicative of other climatic and environmental factors, such as drought or fires (Dean, 1974; Heiri et al., 2001; Van der Linden \& Van Geel, 2006; Chambers et al., 2011).

\subsubsection{Method}

The following laboratory protocol for determining bulk density and LOI is based on standard procedures compiled by Chambers et al. (2011) with modifications for restiad peat from Gehrels (2009). Chambers et al. (2011) suggests a sample size of 2 $-10 \mathrm{~cm}^{3}$ for accurate and precise estimates of bulk density and organic matter content. However, Gehrels (2009) performed LOI analysis on restiad peat from the Waikato Region and obtained good results from sample sizes of approximately $1 \mathrm{~g}$. Considering the amount of material already extracted for plant cuticle analysis and the need to use the same core for pollen analysis a sample size of $1.25 \mathrm{~cm}^{3}$ was employed. In order to provide an estimate of accuracy, each batch included a triplicate sample. Extracting peat was done at the same sampling locations as for plant cuticle and macrofossil analysis. However, additional samples (Fig. 18; Appendix 2.2) were taken at coarse resolution (halfway between the 50-cm sampling intervals) to establish a more accurate history of the bog. 


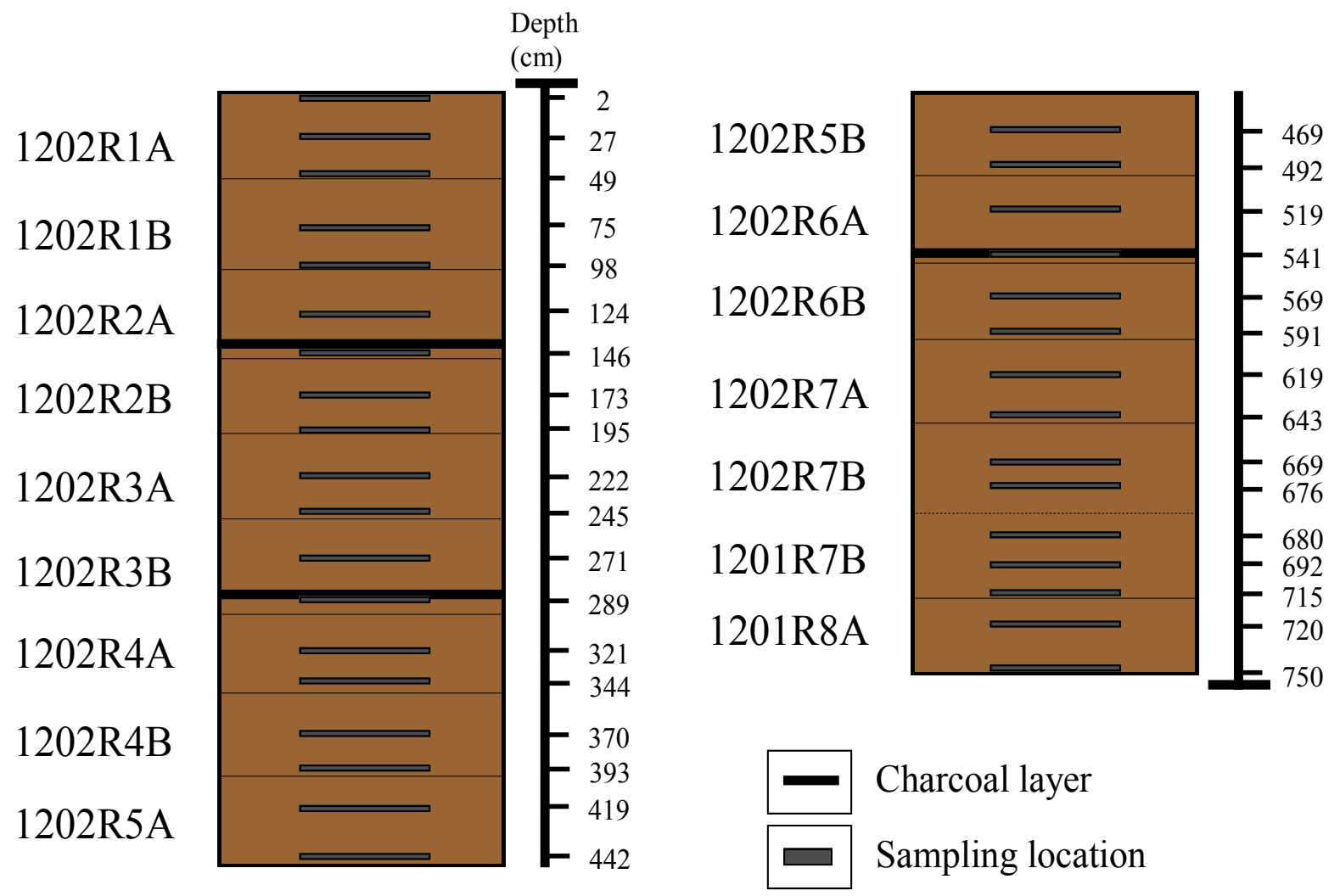

Figure 18: Sampling location for bulk density and loss-on-ignition analysis at coarse resolution

Ceramic crucibles were dried in an oven $\left(105^{\circ} \mathrm{C}\right)$ for approximately $1 \mathrm{~h}$ before being placed in a desiccator to let them cool down. A desiccator was used to prevent the absorption of moisture, which would skew the weight of the crucibles, during the cooling process. Each crucible was then weighed on an analytical scale (accurate to 3 decimal places) to obtain the dry and clean crucible weight (crucible wt; Table 8). A measuring spoon was used to remove $1.25 \mathrm{~cm}^{3}$ of peat (sample vol) and samples were placed in the dried crucibles and weighed again ( $\mathbf{W}_{\text {wet; }}$ minus crucible wt). Crucibles containing the wet samples were dried overnight (approximately $16 \mathrm{~h}$ ) in an oven at $105^{\circ} \mathrm{C}$. After placing the crucibles in a desiccator to let them cool down to room temperature, they were weighed again to obtain the dry weight $\left(\mathbf{W}_{\mathbf{d r y}}\right.$; minus crucible wt). The dried samples were gently crushed with a plastic pestle to ensure a thorough and complete burn, before being placed in a muffle furnace set to $550^{\circ} \mathrm{C}$ for approximately $5.5 \mathrm{~h}$. Crucibles were covered with ceramic lids to avoid contamination and be allowed to cool down in the muffle furnace to ca. $250^{\circ} \mathrm{C}$. Then crucibles were transferred to a desiccator to cool to room temperature and finally weighed again to obtain the weight of the combusted material $\left(\mathbf{W}_{\mathbf{c o m b}}\right.$; minus 
crucible wt). After all weights have been recorded, the samples can be disposed of and calculations (Table 8) were made as follows:

Table 8: Calculations following bulk density and LOI analysis (after Chambers et al., 2011)

\begin{tabular}{|l|c|}
\hline $\begin{array}{l}\text { bulk density } \\
\left(\mathrm{g} / \mathrm{cm}^{3}\right)\end{array}$ & $\frac{\mathrm{W}_{\text {dry }}}{\text { sample vol }}$ \\
\hline $\begin{array}{l}\text { organic matter content } \\
(\%)\end{array}$ & $\frac{\mathrm{W}_{\text {dry }}-\mathrm{W}_{\text {comb }}}{\mathrm{W}_{\text {dry }}} * 100$ \\
\hline
\end{tabular}

\subsection{Summary}

The following figure (Fig. 19) gives an overview and summary of the analytical work involved in this thesis.

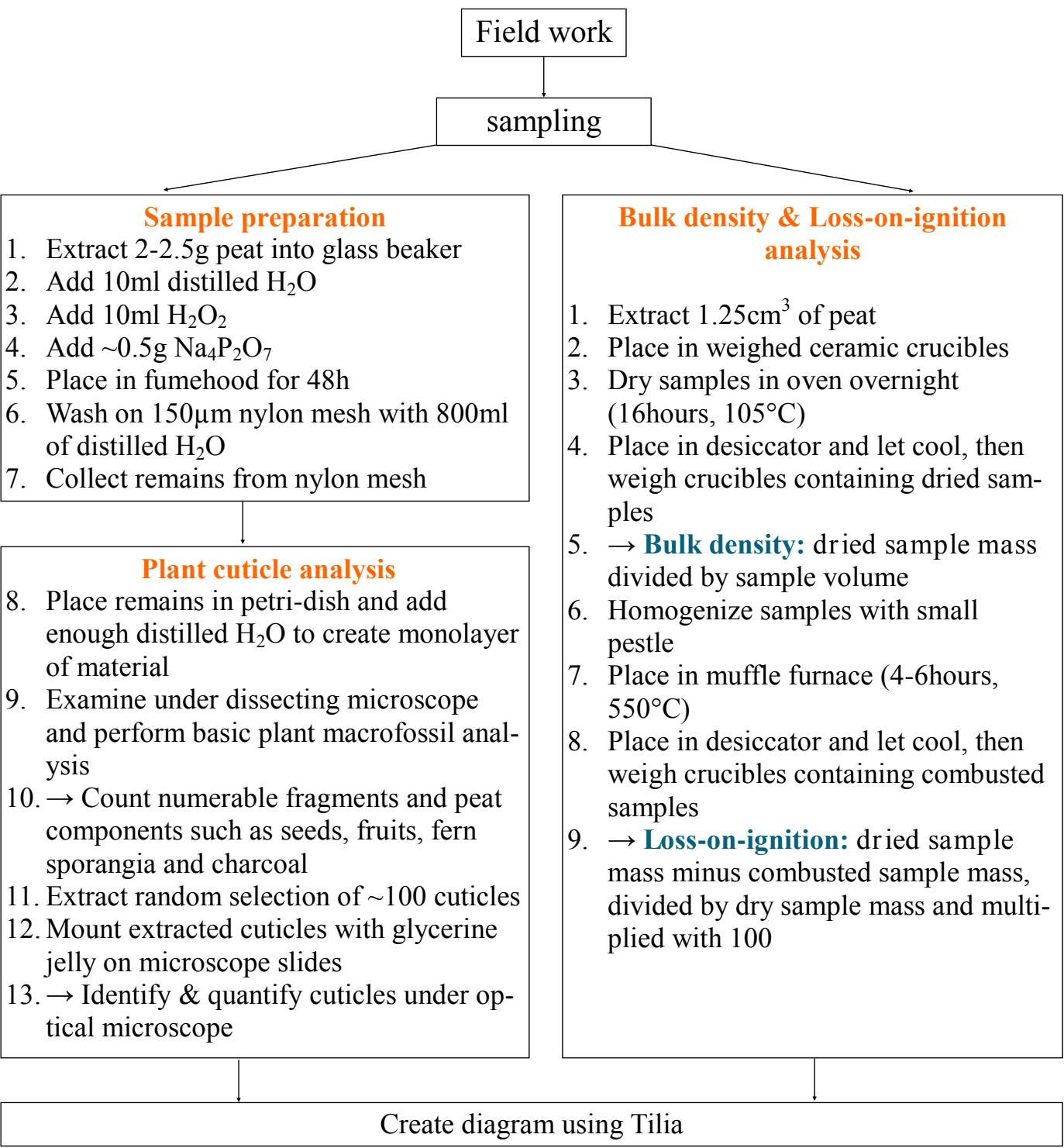

Figure 19: Summary of analytical work 


\section{RESULTS}

The following chapter starts with a presentation of the age-depth model and the resulting accumulation rates for Moanatuatua Bog. A description, including photographs, of the main plant species found in the core is provided, followed by the results of all analyses at coarse and fine resolution.

\subsection{Chronology}

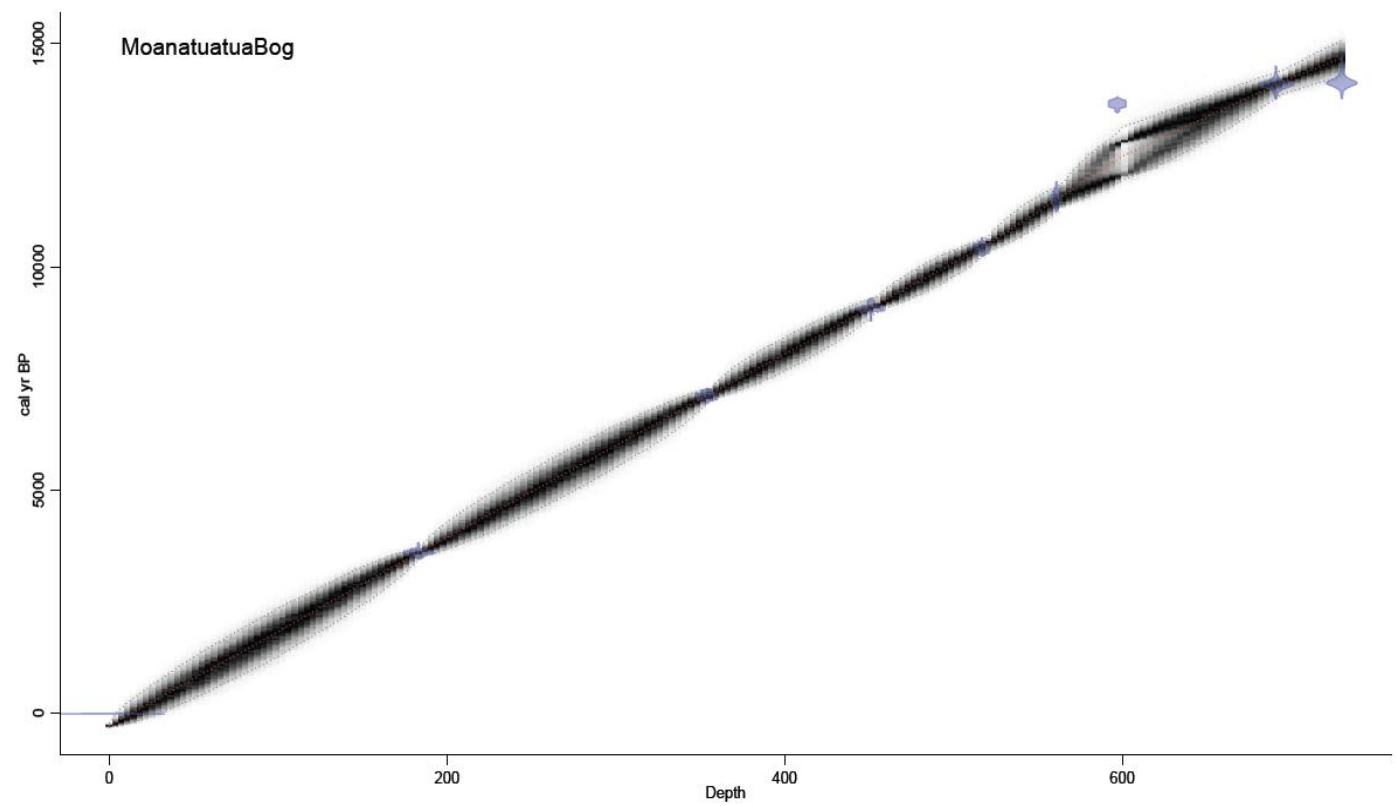

Figure 20: Posterior age-depth models (in grey) derived using Bacon age-depth modelling of Moanatuatua Bog. Calibrated distributions of known dates are shown in blue, grey dots indicate the $95 \%$ probability intervals, red curve shows 'best' model based on the weighted mean age for each depth.

Table 9: Peat accumulation rates estimated between the ${ }^{14} \mathrm{C}$-dated sections of the sequence

\begin{tabular}{|l|c|}
\hline $\begin{array}{l}\text { DEPTH } \\
(\mathbf{c m})\end{array}$ & $\begin{array}{l}\text { ACCUMULATION } \\
\text { RATE }(\mathbf{c m} / \mathbf{y r})\end{array}$ \\
\hline $0-183$ & 0.049 \\
\hline $183-354$ & 0.048 \\
\hline $354-451$ & 0.049 \\
\hline $517-561$ & 0.041 \\
\hline $561-597$ & 0.040 \\
\hline $597-691$ & 0.056 \\
\hline $691-730$ & 0.064 \\
\hline
\end{tabular}

Figure 20 shows the age-depth model of Moanatuatua Bog derived using the Bacon software. To calculate peat accumulation rates between the known ages, the weighted means of the calibrated ages and their associated depths have been used (Table 9): 
Based on these, the average accumulation rate for the whole core, to a depth of 730 $\mathrm{cm}$, is $0.050 \mathrm{~cm} / \mathrm{yr}$. The sampling interval at coarse resolution results in a sample every 1000 years. Due to the adopted sampling procedure, sampling over a $2-\mathrm{cm}$ long segment produces an amalgamation of 40 years of peat accumulation. At fine resolution, sampling at $1 \mathrm{~cm}$ intervals across a $1-\mathrm{cm}$ segment produces samples which represent an amalgamation of 10 years peat accumulation.

\subsection{Plant cuticles}

The following figures (Fig. 21 to Fig. 25) show photographic images and descriptions of cuticles of the main plant species at Moanatuatua Bog. The terminology and identification schemes presented in Appendix 1.1 and 1.2 are only regarded as a basic guideline as these are based on just one major group of angiosperm plant material from the Northern Hemisphere. Furthermore, the guidelines were considered to be too detailed in light of the small number of main plant species present at Moanatuatua Bog. Here, identifications were made by comparing samples with reference material, focussing on the appearance of the stomatal complex, the epidermal cell pattern and absence or presence of oil glands or other distinct individual features.
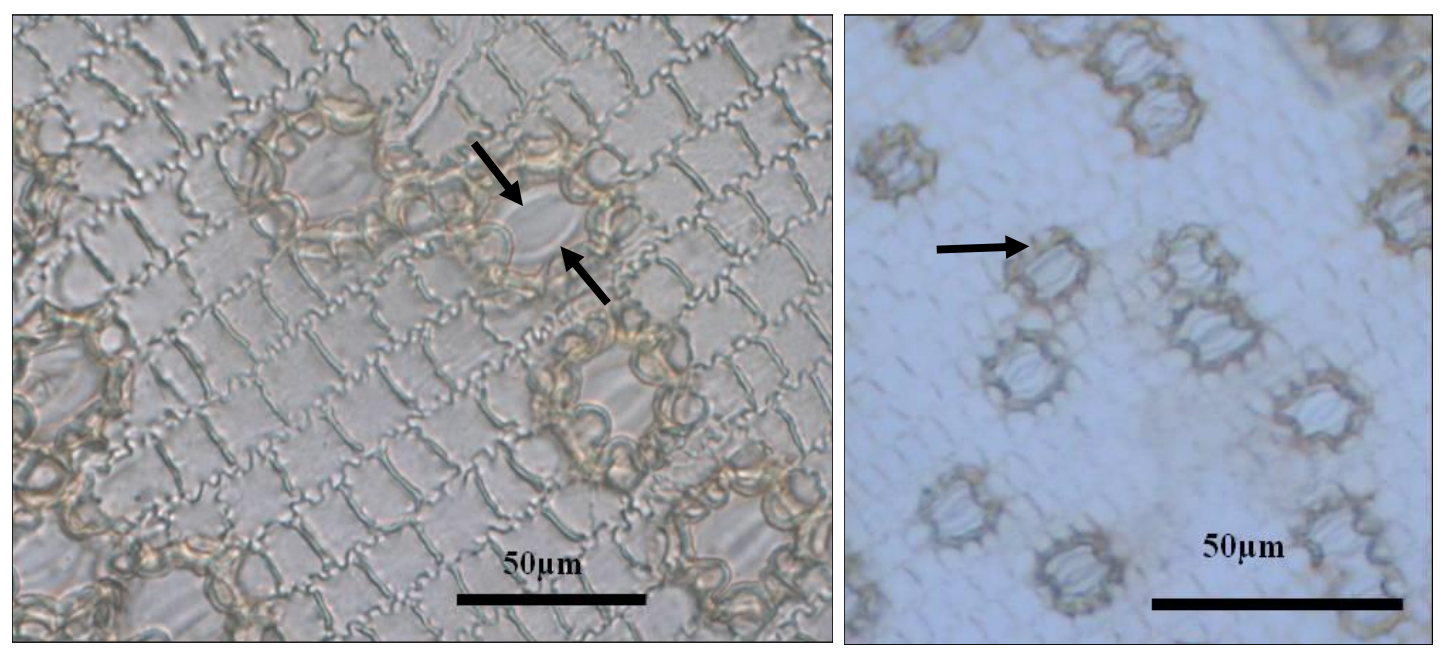

Figure 21: Sporadanthus ferrugineus.

Sporadanthus ferrugineus (Fig. 21): Stomatal complexes are not on the surface but are 'sunken'. The stomatal complexes are randomly distributed but appear to be orientated in the same direction. In comparison with Empodisma, guard cells are more elongate; similar to paracytic stomatal complex type (Appendix 1.1). 
Subsidiary cells with pappilate ornamentation ('darker ring' around guard cells), indicated by the arrow on the right picture, arch over the stomatal complex and partially cover it. The arrows on the left picture show a plain ledge around the stomatal pore. Epidermal cells are rectangular, very regular and display a tetragonal cell arrangement. The side walls are particularly very strongly undulated, with the end walls being straighter.
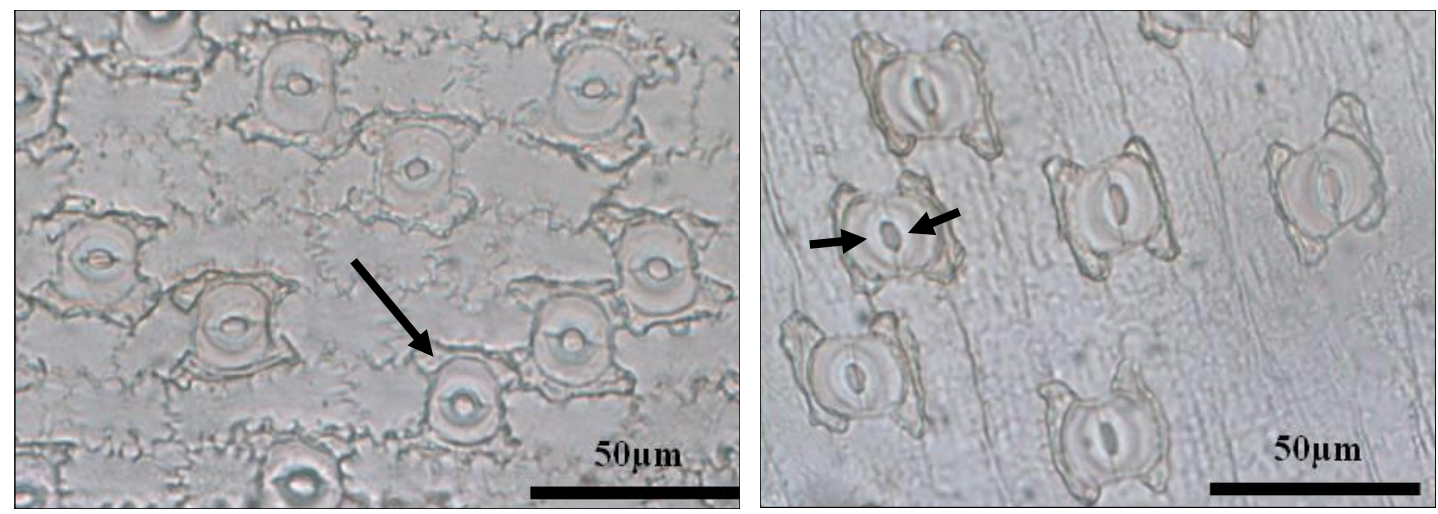

Figure 22: Empodisma robustum.

Empodisma robustum (Fig. 22): Stomatal complexes on the surface are randomly distributed but appear to be orientated in the same direction. The stomatal pore is surrounded by large, semi-circular guard cells; similar to paracytic type (Appendix 1.1). In comparison with Sporadanthus, guard cells are larger and more circular. The arrows on the right picture indicate a prominent plain ledge around the stomatal pore. Subsidiary cells (arrow in left picture) are long and narrow and do not cover up the stomatal complex. The epidermal cells are rectangular and display a strong undulation
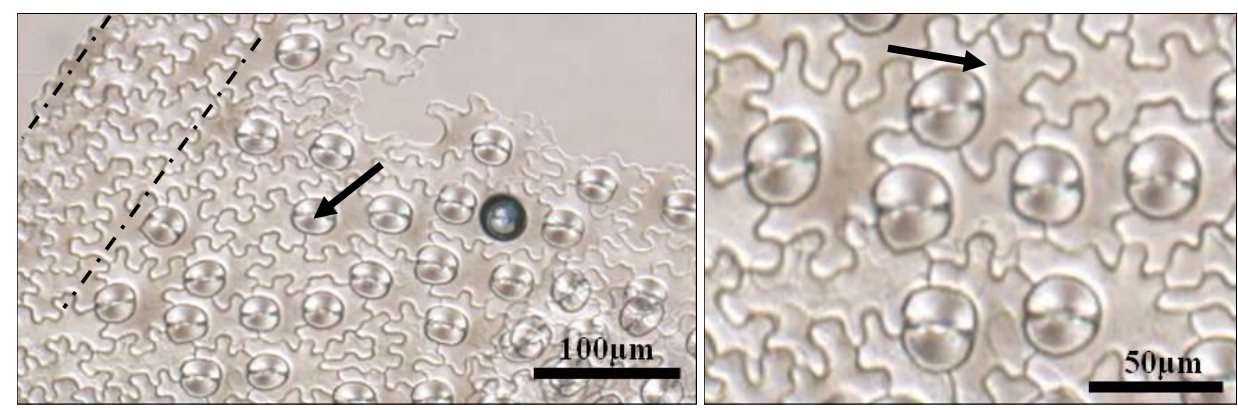

Figure 23: Gleichenia dicarpa. 
Gleichenia dicarpa (Fig. 23): The arrow on the left picture indicates a stomatal complex present on the surface. Stomatal complexes are large and appear to be not strongly orientated. They are randomly distributed, however no stomatal complex is present on the vein on the left side of the left picture (indicated by dashed lines). Guard cells are large half-circles, forming a rectangular shape with rounded edges around the stomatal pore. The stomatal complex is surrounded by large subsidiary cells (indicated by arrow on right picture), which almost wrap around the whole complex; similar to polocytic type (Appendix 1.1). Epidermal cells are very large and form a very distinctive cell pattern. The cell walls are very undulated, u-shaped and resemble a 'jigsaw-puzzle.
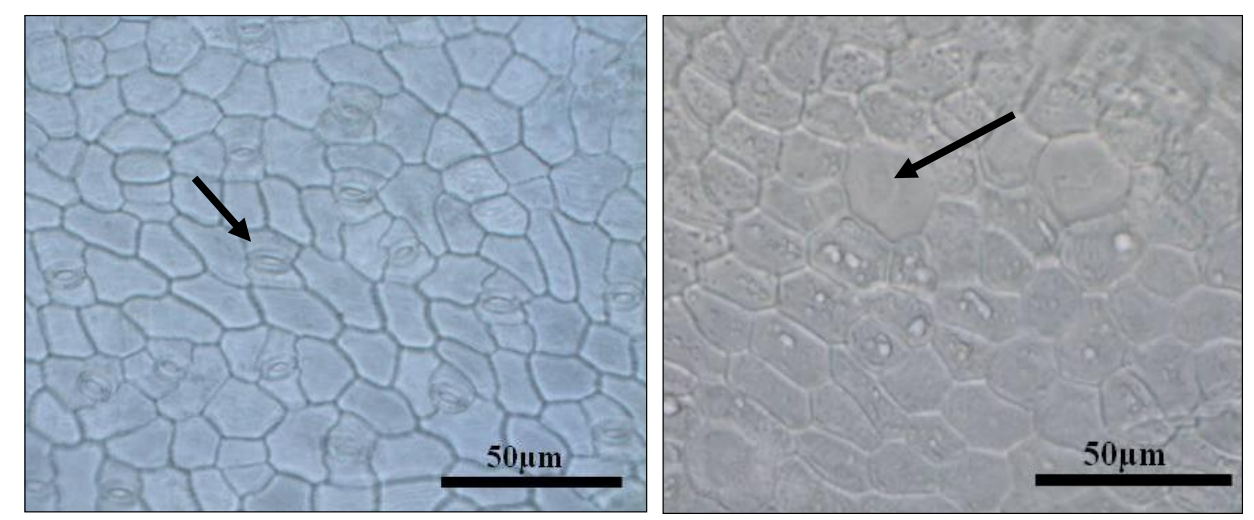

Figure 24: Leptospermum scoparium.

Leptospermum scoparium (Fig. 24): The arrow on the left picture indicates a stomatal complex present on the surface. Stomatal complexes are of medium size and randomly orientated as well as randomly distributed. Guard cells are small and elongated. The epidermal cells are slightly angular, irregular shaped and in an isodiametric pattern. The cell walls are straight to slightly curved. The arrow on the right picture indicates an oil gland surrounded by a ring of cells. The presence of oil glands is a clear indication for Leptospermum. 


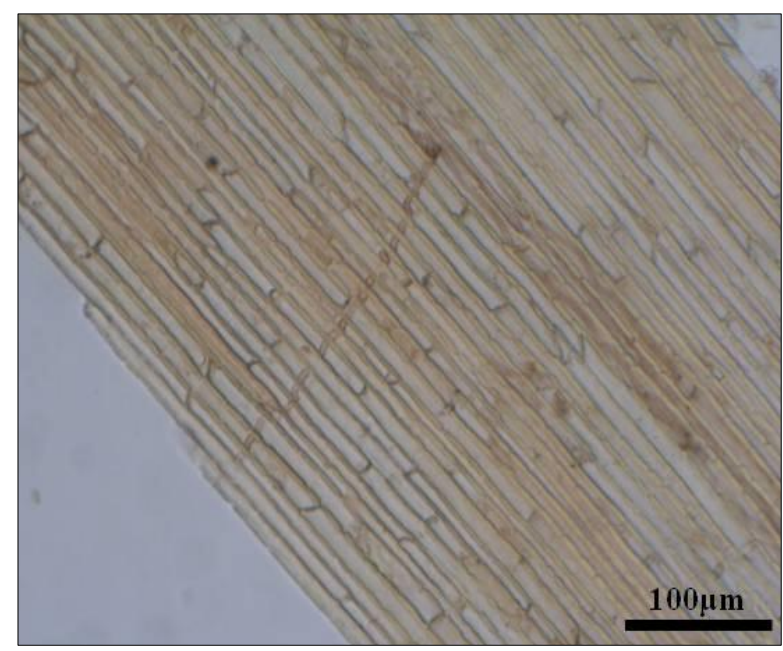

Figure 25: Sedge.

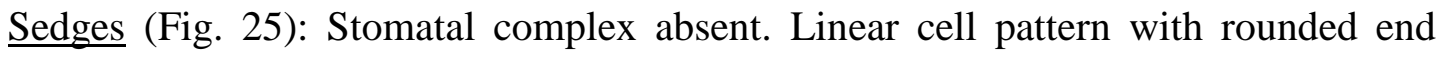
walls.

\subsection{Results at coarse resolution}

As part of the basic plant macrofossil analysis, each sample was described and the presence or absence of volcanic glass shards as well as restiad cuticles was observed. It was possible to identify the presence/absence of restiad cuticles under the dissecting microscope, due to their distinctive, large stomata complex. However, further identification to species level (e.g. Empodisma or Sporadanthus) was not possible at this level and had to be established during the plant cuticle analysis under the optical microscope. Additionally, the state of plant remain decomposition and the overall abundance of plant remains was documented for each sample (Table 10).

Table 10: Description of sample remains at coarse resolution $(0=$ no/ not present; $+=$ very few remains and fragmented; + = some/ small and fragmented; $++=$ many; green $=$ good plant preservation; yellow $=$ medium plant preservation; red $=$ poor plant preservation; grey $=$ no plant remains $)$

\begin{tabular}{|c|c|c|c|c|c|}
\hline $\begin{array}{c}\text { Age } \\
(\mathbf{c a l} \mathbf{~ y r} \\
\text { BP })\end{array}$ & $\begin{array}{c}\text { Depth } \\
(\mathbf{c m})\end{array}$ & Sample & $\begin{array}{c}\text { Glass } \\
\text { shards }\end{array}$ & $\begin{array}{c}\text { Restiad } \\
\text { cuticles }\end{array}$ & $\begin{array}{c}\text { Amount } \\
\text { of } \\
\text { remains }\end{array}$ \\
\hline 294 & 27 & 1202R 1A & + & + & + \\
\hline 1306 & 75 & 1202R 1B & ++ & + & + \\
\hline 2344 & 124 & 1202R 2A & ++ & + & ++ \\
\hline 3385 & 173 & 1202R 2B & 0 & ++ & ++ \\
\hline 4390 & 222 & 1202R 3A & 0 & + & ++ \\
\hline 5396 & 271 & 1202R 3B & 0 & + & ++ \\
\hline 6429 & 321 & 1202R 4A & 0 & ++ & ++ \\
\hline
\end{tabular}




\begin{tabular}{|c|c|c|c|c|c|}
\hline 7441 & 370 & 1202R 4B & + & $(+)$ & $(+)$ \\
\hline 8432 & 419 & 1202R 5A & 0 & $(+)$ & $(+)$ \\
\hline 9455 & 469 & 1202R 5B & 0 & ++ & $(+)$ \\
\hline 10477 & 519 & 1202R 6A & 0 & 0 & ++ \\
\hline 11698 & 569 & 1202R 6B & 0 & 0 & ++ \\
\hline 12811 & 619 & 1202R 7A & 0 & 0 & ++ \\
\hline 13690 & 669 & 1202R 7B & + & 0 & ++ \\
\hline 14086 & 692 & 1201R 7B & ++ & 0 & + \\
\hline 14371 & 710 & 1201R 8A & ++ & 0 & 0 \\
\hline 14676 & 730 & 1201R 8A & ++ & 0 & 0 \\
\hline
\end{tabular}

Overall, plant remains were generally abundant throughout the core, which allowed the extraction of sufficient material for further identification in the subsequent plant cuticle analysis. However, samples 1202R4B (370 cm), 1202R5A (419 cm) and 1202R5B $(469 \mathrm{~cm})$ contained significantly fewer plant remains, which were also very small, fragmented and less well preserved. The extraction of sufficient plant cuticles took longer for these samples. Additionally, the last two samples of the core, 1201R8A at $710 \mathrm{~cm}$ and 1201R8A at $730 \mathrm{~cm}$ contained no plant cuticles. Overall, plant remains were documented until sample 1201R7B at $692 \mathrm{~cm}$, but restiad cuticles were only obvious stratigraphically above sample 1202R5B at $469 \mathrm{~cm}$. Glass shards, were only present in the very top and bottom third of the core and were absent through the whole middle section, except for a small amount in sample 1202R4B at $370 \mathrm{~cm}$.

\subsubsection{Plant cuticle and macrofossil analysis}

Figure 26 displays the results of the coarse resolution plant macrofossil and cuticle analyses, along with the results of the bulk density and LOI analyses. 


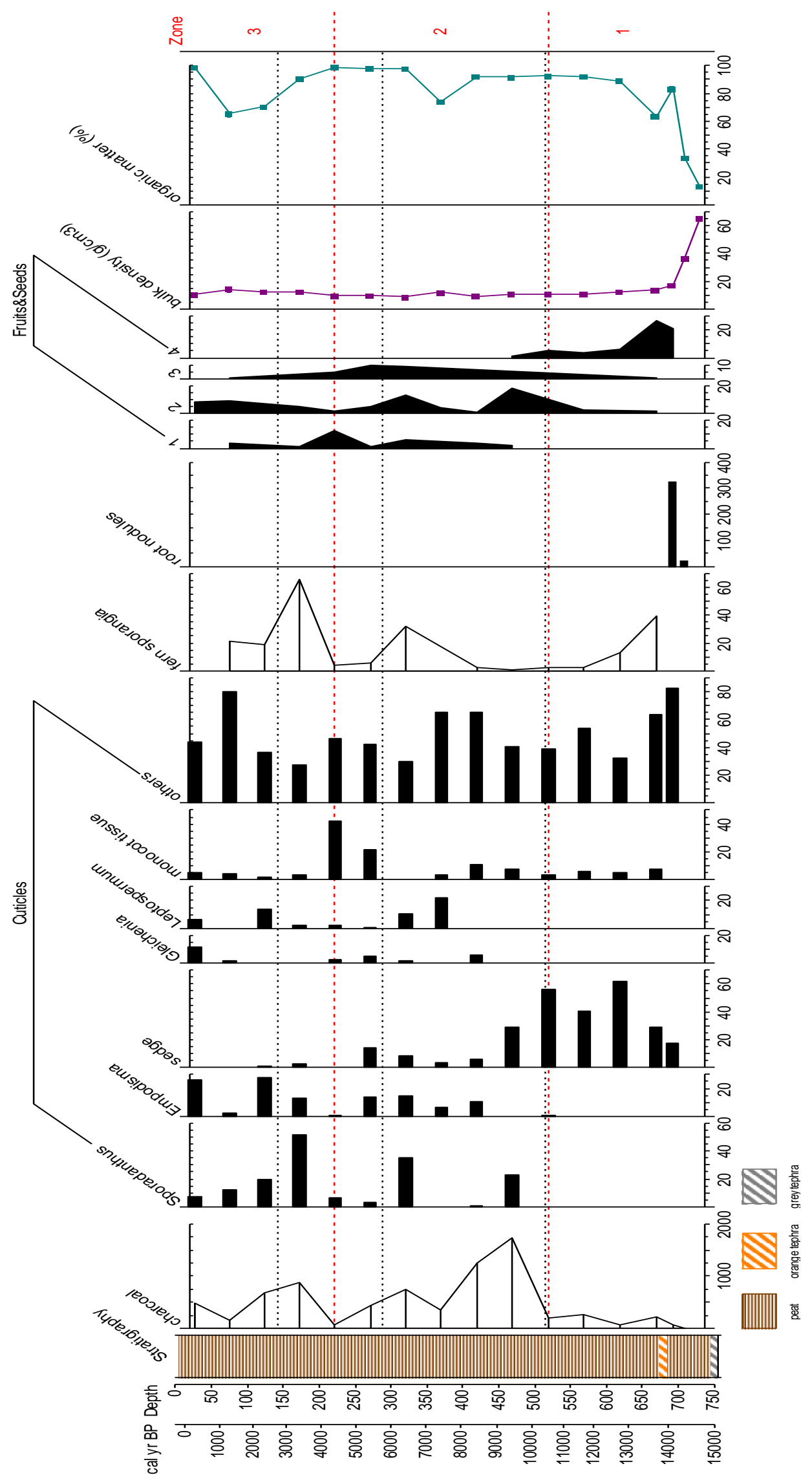

Figure 26: Results of plant cuticle (presented as \% of the total cuticle count), basic plant macrofossil (presented as number of specimens counted) and bulk density (exaggerated by 100x) as well as LOI analysis at coarse resolution. Red dashed lines indicate different zones; black dashed lines indicate location of sampling at fine resolution 
The sequence was divided into three zones, each mainly represented by a change in vegetation composition and charcoal particle abundance (Table 11). The transition from Zone $1(\mathrm{Z} 1)$ to Zone 2 (Z2) was based on the switch from a sedge-dominated vegetation assemblage to a more diversified composition and the significantly increasing amount of macroscopic charcoal particles. The transition from Z2 to Zone 3 (Z3) was characterised by the establishment of a restiad-dominated vegetation assemblage and a drop in the number of macroscopic charcoal particles.

$\mathrm{Z} 1$ is characterised by the absence of any restiad, Gleichenia or Leptospermum cuticles and a relatively low number of macroscopic charcoal particles. Sedges are the dominant component of the vegetation assemblage in this zone. No plant remains, such as plant cuticles, tissue fragments or fruits and seeds are found in the bottom two samples below $700 \mathrm{~cm}$ depth. However, a large amount of root nodules exclusively occurs in these two bottom samples, which also coincide with a drop in the amount of organic matter and a rise in bulk density values. Z2 is characterised by the decrease in sedge cuticles and the appearance of both restiad species, beginning with Empodisma, in the vegetation composition. Subsequently, Gleichenia and Leptospermum cuticles are also found, indicating a more diverse vegetation assemblage. At the same time as the amount of sedges declines, the amount of macroscopic charcoal particles significantly increases. Z3 is dominated by an abundance in both Sporadanthus and Empodisma cuticles, whereas sedge cuticles become absent towards the top of the sequence. Gleichenia and Leptospermum cuticles are also present in this zone, although in lower numbers than in Z2. Fern sporangia, which are assumed to originate from Gleichenia, however also have their highest count recorded in $\mathrm{Z} 3$.

Table 11: Depth, age and defining characteristics of vegetation zones

\begin{tabular}{|l|l|l|l|}
\hline & $\begin{array}{l}\text { DEPTH } \\
(\mathbf{c m})\end{array}$ & $\begin{array}{l}\text { AGE } \\
(\mathbf{c a l} \text { yr BP })\end{array}$ & CHARACTERISTICS \\
\hline Zone 3 & $0-222$ & $0-4390$ & $\begin{array}{l}\text { Restiad-dominated; } \\
\text { moderate amount of charcoal }\end{array}$ \\
\hline Zone 2 & $223-519$ & $4411-10477$ & $\begin{array}{l}\text { Transition between sedges and restiads in } \\
\text { this zone; high amount of charcoal }\end{array}$ \\
\hline Zone 1 & $520-750$ & $10498-14985$ & $\begin{array}{l}\text { Sedge-dominated; } \\
\text { low amount of charcoal }\end{array}$ \\
\hline
\end{tabular}




\subsubsection{Bulk density and LOI analyses}

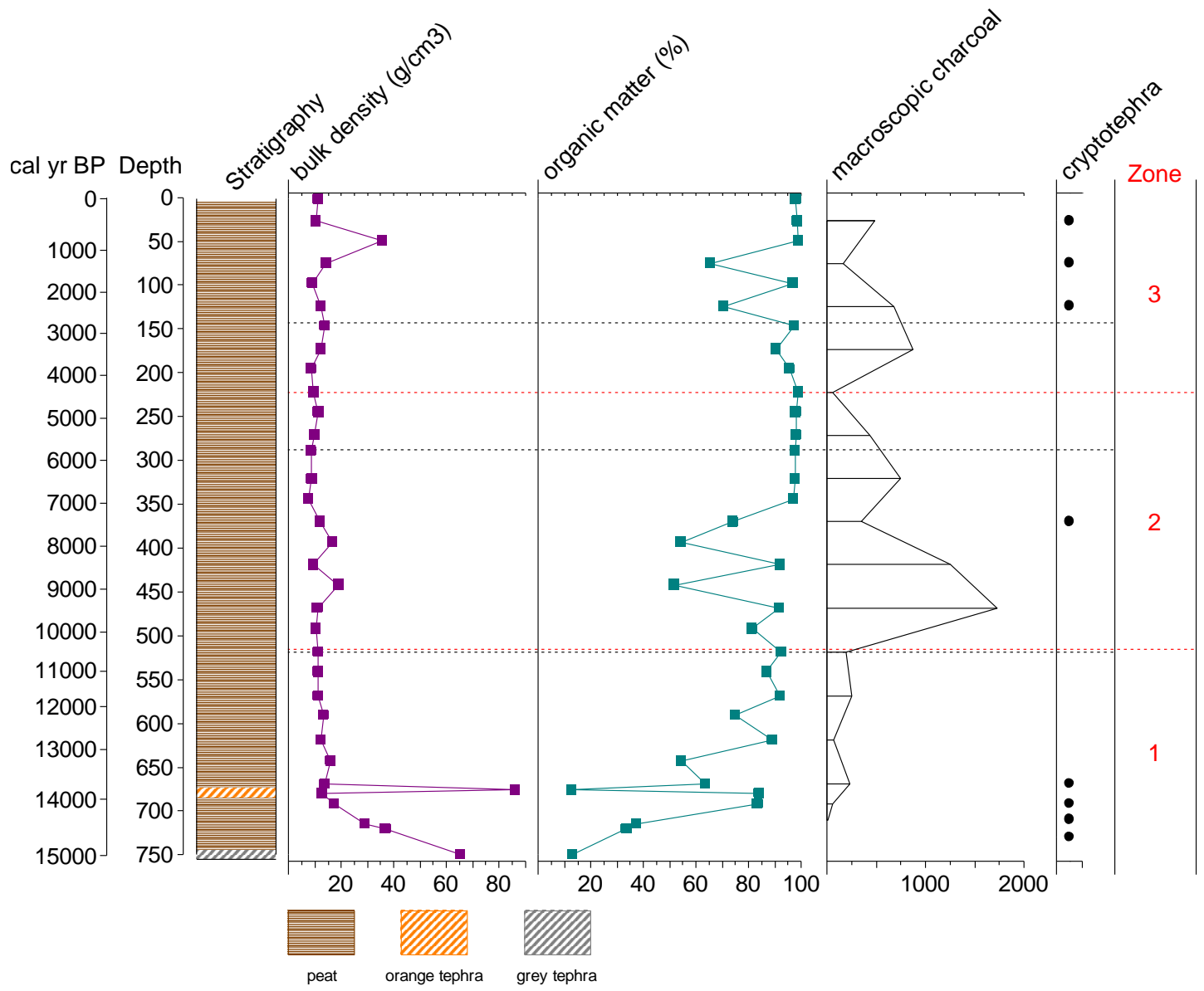

Figure 27: Bulk density (values exaggerated x100) and LOI results for the whole core. Additionally, the presence of confirmed cryptotephra is marked next to the macroscopic charcoal record. Red dashed lines indicate different zones, black dashed lines indicate location of sampling at fine resolution

Although results for bulk density and LOI analysis were presented in Figure 26 alongside the results from the plant cuticle and plant macrofossil analysis, they are examined in greater detail in Figure 27. Even with a scale exaggeration of $x 100$, it is clear that bulk density did not change much throughout the whole core. Indeed, bulk density only fluctuates very slightly around an average of $0.18 \mathrm{~g} / \mathrm{cm}^{3}$, implying consistent rates of deposition, compaction and decomposition throughout the sequence, except for around tephra layers. In general, increases of bulk density and decreases of organic matter values appear to correlate with each other quite well, which is especially obvious around $680 \mathrm{~cm}$ and below $700 \mathrm{~cm}$ depth indicating a relationship with the visible tephra layers. A marked spike of bulk density corresponds to samples with a reduced percentage of organic matter at $680 \mathrm{~cm}$, also coinciding with the orange tephra layer. Below $700 \mathrm{~cm}$ depth, the amount of organic matter in the samples decreases whereas bulk density values increase to the same 
extent, ending with the bottom most sample from $750 \mathrm{~cm}$ depth corresponding with the grey tephra layer. LOI results across the whole core average approximately $78 \%$ organic matter but display greater variability than bulk density values. These fluctuations are most pronounced in $\mathrm{Z1}$, whereas they level out in both other zones. Additionally, the average percentage of organic matter in $\mathrm{Z3}$ and $\mathrm{Z} 2$ is about $87 \%$ implying a significant change in peat composition occurred at the transition from the bottom zone to the middle zone. Errors for the triplicate samples from both batches of analyses at coarse resolution were around 5\% (relative standard deviation) for bulk density and $10 \%$ (relative standard deviation) for LOI.

\subsection{Results at fine resolution}

Based on the calculated peat accumulation rate (Chapter 4.1), each sample over a 1$\mathrm{cm}$ long segment represents peat accumulation of approximately 20 years. Finer resolution sampling would have been preferable as some plant species respond to fire events on the bog surface on a much shorter timeframe of about 2-5 years (Chapter 2.5.2). However, further reducing the sampling resolution was not possible. Sampling over the 1-cm segment yielded just enough material for both accurate plant macrofossil and subsequent bulk density and LOI analyses. As for analysis at coarse resolution, a description based on visual observations under the dissecting microscope was produced (Table 12). All F3B samples lacked glass shards, consistent with the analysis of this section of the core at coarse intervals (Table 10). Restiad cuticles however, were present in all eight samples. Plant remains were less well preserved in the samples containing the fire event as well as immediately before and after the fire event. All samples from F6A contained glass shards, except for the sample containing the fire event. This observation stands in contrast with the lack of glass shards observed from samples from this section of the core at coarse resolution (Table 10), highlighting the value of fine resolution sampling. At coarse resolution no restiad cuticles were obvious under the dissecting microscope from this section of the core, whereas F6A samples before the fire and F6A samples including the fire event contained some restiad cuticles, though very fragmented and in very small numbers. Although plant remains in all samples from F2A were not as well preserved as in the other two fine resolution analyses, remains were very abundant. Additionally, restiad cuticles were observed in all eight samples under the dissecting microscope. 
Table 12: Description of remains at fine resolution $(0=$ no/ not present; $+=$ very few remains and fragmented; $+=$ some/ small and fragmented; $++=$ many; green = good plant preservation; yellow $=$ medium plant preservation; red $=$ poor plant preservation)

\begin{tabular}{|l|l|l|c|c|c|}
\hline $\begin{array}{l}\text { Age (cal } \\
\text { yr BP }\end{array}$ & $\begin{array}{l}\text { Depth } \\
\text { (cm) }\end{array}$ & Sample & $\begin{array}{l}\text { Glass } \\
\text { shards }\end{array}$ & $\begin{array}{l}\text { Restiad } \\
\text { cuticles }\end{array}$ & $\begin{array}{l}\text { Amount of } \\
\text { remains }\end{array}$ \\
\hline 2667 & 139 & F2A -4 & 0 & + & ++ \\
\hline 2688 & 140 & F2A -3 & 0 & + & ++ \\
\hline 2710 & 141 & F2A-2 & 0 & + & ++ \\
\hline 2731 & 142 & F2A -1 & ++ & + & ++ \\
\hline 2752 & 143 & F2A 0 & + & + & ++ \\
\hline 2774 & 144 & F2A +1 & + & ++ & ++ \\
\hline 2795 & 145 & F2A +2 & + & ++ & ++ \\
\hline 2817 & 146 & F2A +3 & + & + & ++ \\
\hline
\end{tabular}

\begin{tabular}{|l|l|l|c|c|c|}
\hline $\begin{array}{l}\text { Age (cal } \\
\text { yr BP }\end{array}$ & $\begin{array}{l}\text { Depth } \\
(\mathbf{c m})\end{array}$ & Sample & $\begin{array}{l}\text { Glass } \\
\text { shards }\end{array}$ & $\begin{array}{l}\text { Restiad } \\
\text { cuticles }\end{array}$ & $\begin{array}{l}\text { Amount of } \\
\text { remains }\end{array}$ \\
\hline 5621 & 282 & F3B -4 & 0 & ++ & + \\
\hline 5642 & 283 & F3B -3 & 0 & + & + \\
\hline 5663 & 284 & F3B -2 & 0 & + & ++ \\
\hline 5683 & 285 & F3B -1 & 0 & + & ++ \\
\hline 5704 & 286 & F3B 0A & 0 & ++ & ++ \\
\hline 5725 & 287 & F3B 0B & 0 & ++ & + \\
\hline 5746 & 288 & F3B +1 & 0 & ++ & ++ \\
\hline 5768 & 289 & F3B +2 & 0 & ++ & ++ \\
\hline
\end{tabular}

\begin{tabular}{|l|l|l|c|c|c|}
\hline $\begin{array}{l}\text { Age (cal } \\
\text { yr BP }\end{array}$ & $\begin{array}{l}\text { Depth } \\
(\mathbf{c m})\end{array}$ & Sample & $\begin{array}{l}\text { Glass } \\
\text { shards }\end{array}$ & $\begin{array}{l}\text { Restiad } \\
\text { cuticles }\end{array}$ & $\begin{array}{l}\text { Amount of } \\
\text { remains }\end{array}$ \\
\hline 10291 & 510 & F6A -4 & + & 0 & ++ \\
\hline 10312 & 511 & F6A -3 & ++ & 0 & ++ \\
\hline 10333 & 512 & F6A -2 & + & 0 & ++ \\
\hline 10354 & 513 & F6A -1 & + & $(+)$ & + \\
\hline 10376 & 514 & F6A 0 & 0 & $(+)$ & + \\
\hline 10397 & 515 & F6A +1 & + & $(+)$ & ++ \\
\hline 10414 & 516 & F6A +2 & + & $(+)$ & ++ \\
\hline 10437 & 517 & F6A +3 & + & $(+)$ & ++ \\
\hline
\end{tabular}

\subsubsection{Plant cuticle and plant macrofossil analysis}

Figures 28 to 30 display the results of the plant macrofossil and plant cuticle analysis at fine resolution for the three chosen charcoal layers, respectively. Analysis F6A (Fig. 28) was identified via a peak in microscopic charcoal particles at a depth of 515 $\mathrm{cm}$. However, macroscopic charcoal particles were found at $514 \mathrm{~cm}$ depth indicating slight compaction of the drive as discussed in Chapter 3.3.1.1. Nevertheless, the peak in macroscopic charcoal provides evidence for the occurrence of a local rather than a regional fire (Chapter 2.5.1). A peak in microscopic charcoal particles at $288 \mathrm{~cm}$ was used for the second analysis, F3B (Fig. 29). As with the previous charcoal layer F6A, macroscopic charcoal particles were found in abundance stratigraphically above at $286 \mathrm{~cm}$, therefore also indicating a local fire on the bog surface. Analysis F2A (Fig. 30) was identified via a peak in microscopic charcoal particles at $143 \mathrm{~cm}$ as well as 
the discovery of macroscopic charcoal particles at the same depth. These did not coincide with a peak in counted macroscopic charcoal particles at the same depth, thus suggesting a regional fire in the surrounding area. In fact, counts of macroscopic charcoal particles were slightly higher before and after the recorded peak in microscopic charcoal particles. A trend observed in all three charcoal layers was the drop in fern sporangia in the samples containing the assumed local and even regional fire event. Increases in the number of fern sporangia were counted before and after each fire. Additionally, numbers of Gleichenia cuticles peaked before and during the fires in all three layers and subsequently decreased in abundance after the fire event. In accordance with descriptions of the whole core at coarse resolution (Table 10), sedges dominated the vegetation assemblage of all eight samples of analysis F6A (Fig. 28) and did not display any obvious response to the fire event. The vegetation assemblage of analysis F2A (Fig. 30) and F3B (Fig. 29) however, showed a response to the regional and local fire event, respectively. Both display a peak of cuticles from the 'others' category in the samples containing the fire event. Additionally, the number of Empodisma cuticles increases in both layers after the fire. 


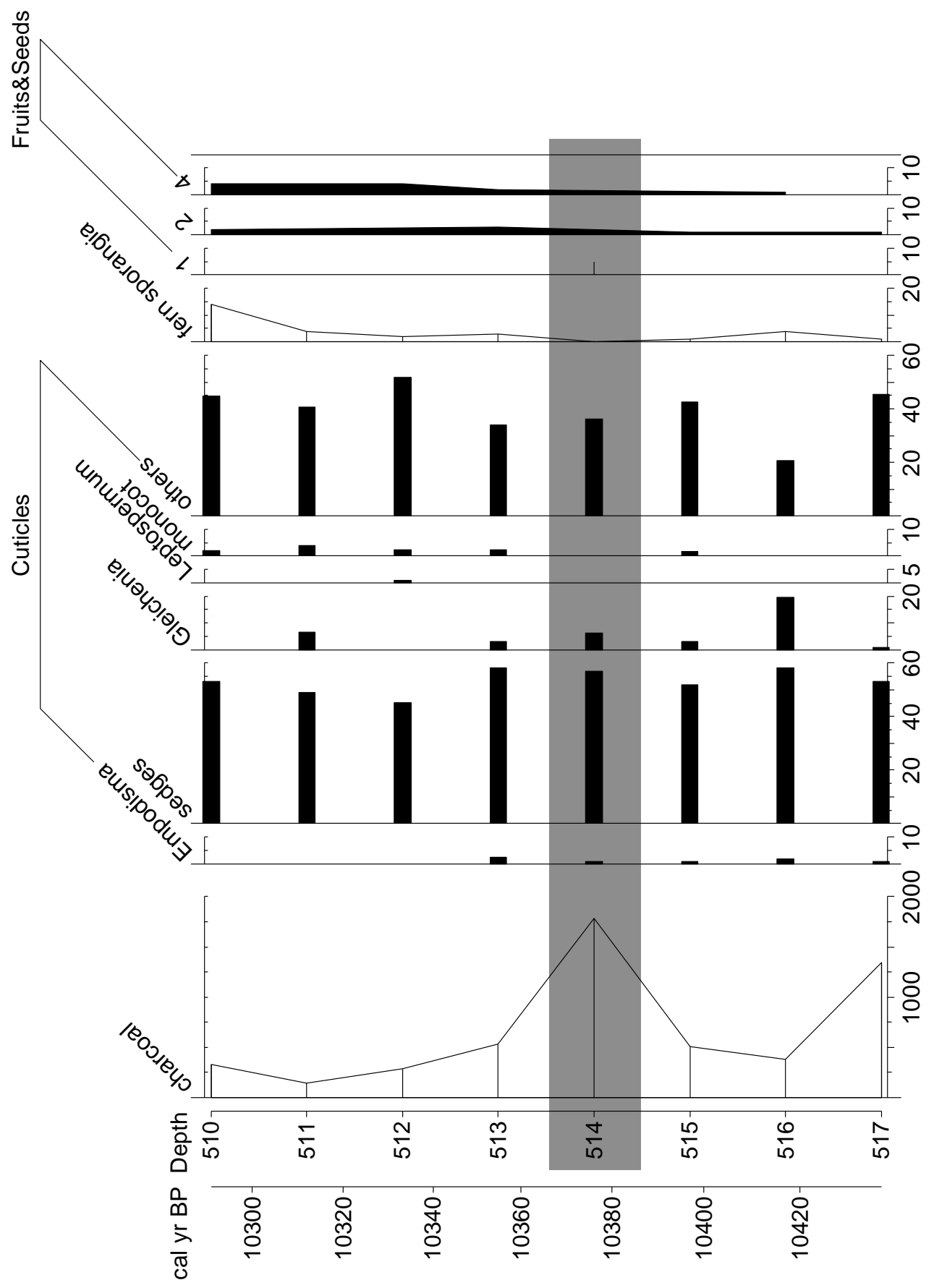

Figure 28: Results of plant cuticle and plant macrofossil analysis at fine resolution for layer F6A. Plant cuticle results are given in percent of the total counted cuticles, all other results are given as number of specimens. Shaded area marks the fire event. 


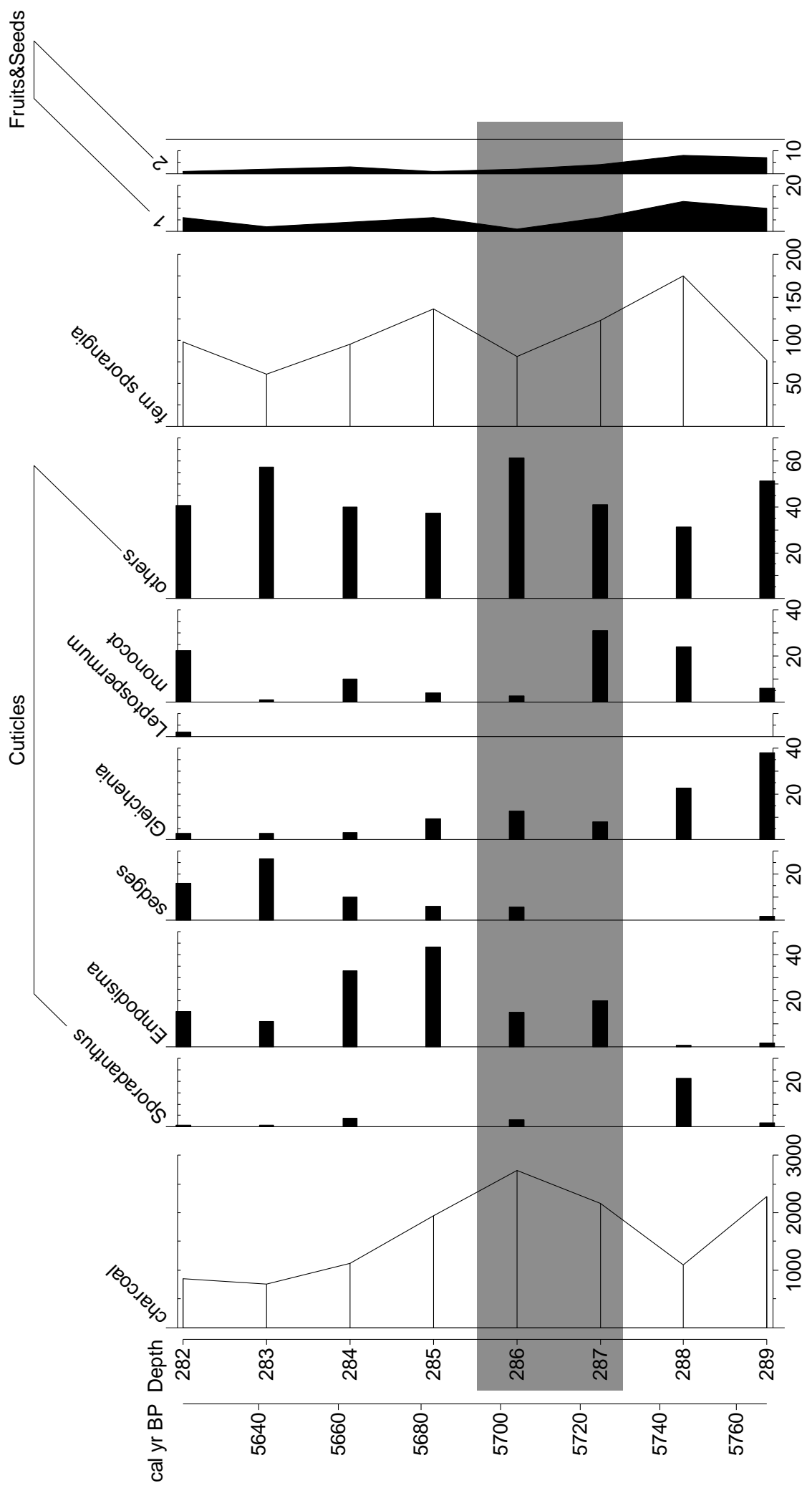

Figure 29: Results of plant cuticle and plant macrofossil analysis at fine resolution for layer F3B. Plant cuticle results are given in percent of the total counted cuticles, all other results are given as number of specimens. Shaded area marks the fire event. 


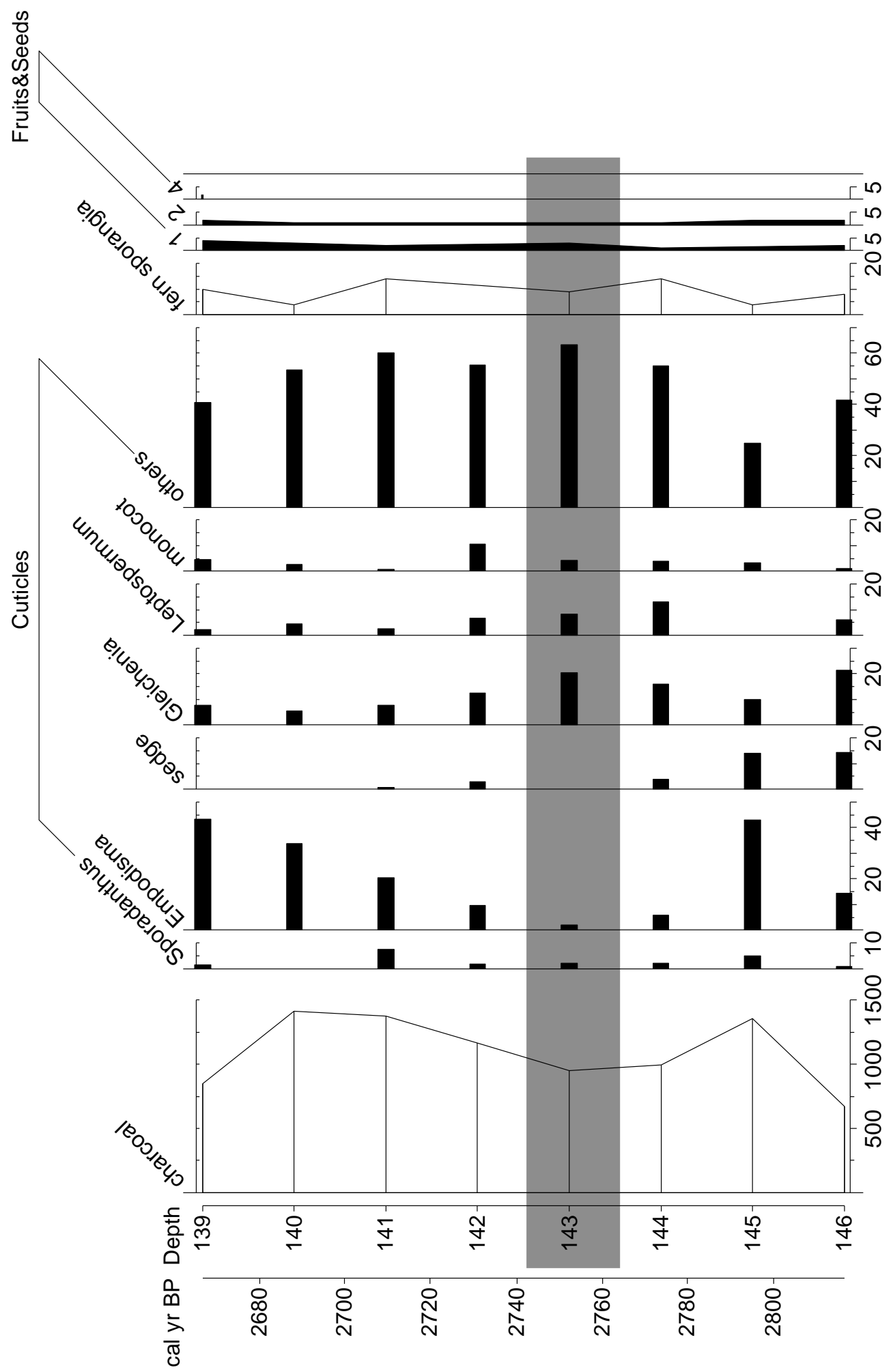

Figure 30: Results of plant cuticle and plant macrofossil analysis at fine resolution for layer F2A. Plant cuticle results are given in percent of the total counted cuticles, all other results are given as number of specimens. Shaded area marks the fire event. 


\subsubsection{Bulk density and LOI analyses}

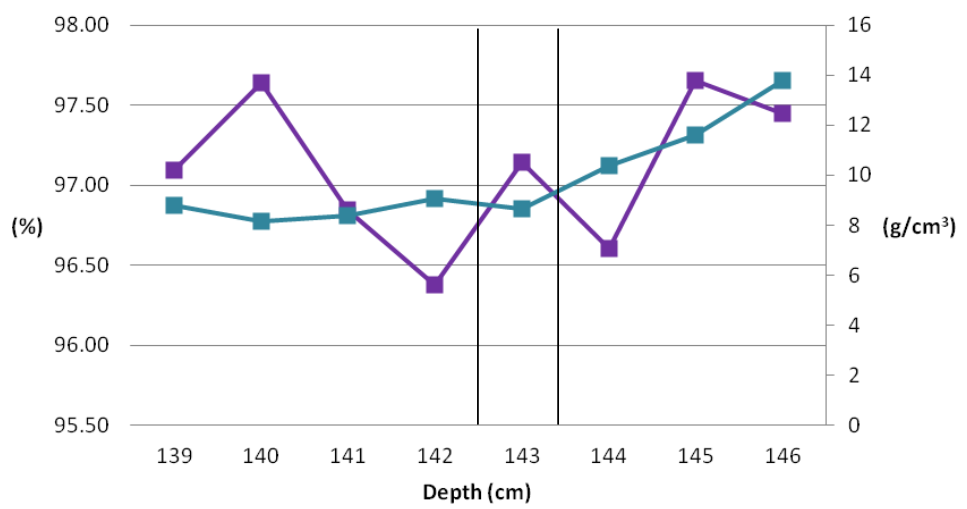

F2A

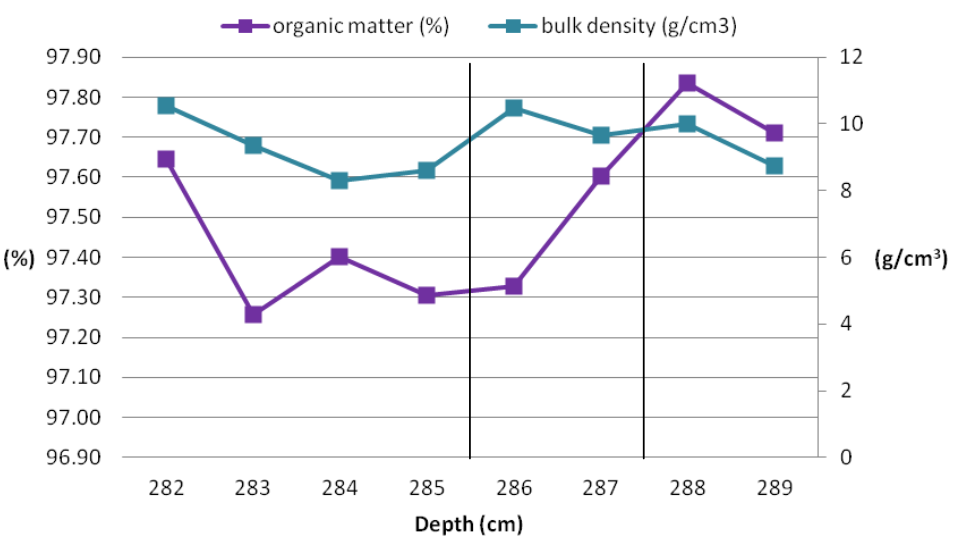

F3B

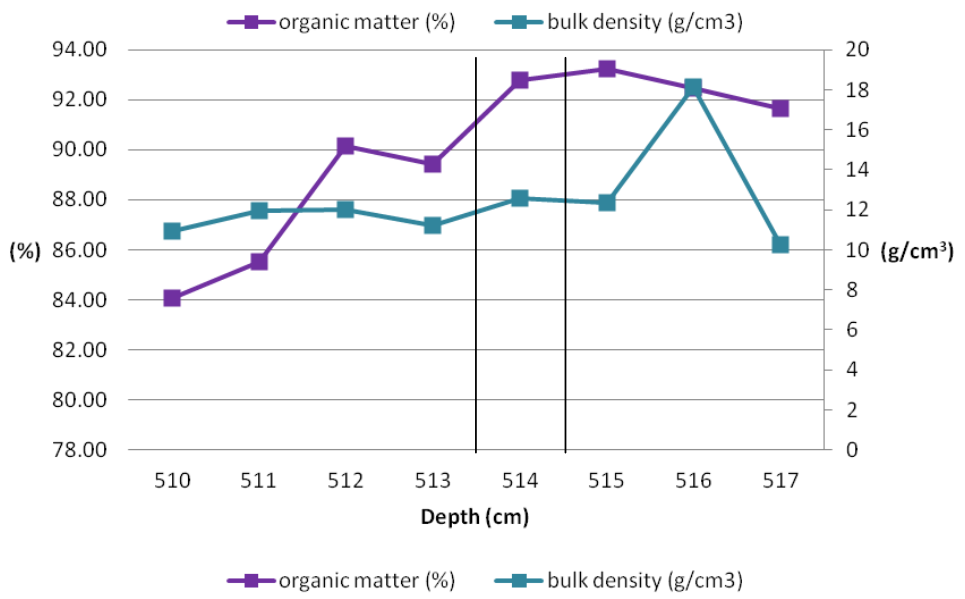

Figure 31: Bulk density (values exaggerated x100) and LOI results for fine resolution analysis, black lines mark peak in microscopic charcoal particles indicating the fire event

Figure 31 shows results from bulk density and LOI analyses at fine resolution for all three charcoal analyses: F2A, F3B and F6A. Organic matter consistently decreases slightly immediately after the burning event. Additionally, in two out of three cases (F2A and F3B), the amount of organic matter seems to recover eventually after the fire. Organic matter values of F6B were consistently lower than in both other analyses representing its' location in the sedge-dominated older zone of the bog. The 
error of the triplicate sample from this batch of analyses was $\sim 4 \%$ (relative standard deviation) for bulk density and $\sim 10 \%$ (relative standard deviation) for LOI.

\subsection{Summary}

Together, all results at coarse resolution point to a successional development for Moanatuatua Bog that can be divided into three parts with different vegetation assemblages. The oldest zone, Z1 (10477 - $14985 \mathrm{cal}$ yr BP), is dominated by sedges and lacks the presence of any restiad cuticles. It is also the zone that displays the largest changes in both bulk density and organic matter values. Z2, comprising the period from 4390 - 10477 cal yr BP, is described as a transitory stage towards Z3 (0 -4390 cal yr BP), which is dominated by restiads. Results from the analysis at fine resolution are not as straightforward to analyse, but nevertheless provide information about the suitability and applicability of the method, which will be further discussed in the next chapter. 


\section{DISCUSSION}

In this chapter, the method and its results at coarse and fine resolution are discussed with regards to the objectives outlined in Chapter 1.2. Results at coarse resolution are evaluated in the context of theories of raised bog development and compared to a pollen record, independently developed by Ignacio Jara (VUW) for the same sequence. Then, results at fine resolution are discussed and compared to a modern fire study. The final section focuses on the methodological advantages and problems encountered with plant subfossil cuticle analysis at Moanatuatua Bog, followed by recommendations for further work.

\subsection{Bog development during the Holocene $\left(2^{\text {nd }}\right.$ objective $)$}

The goal of the second objective was to apply plant cuticle analysis at coarse resolution across the whole length of the core to reconstruct changes in the local vegetation assemblage during the Holocene and then compare it to an independently obtained pollen record for the same sequence. Results from the analysis at coarse resolution show a transition of the vegetation assemblage in three steps (Fig. 25, Chapter 5.1.1). Table 13 gives a summary of those findings and highlights the main vegetation composition and successional stages of the bog:

Table 13: Holocene vegetation and bog development of Moanatuatua Bog based on plant macrofossil analysis

\begin{tabular}{|c|c|c|c|c|}
\hline ZONE & $\begin{array}{l}\text { DEPTH } \\
(\mathrm{cm})\end{array}$ & $\begin{array}{l}\sim \text { AGE } \\
(\text { cal yr BP })\end{array}$ & VEGETATION & $\begin{array}{l}\text { SUCCESSIONAL } \\
\text { STAGE }\end{array}$ \\
\hline 3 & \multirow{3}{*}{$\begin{array}{l}222 \\
519\end{array}$} & \multirow[b]{2}{*}{4400} & restiad-dominated & \multirow{3}{*}{$\begin{array}{l}\text { raised bog } \\
\text { bog } \\
\text { fen/swamp } \\
\text { swamp forest }\end{array}$} \\
\hline 2 & & & transition between sedges and restiads & \\
\hline 1 & & 1500 & sedge-dominated & \\
\hline
\end{tabular}

\subsubsection{Changes during the Holocene}

Based on plant cuticle, plant macrofossil and bulk density as well as LOI analyses, at the coring site, Moanatuatua Bog started as a swamp forest and subsequently developed into a fen, bog and raised bog. 


\section{Zone 1: Transition from swamp forest to fen}

The appearance of root nodules and the lack of any other plant remains in the two basal samples (1201R8A at $710 \mathrm{~cm}$ and 1201R8A at $730 \mathrm{~cm})$, indicates the occurrence of a swamp forest at the coring site during the very early stages of bog inception (Fig. 25). Furthermore, the high amount of cuticles in the 'others' category in this section could be another indicator for the presence of a swamp forest. Conifer cuticles, indicating a forested vegetation assemblage, are generally well-preserved, especially in the proposed high water-level conditions of a swamp forest. However, due to a lack of forest cuticle reference material, these were not able to be identified (pers. comm. Aline Homes). A swamp forest phase was also suggested for the early development of Kopouatai Bog (Newnham et al., 1995), attributed to poor drainage conditions and the occurrence of regular floodings. Counts of microscopic charcoal particles were very low in early stages of bog development, consistent with low amounts of both macroscopic and microscopic charcoal particles at Moanatuatua Bog. A deterioration in drainage conditions at Kopouatai Bog around $10300 \mathrm{yr}$ BP resulted in the transition to a fen. Similar subsequent processes are proposed for Moanatuatua Bog. After root nodules disappeared from the samples (stratigraphically above sample 1201R8A at $710 \mathrm{~cm}$ ), the presence of sedge cuticles indicates the transition from a swamp forest to fen conditions as sedges allow sediment entrapment, which enables fen peat accumulation. Consequently, Z1 was dominated by sedges, which almost made up the majority of the vegetation assemblage (Fig. 25). The transition to fen conditions is furthermore accompanied by decreasing bulk density values and higher, but markedly fluctuating organic matter content as shown in Figure 26. Such conditions are common for fens as they are typically prone to flooding and/or seasonal hydrological changes due to their connection to the groundwater system. Therefore, minerogenic material can easily be washed in, which results in the varying LOI values.

Zone 2: Transition from sedge-dominated to restiad-dominated vegetation assemblage

Over time, the cumulative build-up of peat serves to mitigate these hydrological fluctuations as the fen progressively develops into a bog and subsequently a raised bog (Chapter 2.3.1). At Moanatuatua Bog, this transition can be seen in the plant cuticle and the plant macrofossil record, as well as in the changes in bulk density and organic matter results (Fig. 26 and Fig. 27). Correlating with a significant increase in 
macroscopic charcoal particles at around 10500 cal yr BP, the amount of sedges reduces substantially throughout Z2. Then, Empodisma followed by Sporadanthus cuticles appear in the record. With the onset of bog conditions, the establishment of restiad species and the appearance of other plant species such as Gleichenia and Leptospermum, a more stable and productive vegetation community develops (Fig. 26). $\mathrm{Z} 2$ is characterised by rather stable and more importantly higher LOI values as now any minerogenic material can only be deposited on the bog surface by wind. As the increase in macroscopic charcoal particles, starting at $10500 \mathrm{cal} \mathrm{yr} \mathrm{BP}$, correlates with the transition from $\mathrm{Z} 1$ to $\mathrm{Z} 2$ and the subsequent dominance of restiads (Fig. 26), it can be speculated whether larger and more frequent fires either caused or were a result of this transition. Fletcher et al. (2014) describe a transition from a forested Cyperaceae-Sphagnum wetland to a non-forested restiad-dominated wetland in north-central Tasmania. The paper argues the transition was driven by a large and catastrophic fire. Fletcher et al. (2014) describe a transition from a forested Cyperaceae-Sphagnum wetland to a non-forested restiad-dominated wetland in north-central Tasmania. The paper argues the transition was driven by a large and catastrophic fire. Fletcher et al. (2014) suggest that the fire was large enough to completely destroy the original forest vegetation and Cyperaceae-Sphagnum wetland, which allowed the invasion of the site by wetland species. Restiads were then able to continuously dominate the vegetation assemblage due to positive hydrological feedback mechanisms. The loss of forest vegetation resulted in the decrease of transpiration rates and the immediate establishment of peat-forming wetland plants tolerant of high water-tables thus increased soil waterlogging at the site. As a result, the re-establishment of trees was effectively prevented, resulting in the development of a restiad-dominated wetland and the appearance of shrubs of Leptospermum (Fletcher et al., 2014). Similar patterns are evident here for the transition from $\mathrm{Z} 1$ to $\mathrm{Z} 2$ at Moanatuatua Bog, where the replacement of sedges with restiads, Gleichenia and Leptospermum coincided with a rise in macroscopic as well as microscopic charcoal particles (Fig. 26 and Fig. 32), indicating large local fire events on the bog surface at the transition from a sedge-dominated fen to a restiaddominated raised bog. Fletcher et al.'s (2014) results are based on pollen data and Cyperaceae pollen can pose a problem with regard to reconstructing vegetation assemblages (Chapter 5.1.2). This can be especially critical when a significant proportion of data is made up by Cyperaceae pollen as is the case with the study 
from Tasmania. Additionally, the climate at the Tasmanian site is described as humid and fires were not reported as being more frequent after the transition to the restiaddominated wetland (Fletcher et al., 2014). At Moanatuatua Bog macroscopic as well as microscopic charcoal particles and peaks were consistently more abundant in Z2 than in Z1, suggesting an increase in fire intensity and frequency (Fig. 32). The increased frequency of fires can be explained with climatic changes, the susceptibility of raised bogs to fires in summer months (Stanway \& Clarkson, 1994; Charman et al., 2009) (Chapter 2.5.1) and the strong relationship of restiads with fire-prone landscapes (Newnham et al., 1995; de Lange et al., 1999). Due to the coarse sampling resolution, it cannot be determined whether the increase in macroscopic and microscopic charcoal particles preceded the transition to a restiaddominated bog.

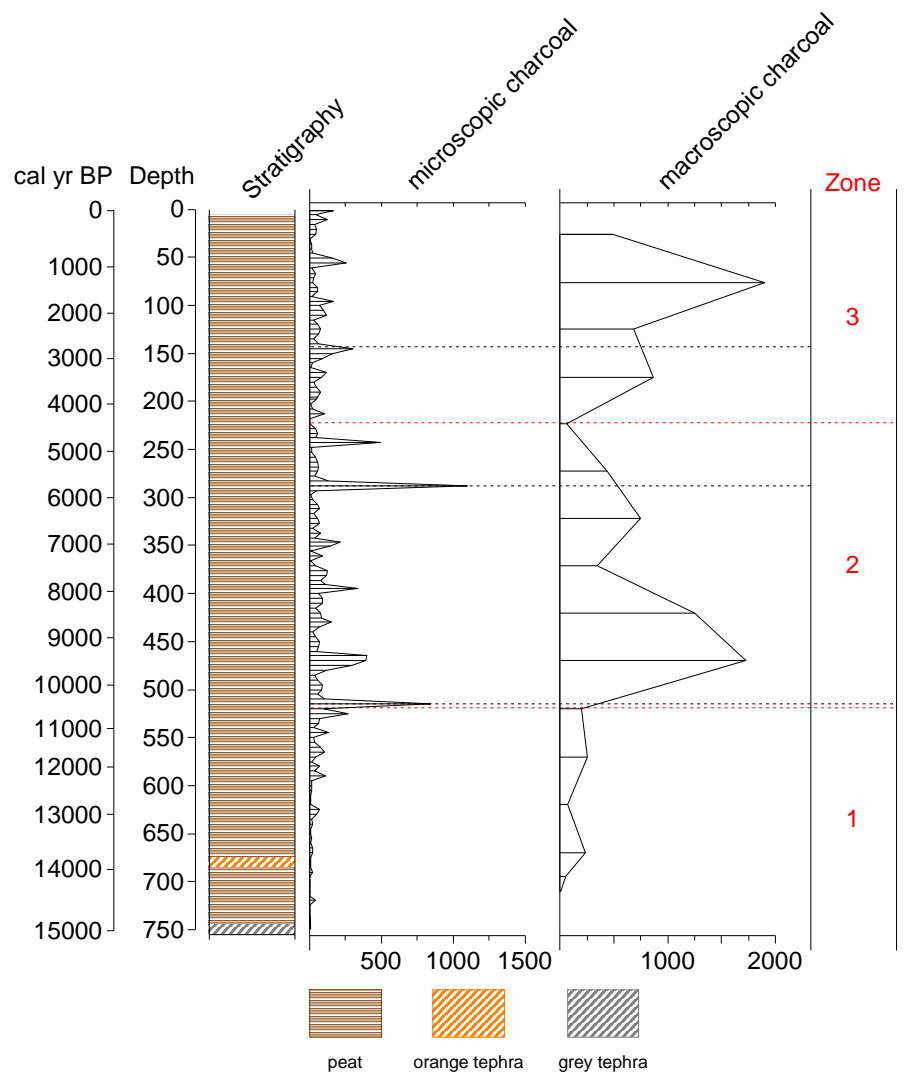

Figure 32: Macroscopic and microscopic (data obtained by Ignacio Jara, VUW) charcoal record. Red dashed lines indicate different zones, black dashed lines indicate location of sampling at fine resolution.

\section{Zone 3: Restiad-dominated vegetation assemblage}

As a result of the continued persistence and expansion of restiad species, a domed surface established, which is raised above the surrounding terrain. By now, water levels were even more stable as the bog became dependent upon rainfall for its water supply. Z3 is therefore dominated by restiads with occasional Leptospermum and 
Gleichenia cuticles, whereas sedges are almost entirely absent (Fig. 26). Interestingly, fern sporangia reach their highest abundance in this section, although Gleichenia cuticles, the likely candidate for the sporangia, are not present in the same magnitude and distribution. The reason for this imbalance might be that fern sporangia are wind-blown from other parts of the bog, whereas cuticles record local conditions at the coring site. Another notable point is the proposed association of macrocharcoal peaks with higher amounts of restiad cuticles (Fig. 26). This relationship seems contradictory as charcoal peaks would be assumed to indicate drier conditions whereas both Empodisma and Sporadanthus are regarded as indicators of wet conditions on the bog surface (Table 4). On the other hand, a peak in macroscopic charcoal particles can point to drier summer conditions (Charman et al., 2009) as this would result in a strong drawdown of water-tables. At raised bog locations, this causes the bog surface to dry out, which is then very susceptible to fire events. Extensive raised bogs would therefore be prone to large fires on the bog surface.

Summary: Moanatuatua Bog development follows successional model

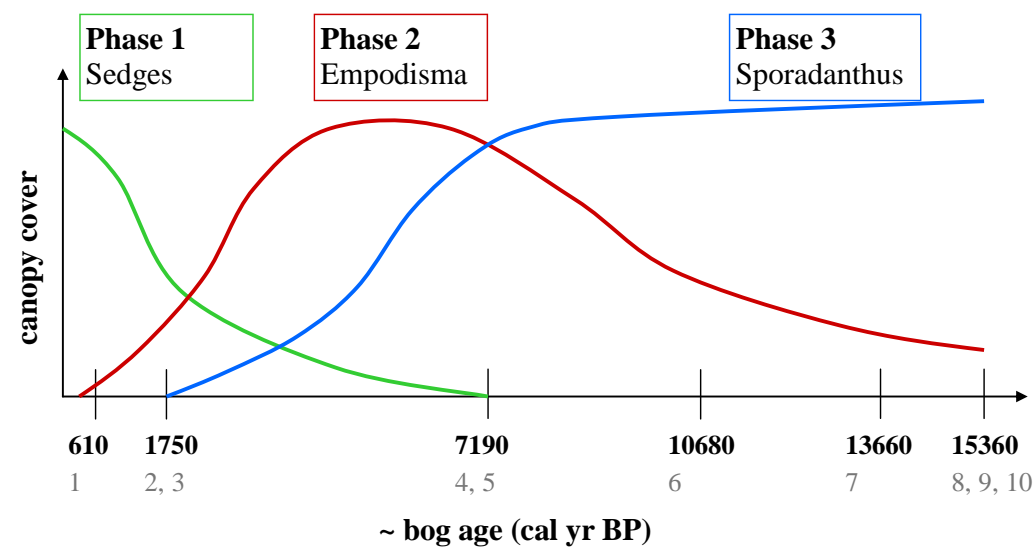

Figure 33: Succession model of restiad bogs. The timeframe for successional change is estimated based on the vegetational pattern of different aged bogs $(1=$ Duck Creek, $2=$ Whangamarino, $3=$ Opuatia, 4 = Torehape, $5=$ Kopuatai (northern part); $6=$ Lake Maratoto, $7=$ Kopuatai (southern, main part), $8=$ Te Mimiha, $9=$ Moanatuatua North, 10 = Moanatuatua); (modified from Clarkson et al., 2004)

As described in Chapter 2.4.2, bog development follows a certain successional model. As can be seen from Figure 33 and Table 4, the established developmental stages of Moanatuatua Bog generally follow this schematic successional model. The record of plant cuticles clearly shows the first sedge-dominated vegetation zone with subsequent dominance of restiad species. At Moanatuatua Bog, synchronous with the model, Empodisma established first with Sporadanthus being the late-successional 
species. Additionally, a strong relationship of vegetation assemblages with the intensity and frequency of fires on the bog surface can be observed.

\subsubsection{Comparison of plant cuticle record with pollen record}

Figure 34 displays a comparison of the main plant species of Moanatuatua Bog as recorded by subfossil plant cuticles with the pollen record obtained for the same sequence by Ignacio Jara (VUW). A pollen-only diagram can also be found in Appendix 4.2. 


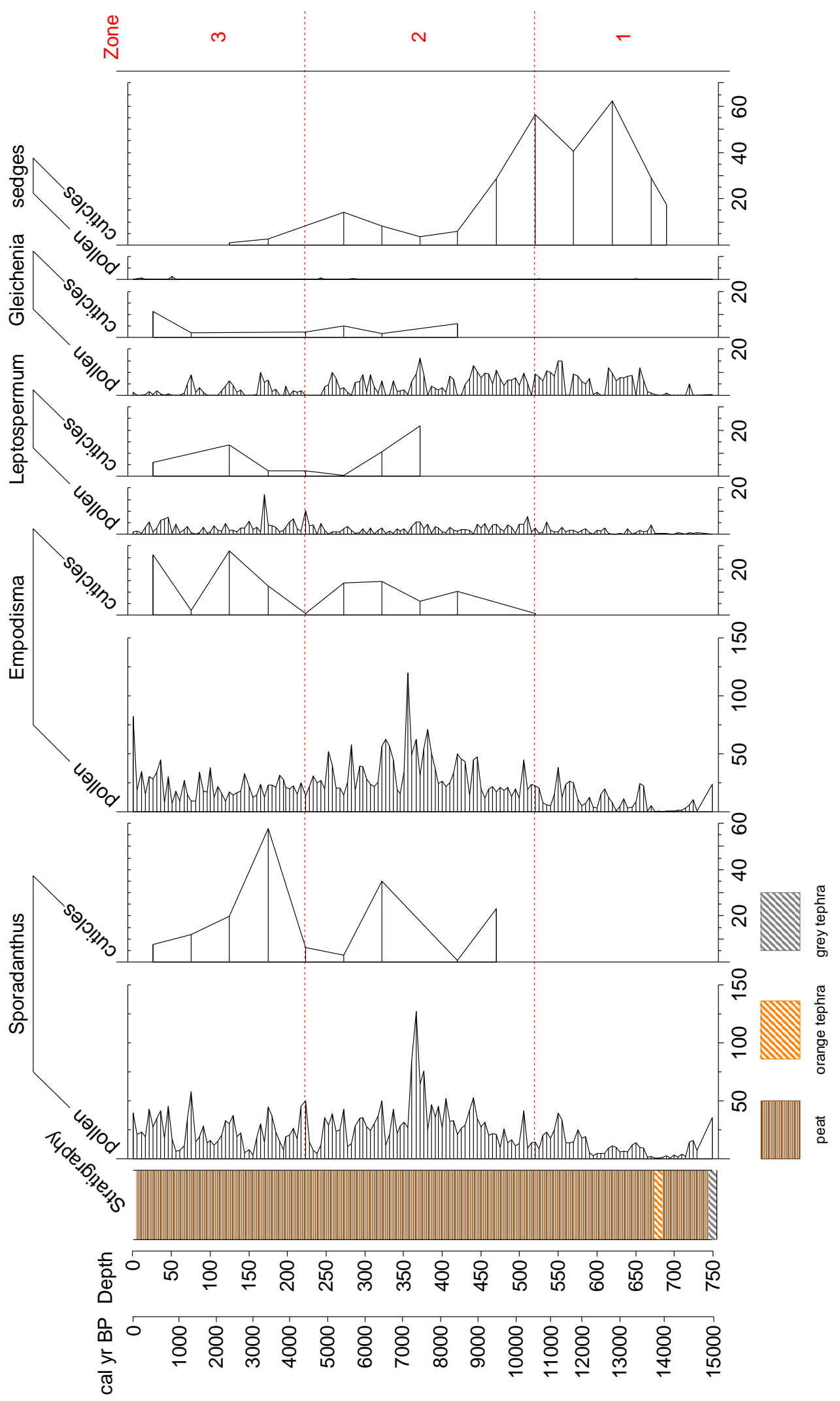

Figure 34: Comparison of main plant species as recorded by plant cuticles and pollen (pollen data obtained by Ignacio Jara, VUW). Red dashed lines indicate different zones. 
The pollen record and the cuticle record differentiate in the abundance and presence of both restiad species. Pollen of Sporadanthus and Empodisma is recorded throughout the whole sequence, whereas cuticles of each can only be found in $\mathrm{Z} 3$ and Z2. Pollen is representative of the regional vegetation assemblage whereas cuticles are a record of the local and in-situ vegetation of the bog, which can be explained by the different dispersal pathways of pollen and cuticles. Thus, the pollen record could have recorded the initiation of a restiad-dominated vegetation assemblage somewhere on the then extensive fen area. Yet, at the coring site itself, development of a restiad bog might have taken a while longer. At Kopouatai Bog, for example, there is macrofossil evidence for the existence of a swamp forest that is intercepted by small mires in the early stages of bog development (Newnham et al., 1995). Small patches of bog vegetation could therefore deliver regional pollen to an otherwise sedge cuticle-dominated local record. Especially, pollen of Sporadanthus as a tall plant is considered to be transported rather far from the parent plant (pers. comm. Aline Homes). From this it may be inferred that whereas restiad communities first developed at the core site at $\sim 10500 \mathrm{cal}$ yr BP, they must have persisted for several thousand years before that elsewhere on the bog.

The major advantage of the cuticle record, is the easy and reliable distinction between Empodisma and Sporadanthus cuticles. Restiad pollen, on the other hand, is very hard to differentiate due to the gradational change of distinct features. Empodisma, for example, is considered to be slightly bigger than Sporadanthus and to have a thicker wall. Identifications based on these features are however, difficult and some restiad pollen can therefore only be categorised as Restionaceae (Newnham et al., 1995). As discussed, Empodisma and Sporadanthus cuticles on the other hand have stomatal complexes that are readily identifiable and able to be distinguished from one another (Chapter 4.2).

Another clear difference between the two records is the almost complete lack of sedge pollen (i.e. Cyperaceae pollen) throughout the whole sequence (Fig. 34). After analysing the plant cuticle record, a dominance of sedge and/or grass pollen was expected to be seen in the lowermost zone of the core. However, Cyperaceae pollen only occurs in very limited numbers and is mostly absent in the samples. Unlike the pollen - cuticle differences for the restiads, this disparity cannot be explained by 
different dispersal pathways. It is suggested that although wind-pollinated pollen, such as from sedges, is assumed to be rather abundant, it is not guaranteed to be well represented in pollen records (McQueen \& Macphail, 1983). The reason for the almost complete lack of Cyperaceae pollen in this study might lie in the low preservation potential of these pollen grains (pers. comm. Rewi Newnham). Due to a thin exine (outer layer), they are more fragile and structurally weak, which results in a higher susceptibility to degradation and decomposition. Pollen from sedges might therefore be poorly preserved in the depths of the peat deposit and under-represented in the record (Vuorela, 1973; Li et al., 2005). Sedge cuticles, on the other hand, were found to be well preserved in the peat deposits of Moanatuatua Bog, where they dominate the vegetation assemblage in $\mathrm{Z3}$.

Plant subfossil cuticle analysis can therefore deliver additional and complementary results to palynology. In the case of Moanatuatua Bog, the abundance of sedge cuticles in $\mathrm{Z3}$ provides clear evidence for the initiation of the bog as a fen, whereas the fen phase is not apparent from the pollen data alone (Fig. 34). It is therefore suggested that Cyperaceae pollen at Moanatuatua Bog (and potentially at other raised restiad bogs) is a less reliable indicator of sedge communities than the Cyperaceae cuticle record.

\subsubsection{Use of bulk density and organic matter to indicate tephra layers}

As with other Waikato restiad bogs (Newnham et al., 1995; Gehrels, 2009), Moanatuatua Bog contains tephra, yet individual distinct layers are not visible in the core, except for the orange and grey layers at around $680 \mathrm{~cm}$ and $750 \mathrm{~cm}$ depth, respectively (Fig. 27). This lack of visibility in the samples might be a result of the high amount of humic acids in the core, which can change the colour of tephra particles (pers. comm. Ignacio Jara, Rewi Newnham). Yet, tephra layers are recorded by increases in bulk density and decreases in organic matter (Fig. 27). The correlation between increases in bulk density and decreases in organic matter and their association with tephra concentrations was also made by Hazell (2004) for Moanatuatua Bog as well as Kopouatai Bog. Bulk density values (Fig. 27) throughout the whole core are nearly constant, which implies that decomposition rates did not undergo any major changes during the Holocene. Exceptions are the significantly higher results around the two obvious tephra layers at approximately 
$680 \mathrm{~cm}$ and $750 \mathrm{~cm}$ depth. Other increases in bulk density occur around $50 \mathrm{~cm}$ and between $400 \mathrm{~cm}$ and $450 \mathrm{~cm}$ depth. These deviations from the mean degree of compaction are only in the order of about $0.1 \mathrm{~g} / \mathrm{cm}^{3}$ and therefore considerably smaller in magnitude, which could indicate some other events on the bog surface, such as fires or dust and ash influx. Results from LOI analysis also provide evidence for the existence of the orange and grey tephra layers with significantly reduced values around $680 \mathrm{~cm}$ and $750 \mathrm{~cm}$ depth. Stratigraphically above these two tephra layers, organic matter shows more constant values. Four more horizons with reduced organic matter were identified at approximately $75 \mathrm{~cm}, 110 \mathrm{~cm}, 380 \mathrm{~cm}$ and $430 \mathrm{~cm}$ depth (Fig. 27). Three of these reductions in organic matter correlate with the findings of cryptotephra in the samples (Table 10; Table 12; Fig. 27) indicating tephra layers. No glass shards were obvious in the middle section of the sequence, yet organic matter was reduced at around $430 \mathrm{~cm}$ depth suggesting a disturbance on the bog surface other than tephra input. This also correlates with the poor preservation of plant remains in this section of the core (Chapter 5.3). 


\subsection{Response of vegetation to fire events ( $3^{\text {rd }}$ objective)}

Figure 34 presents a summary of the vegetation response pattern at Moanatuatua Bog recorded by Clarkson (1997) after a fire in 1972, as discussed in Chapter 2.5.2. It shows that by 22 years after the fire, original vegetation cover percentages and assemblages are restored. This response pattern follows the succession model (Fig. 33) proposed by Clarkson et al. (2004), only on a much faster timescale. Due to the adopted sampling resolution and the peat accumulation rate of Moanatuatua Bog, only few comparisons between the analysis at fine resolution (Fig. 36) and the modern study (Fig. 35) by Clarkson et al. (2004) can be made.

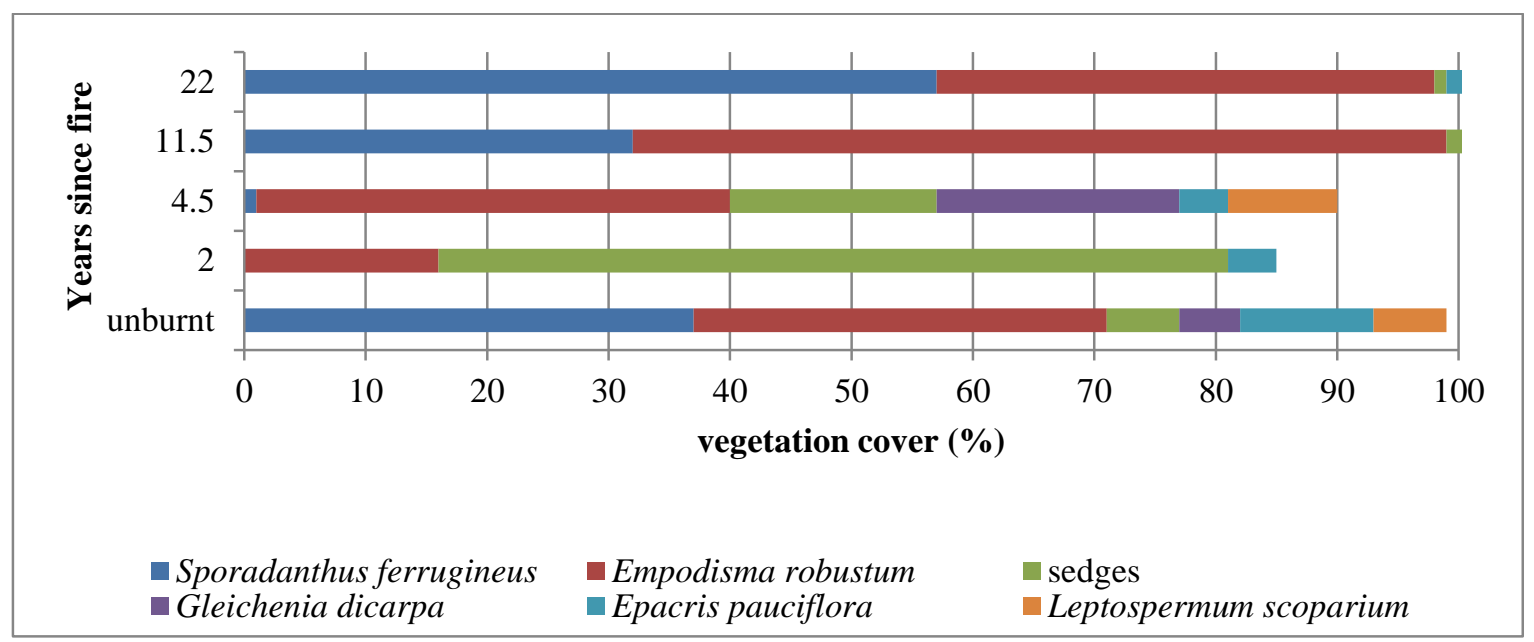

Figure 35: General vegetation cover trends of the main species at Moanatuatua Bog versus time since fire event (compiled from Clarkson, 1997) 


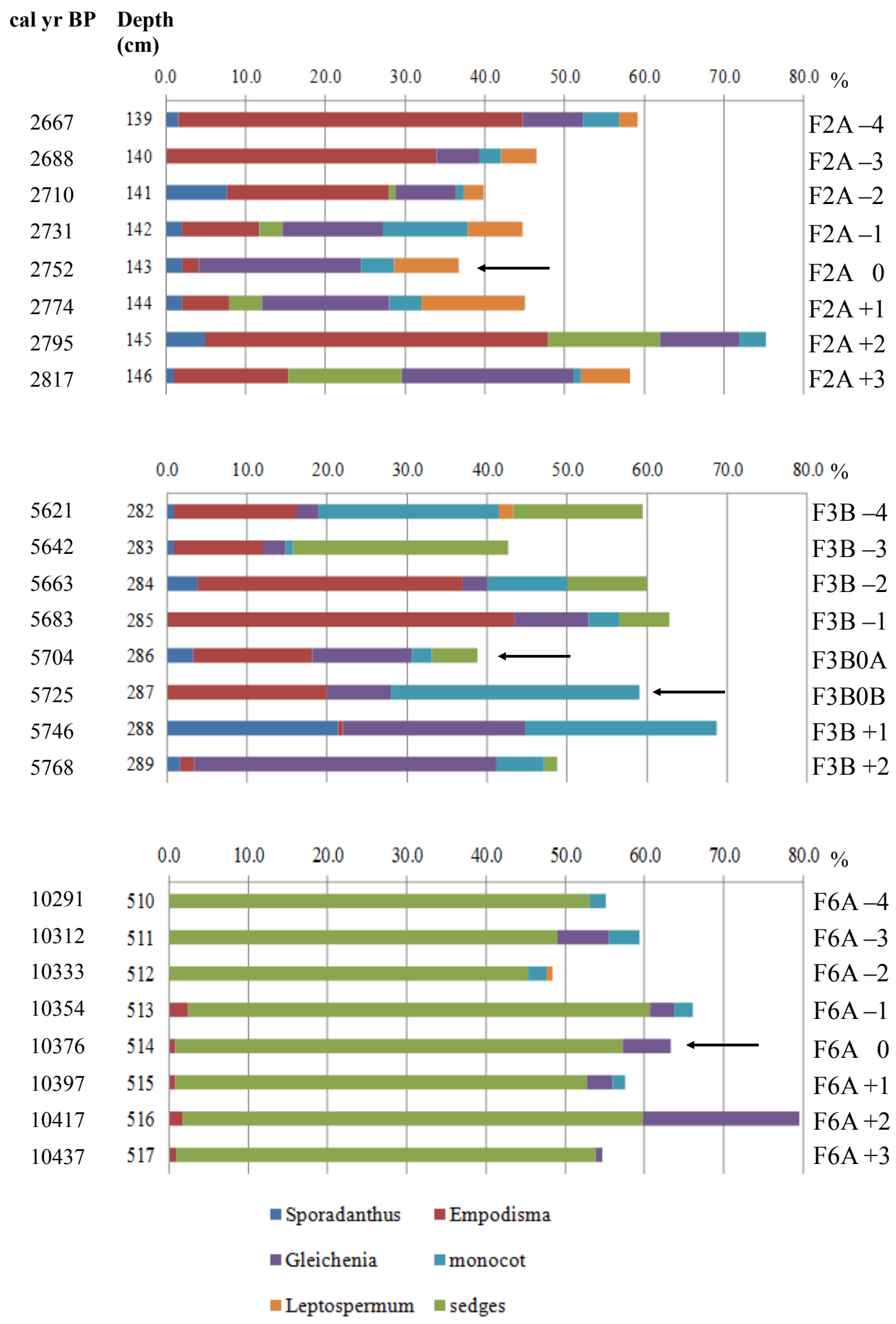

Figure 36: Summary of response of main plant species based on plant cuticles (percentage of abundance, remaining percentage to $100 \%$ is 'others' category) from all three analysed charcoal layers; black arrows indicate fire event 
The peak in macroscopic charcoal particles between $286 \mathrm{~cm}$ and $287 \mathrm{~cm}$ depth in layer F3B suggests a local fire event on the bog surface (Fig. 29). Immediately after the fire event at $285 \mathrm{~cm}$ depth (F3B -1), a peak in Empodisma cuticles was recorded (Fig. 36). As each sample is an amalgamation of approximately 20 years, this is consistent with the reported dominance of Empodisma by Clarkson et al. (2004) (Fig. 35). After another 20 years (sample at $284 \mathrm{~cm}$ depth; F3B -2) Sporadanthus is also present indicating a full recovery to raised bog vegetation assemblages. Therefore, analysis F3B recorded the expected vegetation response after a local fire on the bog surface. A possibility exists that F3B recorded another disturbance on the bog surface as indicated by the peak of Gleichenia cuticles and macroscopic charcoal at $289 \mathrm{~cm}$ depth $(\mathrm{F} 3 \mathrm{~B}+2)$. This is suggested due to the fact that Gleichenia favours establishment at times of disturbance on the bog surface (Newnham et al., 1995).

Due to a lack of macroscopic charcoal particles at the time of the proposed fire event, which was recorded by microscopic charcoal in analysis $\mathbf{F 2 A}$, it seems that no local fire event occurred but rather a regional fire (Fig. 30). The peak of Gleichenia cuticles at $143 \mathrm{~cm}$ depth (F2A 0; Fig. 36) however, suggests some type of disturbance even if no other indication in the form of macroscopic charcoal is given. Possible disturbances on the bog surface include fires, drying out or expansion of shrubs. Macroscopic charcoal particles could have been washed through to older layers, therefore giving no indication of local fire events (pers. comm. Aline Homes). Sampling immediately after the fire event in analysis F2A revealed a dominance of Empodisma but Sporadanthus was already present in the sample, which could be a result of a faster recovery process of Sporadanthus in this particular time period.

After analysing the results at coarse resolution (Fig. 26), it becomes clear that analysis F6A was conducted in the pre-restiad phase of Moanatuatua Bog. It therefore provides no new data concerning response processes or recovery times of fossil restiads at Moanatuatua Bog. Nevertheless, the approach offered interesting information that could be compared with other vegetation assemblages of the raised bog as the layer does record a local fire on the bog surface due to the peak of macroscopic charcoal particles. For example, no apparent response to the fire event can be seen in the plant assemblage (Fig. 36). The reason for the lack of a response pattern lies presumably in the immediate response of sedges, which is consistent with 
the theory of vegetation response presented in Chapter 2.5.2. Sedges are regarded as being able to resprout from protected below-ground plant parts, therefore dominating the bog surface in the first 2-3 years after the fire (Fig. 35). Due to the sampling resolution and the peat accumulation rate, the response of sedges could not be resolved in this study. Similar to analysis F3B, the abundance of Gleichenia and sedge cuticles at $516 \mathrm{~cm}$ depth $(\mathrm{F} 6 \mathrm{~A}+2)$ could indicate disturbance such as a drought on the bog surface even though macroscopic charcoal particles indicate no fire event.

In general, analysing fire response patterns and recovery times depends significantly on the accumulation rate of the bog as it defines the potential sampling resolution. In this study, results are blurred across a time interval of 20 years, which is marginal for tracing the ecological processes such as recovery time and response pattern (Chapter 5.3). However, two (F3B and F6A) out of the three analyses recorded local fires as indicated by macroscopic charcoal peaks (Fig. 29 and Fig. 28) and layer F3B actually displays the expected (Fig. 36) response pattern. Although F6A was done in the prerestiad phase it also delivers the expected results, bearing the sampling resolution and peat accumulation rate in mind. Apart from the response pattern of the vegetation, analysis F6A additionally highlighted the value of fine resolution sampling. It revealed glass shards in all samples, except for the one containing the fire event, whereas no glass shards were recorded in this section at coarse resolution. Due to the abundance of cryptotephra, it furthermore can be speculated that a volcanic eruption led to the recorded fire on the bog surface (Gehrels, 2009).

\subsection{Critical review of methodology $\left(1^{\text {st }}\right.$ objective)}

After discussing the results at coarse and fine resolution, objective one can be confirmed as achieved. A new method to retrieve, identify and quantify subfossil plant cuticles from Moanatuatua Bog and other raised restiad bogs has been developed and applied successfully. Especially at coarse resolution the coherence of the various proxies used in this study, act as a strong affirmation of the method as they are consistent with theories about how bogs grow and develop. The identification of an early sedge-dominated phase from cuticle analysis, when this phase is not evident in the pollen record, demonstrates the value of the method. The biggest constraint in the study however, is the time-resolution problem, where results depend largely on the sampling resolution adopted and the rate of peat accumulation 
at Moanatuatua Bog. In the fine-resolution analysis, based on the peat accumulation rate of $0.05 \mathrm{~cm} / \mathrm{yr}$, the adopted sampling resolution yielded samples every 20 years, i.e. each sample represents an amalgamation of 20 years of vegetation assemblage on the bog surface. Based on known response patterns and recovery times (Clarkson, 1997), the resolution was not fine enough to resolve the fast re-growth of many species to pre-fire conditions. As discussed, a finer resolution was not achievable due to the amount of material needed for accurate plant cuticle analysis and additional material required for bulk density and LOI analyses. In particular for fine-resolution fire studies, it is therefore important to weigh up the advantages and disadvantages of the chosen sampling resolution based on the peat accumulation rate. For example, peat accumulation rates at Kopouatai Bog in the Waikato Region are almost twice as fast as Moanatuatua Bog, which would provide a more accurate analysis of recovery times after fire events. Additionally, the presence of glass shards in samples of analysis F6A, in contrast with the lack thereof in the same section at coarse resolution, highlights the value of fine resolution sampling. It shows, how easy some indicators can be missed on coarse resolution, whereas a finer resolution would reveal more small changes.

In general, plant cuticles seemed to be preserved very well at Moanatuatua Bog and more than sufficient cuticles were available for extraction. In many cases, considerably more than 100 cuticles were mounted on microscope slides for further identification. However as discussed in Chapter 4.3, samples 1202R4B, 1202R5A and 1202R5B (at $370 \mathrm{~cm}, 419 \mathrm{~cm}$ and $469 \mathrm{~cm}$ depth, respectively) at coarse resolution contained small and very fragmented plant remains (Table 10) thus making the extraction of sufficient cuticles a longer process. A closer analysis revealed a correlation with bulk density and organic matter fluctuations in this time period (Fig. 27; Chapter 5.1.3). Additionally, sample 1202R4A is the only sample that contains glass shards between $124 \mathrm{~cm}$ and $669 \mathrm{~cm}$ depth. As Moanatuatua Bog was likely to be already developed as a raised bog (Chapter 5.1.1), airfall events such as dust or ash influx rather than input from groundwater must be the reason for the pronounced drops in the amount of organic matter. When compared with the pollen record, the same time period shows a peak in both restiad species, indicating wetter and warmer climatic conditions (pers. comm. Aline Homes, VUW). Wetter conditions however, suggest no reduction in preservation would have taken place. It 
is therefore suspected, that airfall events triggered the below-average preservation of plant cuticles.

Overall, plant cuticle analysis provides a successful method to differentiate between Empodisma and Sporadanthus cuticles and reconstruct local bog surface vegetation changes throughout the Holocene. In comparison with pollen analysis, sample preparation is fairly quick and no extensive equipment or chemicals are needed. Additionally, results can directly be enhanced by bulk density, LOI as well as further plant macrofossil analysis. With a detailed reference collection, identification of plant cuticles is easy to learn as features such as stomatal complexes are rather pronounced.

\section{$\underline{\text { Recommendations for further work }}$}

Further work should involve the extension of reference material as the amount of unidentifiable cuticles is still rather large. More analysis could also be done on the actual cuticles as cuticular analysis can provide palaeoclimatic information by analysing stomatal density (number of stomata per leaf area). Studies on modern plant leaves found that the number of stomata on the leaf surface is correlated with the atmospheric $\mathrm{CO}_{2}$ concentration. In general, the higher the $\mathrm{CO}_{2}$ concentration in the atmosphere, the higher the stomatal density. This relationship can be used to record changes in the $\mathrm{CO}_{2}$ concentration over geological timescales (Barclay et al., 2007; Pott \& Kerp, 2008). Additionally, the preservation potential of different plant species could be further investigated by comparing modern flora material with specimens from various deeper peat layers and noting differences in the appearance. As mentioned (Chapter 5.2), fire response studies could be conducted at faster accumulating sites to reconstruct changing response patterns and recovery times throughout the Holocene. Finer resolution studies could also help in better evaluating and analysing the relationship between climatic changes, the frequency and intensity of fires and the abundance of restiads on the bog surface. Also, identification of the four types of fruit categorised in this thesis would be suggested. 


\section{Conclusion}

This chapter synthesizes the main results of this study with regards to the aim and objectives set out in Chapter 1.2. The aim of this study was to test if subfossil plant cuticles can give a robust reconstruction of local bog surface vegetation changes during the Holocene. It was addressed through three main objectives:

The first objective involved the development of a new method to retrieve, identify and quantify subfossil plant cuticles from peat cores from Moanatuatua Bog. Based on established and well-accepted standardised tools for analysing plant remains from peat deposits, a new method was developed (Chapter 3.3.3). It combines a basic plant macrofossil analysis under the dissecting microscope with the extraction and further classification of $100+$ plant cuticles. The extracted plant cuticles are mounted on microscope slides and examined under the optical microscope for identification to species level.

The second objective aimed to apply the new method at coarse resolution, subsampling at regular intervals across the whole length of the sequence to reconstruct changes in the local vegetation assemblage during the Holocene. Analyses showed that subfossil plant cuticles, when compared to a pollen record from the same sequence, can give a reconstruction of the general vegetation changes during the Holocene at Moanatuatua Bog that conforms to the current understanding of peat ontogeny (Clarkson et al., 2004). The pollen record at Moanatuatua Bog fails to document an early sedge-dominated phase, whereas plant cuticles, which are recording local vegetation changes rather than regional ones, provide evidence for the dominance of sedges in the early stages of peat accumulation. At about $10500 \mathrm{cal}$ yr BP, the dominance of sedges began to wane, allowing the formation of a more diverse vegetation assemblage. Correlating with this transition, the amount of macroscopic charcoal particles notably increases. Both restiads, Empodisma and Sporadanthus subsequently become the dominant species on the bog.

The third objective aimed to apply the new method at fine resolution, sampling shortly before and after three key charcoal layers in the sequence to reconstruct 
changes in the vegetation assemblage in response to fire events on the bog surface. Two out of the three layers recorded a local fire as indicated by a peak in macroscopic charcoal. Furthermore, both showed vegetation responses that were expected when compared to an observed vegetation recovery process following fire at Moanatuatua Bog (Clarkson, 1997). Between the two restiad species, Empodisma re-establishes before Sporadanthus after a fire on the bog surface and overall sedges are the fastest species to re-establish. Due to the sampling resolution and the peat accumulation rate at Moanatuatua Bog, each sample was indicative of 20 years of peat accumulation, which complicated further comparisons.

As a summary, subfossil plant cuticles can give a robust reconstruction of local bog surface vegetation changes both at the long term geological and the short term ecological scale. The method provides a fast way of differentiating between restiads and reconstruct local bog surface vegetation changes at Moanatuatua Bog and similar bogs throughout the Holocene. Also, Moanatuatua Bog proved to be a good location to test subfossil plant cuticle analyses. As it developed in the Holocene, the assumption of methodological uniformitarianism is valid and applicable in the timeframe of this study. Furthermore due to it being a raised restiad bog, plant remains were mostly preserved very well in the record. Difficulties with the identification of restiad pollen and the fact that semi-quantitative quadrat and leafcount macrofossil analysis cannot be employed in its original form on these bogs, enables plant cuticle analysis to provide further information. 


\section{REFERENCES}

Agnew, A.; Rapson, G.; Sykes, M. \& Wilson, J. (1993): The functional ecology of Empodisma minus (Hook.J.), Johnson \& Cutler in New Zealand ombrotrophic mires. New Phytologist 124 (4): 703 - 710.

Anderson, D.; Goudie, A. \& Parker, A. (2013): Global Environments through the Quaternary: Exploring Environmental Change. Oxford: Oxford University Press.

Bannister, J.; Conran, J. \& Lee, D. (2012): Lauraceae from rainforest surrounding an early Miocene maar lake, Otago, southern New Zealand. Review of Palaeobotany and Palynology 178: 13 - 34.

Baranova, M. (1992): Principles of comparative stomatographic studies of flowering plants. Botanical Review 58: 49 - 99.

Barber, K. (1993): Peatlands as scientific archives of past biodiversity. Biodiversity and Conservation 2: 474 - 489.

Barber, K.; Chambers, F.; Maddy, D.; Stoneman, R. \& Brew, J. (1994): A sensitive high-resolution record of late Holocene climatic change from a raised bog in northern England. The Holocene 4 (2): 198 - 205.

Barber, K.; Chambers, F. \& Maddy, D. (2003): Holocene palaeoclimates from peat stratigraphy: macrofossil proxy climate records from three oceanic raised bogs in England and Ireland. Quaternary Science Reviews 22: 521 - 539.

Barber, K.; Chambers, F. \& Maddy, D. (2004): Late Holocene climatic history of northern Germany and Denmark: peat macrofossil investigations at Dosenmoor, Schleswig-Holstein, and Svanemose, Jutland. Boreas 33: 132 144. 
Barber, K. \& Charman, D. (2005): Holocene palaeoclimate records from peatlands. In: Mackay, A.; Battarbee, R.; Birks, J. \& Oldfield, F.: Global change in the Holocene. London: Hodder Arnold. pp. 210 - 226.

Barclay, G. (2002): Plant Anatomy. In: Encyclopedia of Life Sciences. Chichester: John Wiley \& Sons, Ltd.

Barclay, R.; McElwain, J.; Dilcher, D. \& Sageman, B. (2007): The cuticle database: Developing an interactive tool for taxonomic and palaeoenvironmental study of the fossil cuticle record. Courier Forschungsinstitut Senckenberg 258: 39 - 55.

Batzer, D. \& Sharitz, R. (2006): Ecology of freshwater and estuarine wetlands. Berkeley: University of California Press.

Belyea, L. (2009): Nonlinear dynamics of peatlands and potential feedbacks on the climate system. In: Baird, A.; Belyea, L.; Comas, X.; Reeve, A. \& Slater, L.: Carbon Cycling in Northern Peatlands. Washington: American Geophysical Union. pp. $5-18$.

Birks, H. (1981): The use of pollen anlysis in the reconstruction of past climates: a review. In: Wigley, T.; Ingram, M. \& Farmer, G.: Climate and History. Studies in past climates and their impact on man. Cambridge: Cambridge University Press. pp. $111-138$.

Birks, H. (2001): Plant macrofossils. In: Smol, J.; Birks, H. \& Last, W.: Tracking environmental change using lake sediments. Vol. 3. Terrestrial, algal, and siliceous indicators. Dordrecht: Kluwer Academic Publishers. pp. 49 - 74.

Birks, H. (2007): Plant macrofossil introduction. In: Scott, A.: Encylopedia of Quaternary Science. Elsevier. pp. 2266 - 2288.

Birks, H. \& Birks, H. (1980): Quaternary Palaeoecology. London: Edward Arnold. 
Birks, H. \& Birks, H. (2000): Future use of pollen analysis must include plant macrofossils. Journal of Biogeography 27 (1): 31 - 35.

Birks, H. \& Birks, H. (2005): Reconstructing Holocene climates from pollen and plant macrofossils. In: Mackay, A.; Battarbee, R.; Birks, J. \& Oldfield, F.: Global change in the Holocene. London: Hodder Arnold. pp. 342 - 357.

Blaauw, M. \& Christen, J.A. (2011): Flexible paleoclimate age-depth models using an autoregressive gamma process. Bayesian Analysis 6: 457 - 474.

Blackford, J. (1993): Peat bogs as sources of proxy climatic data: past approaches and future research. In: Chambers, F.: Climate Change and Human Impact on the Landscape. London: Chapman\&Hall. pp. $47-56$.

Blackford, J. (2000): Palaeoclimatic records from peat bogs. Trends in Ecology and Evolution 15: 193 - 198.

Blytt, A. (1876): Essay on the immigration of the Norwegian flora during alternating rainy and dry periods. Christiania: Cammermeyer.

Booth, R. \& Jackson, S. (2003): A high-resolution record of late-Holocene moisture variability from a Michigan raised bog, USA. The Holocene 13 (6): 865 878.

Bornemann, J. (1856): Über organische Reste der Lettenkohlengruppe Thüringens. Ein Beitrag zur Fauna und Flora dieser Formation, besonders über fossile Cycadeen, nebst vergleichenden Untersuchungen über Blattstruktur der jetztweltlichen Cycadeengattungen. Leipzig: Verlag von Wilhelm Engelmann.

Campbell, E. (1964): The restiad peat bogs at Motumaoho and Moanatuatua. Transactions of the Royal Society of New Zealand. Botany 2 (16): 219 - 227. 
Campbell, E. (1975): Peat deposits of northern New Zealand as based on identification of plant fragments in the peat. Proceedings of the New Zealand ecological society 22: $57-60$.

Campbell, E.; Heine, J. \& Pullar, W. (1973): Identification of plant fragments and pollen from peat deposits in Rangitaiki Plains and Maketu Basins. New Zealand Journal of Botany 11: 317 - 330.

Campbell, D. \& Williamson, J. (1997): Evaporation from a raised peat bog. Journal of Hydrology 193: 142 - 160.

Campbell, D.; Smith, J.; Goodrich, J.; Wall, A. \& Schipper, L. (2014): Yearround growing conditions explains large $\mathrm{CO} 2$ sink strength in a New Zealand raised peat bog. Agricultural and Forest Meteorology 192/193: 59 - 68.

Chambers, F. \& Charman, D. (2004): Holocene environmental change: contributions from the peatland archive. The Holocene 14 (1): 1 - 6.

Chambers, F.; Beilman, D. \& Yu, Z. (2011): Methods for determining peat humification and for quantifying peat bulk density, organic matter and carbon content for palaeostudies of climate and peatland carbon dynamics. Mires and Peat 7 (07): 1 - 10.

Chambers, F.; Booth, R.; De Vleeschouwer, F.; Lamentowicz, M.; Le Roux, G.; Mauquoy, D.; Nichols, J.E. \& van Geel, B. (2012): Development and Refinement of proxy-climate indicators from peats. Quaternary International 268: $21-33$.

Charman, D.J.; Barber, K.E.; Blaauw, M.; Langdon, P.G.; Mauquoy, D.; Daley, T.J.; Hughes, P.D.M. \& Karofeld, E. (2009): Climate drivers for peatland palaeoclimate records. Quaternary Science Review 28: 1811 - 1819.

Chiverell, R. (2001): A proxy record of late Holocene climate change from May Moss, northeast England. Journal of Quaternary Science 16 (1): 9 - 29. 
Clarke, C. (2013): Palaeoecological Reconstructions. In: Menotti, F. \& O'Sullivan,

A.: The Oxford Handbook of Wetland Archaeology. Oxford: Oxford University Press. pp. $539-554$.

Clarkson, B. (1997): Vegetation recovery following fire in two Waikato peatlands at Whangamarino and Moanatuatua, New Zealand. New Zealand Journal of Botany 35: 167 - 179.

Clarkson, B. (2002): Swamps, fens and bogs. In: Clarkson, B.; Merrett, M. \& Downs, T.: Botany of the Waikato. Hamilton: Waikato Botanical Society. pp. $49-58$.

Clarkson, B.; Thompson, K.; Schipper, L. \& McLeod, M. (1999): Moanatuatua Bog - Proposed Restoration of a New Zealand Restiad Peat Bog Ecosystem. In: Streever, W.: An International Perspective on Wetland Rehabilitiation. Springer. pp. $127-137$.

Clarkson, B.; Schipper, L. \& Lehmann, A. (2004): Vegetation and peat characteristics in the development of lowland restiad peat bogs, North Island, New Zealand. Wetlands 24 (1): 133 - 151.

Clarkson, B.; Clarkson, B. \& Downs, T. (2007): Indigenous vegetation types of Hamilton Ecological District. CBER Contract Report 58. Hamilton: University of Waikato.

de Lange, P. (1989): Late Quaternary development of the Kopouatai Peat bog, Hauraki lowlands and some palaeoenvironmental inferences. Unpublished MSc thesis. Hamilton: University of Waikato.

de Lange, P.; Heenan, P.; Clarkson, B. \& Clarkson, B. (1999): Taxonomy, ecology, and conservation of Sporadanthus (Restionaceae) in New Zealand. New Zealand Journal of Botany 37: 413 - 431. 
Dean, W. (1974): Determination of carbonate and organic matter in calcareous sediments and sedimentary rocks by loss on ignition: comparison with other methods. Journal of sedimentary petrology 44 (1): 242 - 248.

Dilcher, D. (1974): Approaches to the identification of Angiosperm leaf remains. Botanical Review 40 (1): 1 - 157.

Evert, R. (2006): Esau's Plant Anatomy. Meristems, cells, and tissues of the plant body - Their structure, function, and development. Hoboken: John Wiley \& Sons, Inc.

Fletcher, M.-S.; Wood, S. \& Haberle, S.G. (2014): A fire-driven shift from forest to non-forest: evidence for alternative stable states?. Ecology 95 (9): 2504 2513.

Florin, R. (1931): Untersuchungen zur Stammesgeschichte der Coniferales und Cordaitales. K. Svensk. Vetenskaps. Handl. III 10 (1): 1 - 588.

Florin, R. (1933): Studien über die Cycaidales des Mesozoikums. Erörterung über die Spaltöffnungsapparate der Bennettitales. K. Svensk. Vetenskaps. Handl. III 12 (5): 1 - 134.

Gehrels, M. (2009): An enhanced $\sim 1800$ year record of recent volcanic ash-fall events for northern New Zealand from the analysis of cryptotephra. Unpublished PhD thesis. Plymouth, UK: University of Plymouth.

Green, J. \& Lowe, D. (1985): Stratigraphy and development of c. 17000 year old Lake Maratoto, North Island, New Zealand, with some inferences about postglacial climatic change. New Zealand Journal of Geology and Geophysics 28: 675 - 699.

Grimm, E. (2011): Tilia, version 1.7.16. Illinois State Museum, Research and Collection Center. Springfield, USA. 
Grosse-Brauckmann, G. (1986): Analyis of vegetative plant macrofossils. In:

Berglund, B. \& Ralska-Jasiewiczowa, M.: Handbook of Holocene palaeoecology and palaeohydrology. Chichester: John Wiley\&Sons Ltd. pp. $591-618$.

Hansson, S.; Rydberg, J.; Kylander, M.; Gallagher, K. \& Bindler, R. (2013):

Evaluating paleproxies for peat decomposition and their relationship to peat geochemistry. The Holocene 23 (12): 1666 - 1671.

Hazell, Z. (2004): Holocene palaeoclimate reconstruction from New Zealand peatlands. Unpublished $\mathrm{PhD}$ thesis. Hamilton, Plymouth: University of Plymouth, University of Waikato.

Heiri, O.; Lotter, A. \& Lemcke, G. (2001): Loss on ignition as a method for estimating organic and carbonate content in sediments: reproducibility and comparibility of results. Journal of Paleolimnology 25: 101 - 110.

Hogg, A.G.; Lowe, D.J.; Hendy, C.H. (1987): University of Waikato radiocarbon dates I. Radiocarbon 29: 263 - 301.

Jakab, G.; Sümegi, P. \& Magyari, E. (2004): A new palaeobotanical method for the description of Late Quaternary organic sediments (Mire-development pathways and palaeoclimatic records from S-Hungary). Acta Geologica Hungarica 47 (4): 1 - 37.

Johnson, P. (2001): Vegetation recovery after fire on a southern New Zealand peatland. New Zealand Journal of Botany 39 (2): 251 - 267.

Johnson, P. \& Gerbeaux, P. (2004): Wetland Types in New Zealand. Wellington: Department of Conservation.

Kerp, H. (1990): The study of fossil gymnosperms by means of cuticular analysis. PALAIOS 5 (6): 548 - 569. 
Kerp, H. \& Krings, M. (1999): Light microscopy of cuticles. In: Jones, T. \& Rowe, N.: Fossil plants and spores: modern techniques. London: Geological Society. pp. $52-56$.

Kerstiens, G. (2010): Plant cuticle. In: Encyclopedia of Life Sciences. Chichester: John Wiley\&Sons, Ltd.

Langdon, P.; Barber, K. \& Hughes, P. (2003): A 7500-year peat-based palaeoclimatic reconstruction and evidence for an 1100-year cyclicity in bog surface wetness from Temple Hill Moss, Pentland Hills, southeast Scotland. Quaternary Science Reviews 22: 259 - 274.

Lee, D.; Conran, J.; Lindquist, J.; Bannister, J. \& Mildenhall, D. (2012): New Zealand Eocene, Oligocene and Miocene Macrofossil and Pollen Records and Modern Plant Distributions in the Southern Hemisphere. The Botanical Review 78: 235 - 260.

Li, Y.-C.; Xu, Q.-H.; Yang, X.-L.; Chen, H. \& Lu, X.-M. (2005): Pollen vegetation relationship and pollen preservation on the Northeastern QuinghaiTibetan Plateau. Grana 44 (3): 160 - 171.

Lowe, D.J. (1988): Stratigraphy, age, composition, and correlation of late Quaternary tephras interbedded with organic sediments in Waikato lakes, North Island, New Zealand. New Zealand Journal of Geology and Geophysics 31: $125-165$.

Lowe, D. (2010): Introduction to the landscapes and soils of the Hamilton Basin. In: Lowe, D.; Neall, V.; Hedley, M.; Clothier, B. \& Mackay, A.: Guidebook for Pre-Conference North Island, New Zealand 'Volcanoes to Oceans' field tour (27-30 July). Soil and Earth Sciences Occasional Publication No. 3. 19th World Soils Congress, International Union of Soil Sciences, Brisbane. Massey University, Palmerston North. pp. $1.24-1.61$. 
Mannion, A. (1986): Plant macrofossils and their significance in Quaternary palaeoecology: Part 1: Introduction. Progress in Physical Geography 10: 194 $-214$.

Manville, V. \& Wilson, C. (2004): The 26.5ka Oruanui eruption, New Zealand: a review of the roles of volcanism and climate in the post-eruptive sedimentary response. New Zealand Journal of Geology \& Geophyiscs 47 (3): 525 - 547.

Mark, A. \& Smith, P. (1975): A lowland vegetation sequence in South Westland: Pakihi Bog to mixed beech: podocarp forest. Part 1: The principal strata. Proceedings of the New Zealand Ecological Society 22: 76 - 92.

Mauquoy, D. \& Barber, K. (1999): A replicated 3000yr proxy-climate record from Coom Rigg Moss and Felecia Moss, the Border Mires, northern England. Journal of Quaternary Science 14 (3): 263 - 275.

Mauquoy, D. \& Yeloff, D. (2008): Raised peat bog development and possible responses to environmental changes during the mid-to late-Holocene. Can the paleoecological record be used to predict the nature and response of raised peat bogs to future climate change? Biodiversity and Conservation 17 (9): $2139-2151$.

Mauquoy, D.; Hughes, P. \& van Geel, B. (2011): A protocol for plant macrofossil analysis of peat deposits. Mires and Peat 7 (6): 1 - 5.

McCraw. (2002): Phyiscal Environment. In: Clarkson, B.; Merrett, M. \& Downs, T.: Botany of the Waikato. Hamilton: Waikato Botanical Society. pp. $13-22$.

McGlone,M. (2009): Postglacial history of New Zealand wetlands and implications for their conservation. New Zealand Journal of Ecology 33 (1): 1 - 23. 
McGlone, M.; Nelson, C. \& Todd, A. (1984): Vegetation history and environmental significance of pre-peat and surficial peat deposits at Ohinewai, Lower Waikato lowland. Journal of the Royal Society of New Zealand 14 (3): 233 244.

McQueen, D.R. \& Macphail, M.K. (1983): The value of New Zealand pollen and spores as indicators of cenozoic vegetation and climates. Tuatara 26 (2): 37 56.

McQueen, J. \& Forester, L. (2000): Succession in the Kaimaumau gumland, Northland, New Zealand, following fire. Wellington: Department of Conservation.

Metcalfe, C. \& Chalk, L. (1950): Anatomy of the dictoyledons. Oxford: Clarendon Press.

Mooney, D. \& Tinner, W. (2011): The analysis of charcoal in peat and organic sediments. Mires and Peat 7 (9): 1 - 18.

Mooney, S.; Harrison, S.; Bartlein, P.; Daniau, A.-L.; Stevenson, J.; Brownlie, K. C.; Buckman, S.; Cupper, M.; Luly, J.; Black, M.; Colhoun, E.; D’Costa, D.; Dodson, J.; Haberle, S.; Hope, G. S.; Kershaw, P.; Kenyon, C.; McKenzie, M. \& Williams, N. (2011): Late Quaternary fire regimes of Australasia. Quaternary Science Reviews 30: 28 - 46.

Moore, T. \& Shearer, J. (2003): Peat/coal type and depositional environment - are they related? International Journal of Coal Geology 56: 233 - 252.

Newnham, R.; de Lange, P. \& Lowe, D. (1995): Holocene vegetation, climate and history of a raised bog complex, northern New Zealand based on palynology, plant macrofossils and tephrochronology. The Holocene 5 (3): 267 - 282. 
Norton, D. \& de Lange, P. (2003): Fire and vegetation in a temperate peat bog: implications for the management of threatened species. Conservation Biology 17 (1): $138-148$.

Perry, G.; Wilmshurst, J. \& McGlone, M. (2014): Ecology and long-term history of fire in New Zealand. New Zealand Journal of Ecology 38 (2): 157 - 176.

Pole, M. (2007a): Monocot Macrofossils from the Miocene of southern New Zealand. Palaeontologia Electronica 10 (3): 15 A.

Pole, M. (2007b): Lauraceae Macrofossils and Dispersed Cuticle from the Miocene of Southern New Zealand. Palaeontologia Electronica 10 (1): 3A.

Pole, M. (2007c): Early Eocene Dispersed Cuticles and Mangrove to Rainforest Vegetation at Strahan-Regatta Point, Tasmania. Palaeontologia Electronica 10 (3): $15 \mathrm{~A}$.

Pole, M.; Dawson, J. \& Denton, T. (2008): Fossil Myrtaceae from the early Miocene of Southern New Zealand. Australian Journal of Botany 56: 67 - 81.

Pole, M. \& Vajda, V. (2009): A new terrestrial Cretaceous-Paleogene site in New Zealand - turnover in macroflora confirmed by palynology. Cretaceous Research 30: 917 - 938.

Pott, C. \& Kerp, H. (2008): Mikroskopische Untersuchungsmethoden an fossilen Pflanzenabdruecken. Der Präparator 54: 50 - 61.

Rydin, H. \& Jeglum, J. (2006): The Biology of Peatlands. New York: Oxford University Press.

Scott, A. \& Jones, T. (1991): Fossil charcoal. A plant-fossil record preserved by fire. Geology today 7 (6): 214 - 216. 
Selby, M. \& Lowe, D. (1992): The middle Waikato Basin and Hills. In: Soons, J. \& Selby, M.: Landforms of New Zealand. Auckland: Longman Paul. pp. 233 255.

Sernander, R. (1908): On the evidence of post-glacial changes of climate furnished by peat mosses of northern Europe. Geologiska Föreningens i Stockholm Förhandlinger 30: $465-478$.

Sharitz, R. \& Pennings, S. (2006): Development of Wetland Plant Communities. In: Batzer, D. \& Sharitz, R.: Ecology of Freswater and Estuarine Wetlands. Berkeley: University of California Press. pp. 177 - 241.

Shearer, J. (1997): Natural and anthropogenic influences on peat development in Waikato/Hauraki Plains restiad bogs. Journal of the Royal Society of New Zealand 27 (3): 295 - 313.

Stanway, E.A. \& Clarkson, B.R. (1994): Vegetation Recovery following fire in the Whangamarino Wetland. Science \& Research Series 73. Wellington: Department of Conservation.

Taylor, T. (1999): The ultrastructure of fossil cuticle. In: Jones, T. \& Rowe, N.: Fossil plants and spores: modern techniques. London: Geological Society. pp. $113-115$.

Taylor, T.; Taylor, E. \& Krings, M. (2009): Paleobotany. The Biology and Evolution of Fossil Plants. Oxford: Academic Press.

Thompson, M.; Campbell, D. \& Spronken-Smith, R. (1999): Evaporation from natural and modified raised peat bogs in New Zealand. Agricultural and Forest Meteorology 95: 85 - 98.

Timmins, S. (1992): Wetland vegetation recovery after fire: Eweburn Bog, Te Anau, New Zealand. New Zealand Journal of Botany 30 (4): 383 - 399. 
van der Linden, M. \& van Geel, B. (2006): Late Holocene climate change and human impact recorded in a South Swedish ombrotrophic peat bog. Palaeogeography, Palaeoclimatology, Palaeoecology 240: 649 - 667.

Vesque, M. (1889): De l'emploi des caracteres anatomiques dans la classification des vegetaux. Bull. Soc. Bot. France 36: XLI - LXXVII.

Vuorela, I. (1973): Relative pollen rain around cultivated fields. Acta Botanica Fennica 102.

Wagstaff, S. \& Clarkson, B. (2012): Systematics and ecology of the Australasian genus Empodisma (Restionaceae) and description of a new species from peatlands in northern New Zealand. PhytoKeys 13: 39 - 79.

Walker, S.; Steel, J.; Rapson, G.; Roxburgh, S.; King, W.; Watkins, A.; Myers, T.E.; Keogh, J.A.; McQueen, A.A.M. \& Wilson, J.B. (2001): A Chinochloa/Sphagnum/Cushion Valley bog in east Otago, New Zealand. New Zealand Journal of Ecology 25 (1): 39 - 52.

Warner, B. (1988): Methods in Quaternary Ecology \#3. Plant macrofossils. Geoscience Canada 15 (2): 121 - 129.

Wessel, P. \& Weber, O. (1855): Neuer Beitrag zur Tertiärflora der niederrheinischen Braunkohlenformation. Palaeontographica 4: 111 - 178.

Wooler, M. (2002): Fossil grass cuticles from lacustrine sediments: a review of methods applicable to the analysis of tropical African lake cores. The Holocene 12 (1): 97 - 105.

Yeats, T. \& Rose, J. (2013): The formation and function of plant cuticles. Plant Physiology 163: 5 - 20. 


\section{APPENDICES}




\section{Cuticle identification}

\subsection{Stomatal complex types}

(compiled from Baranova, 1992; Barclay et al., 2007; Dilcher, 1974; Evert, 2006)

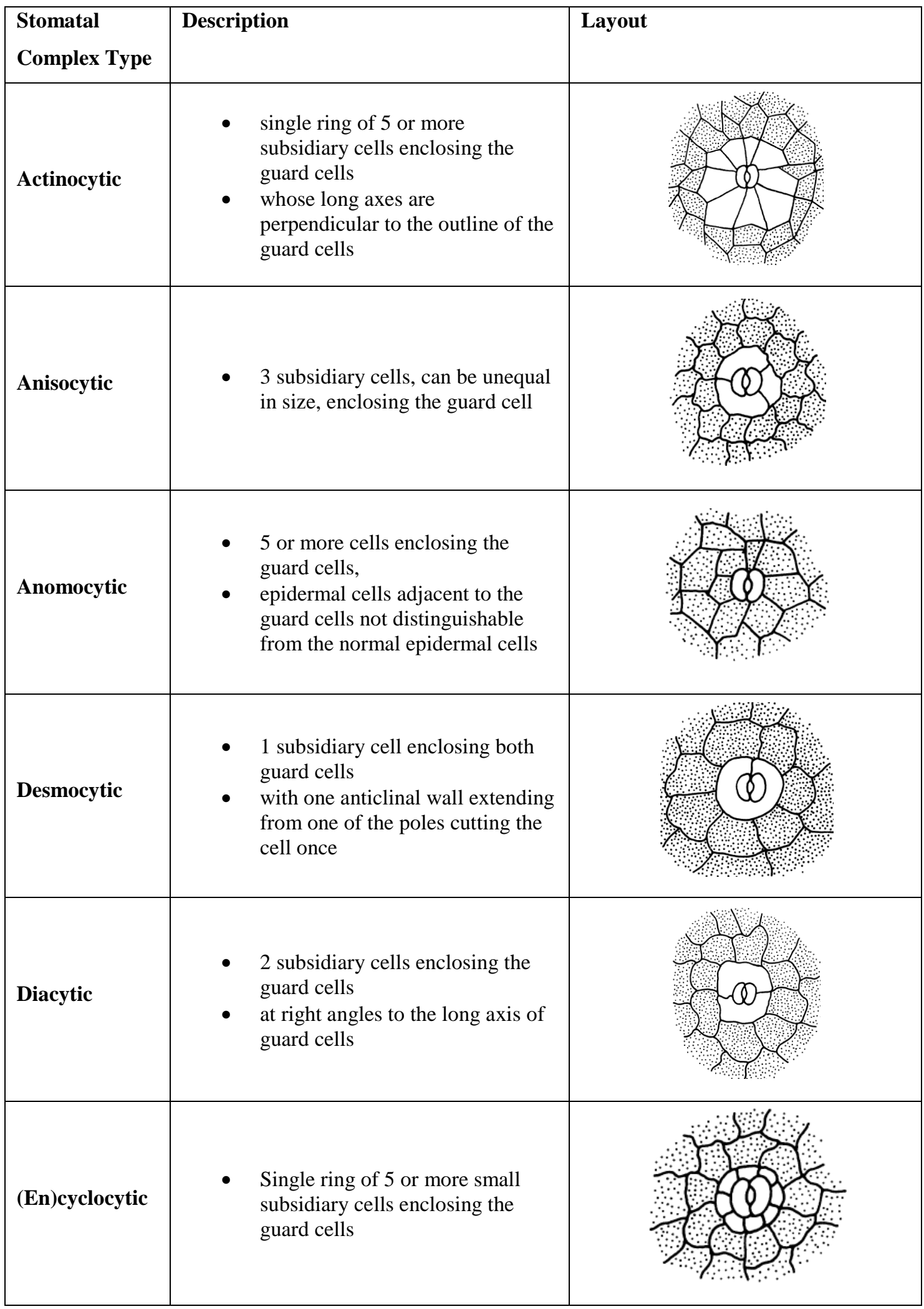




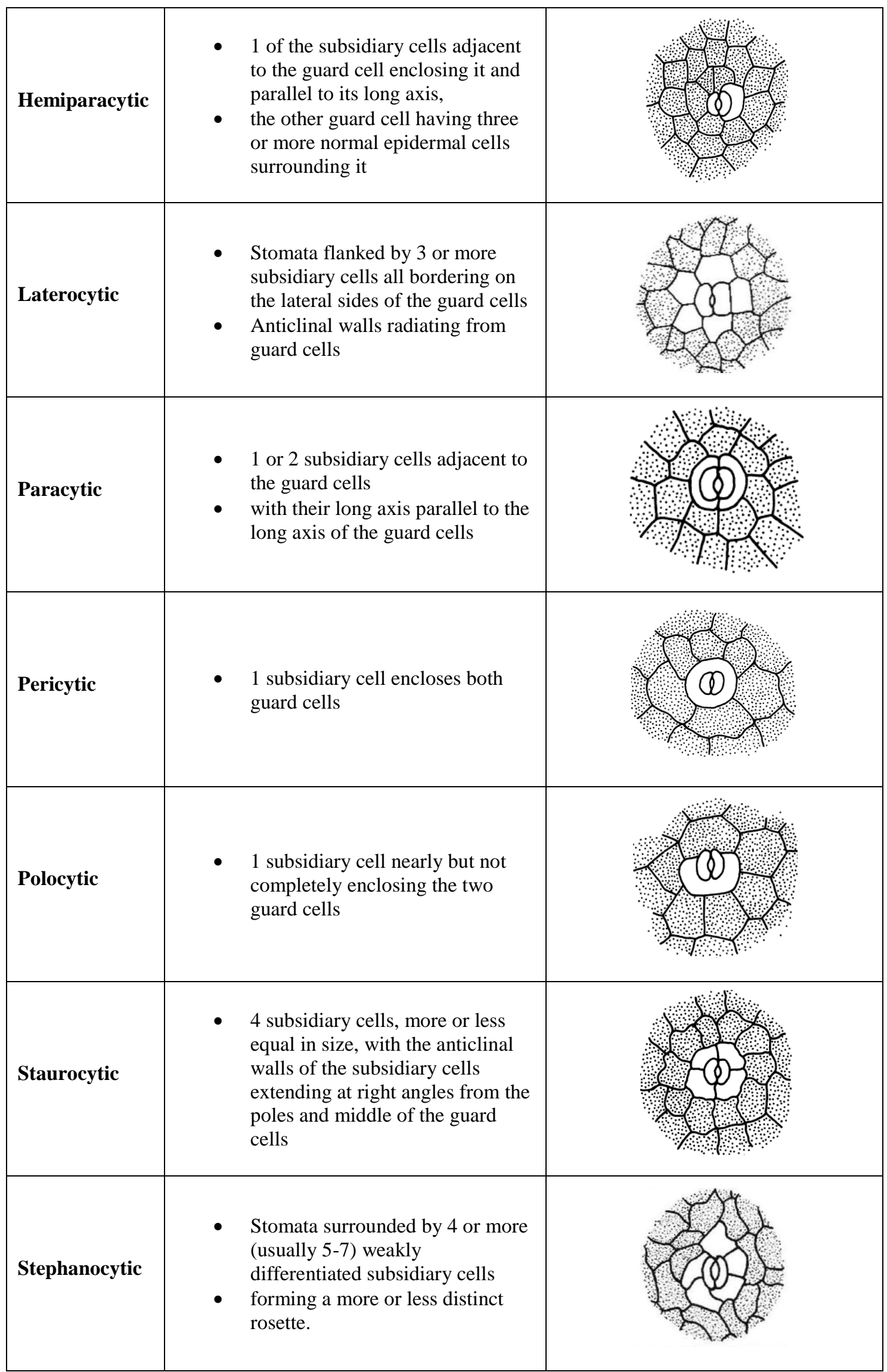




\begin{tabular}{|l|ll|}
\hline Tetracytic & - 4 subsidiary cells adjacent to and \\
enclosing the guard cell \\
Two lateral and two polar
\end{tabular}


1.2 Terminology for epidermal cell patterns in plant cuticle analysis (compiled from Dilcher, 1974)

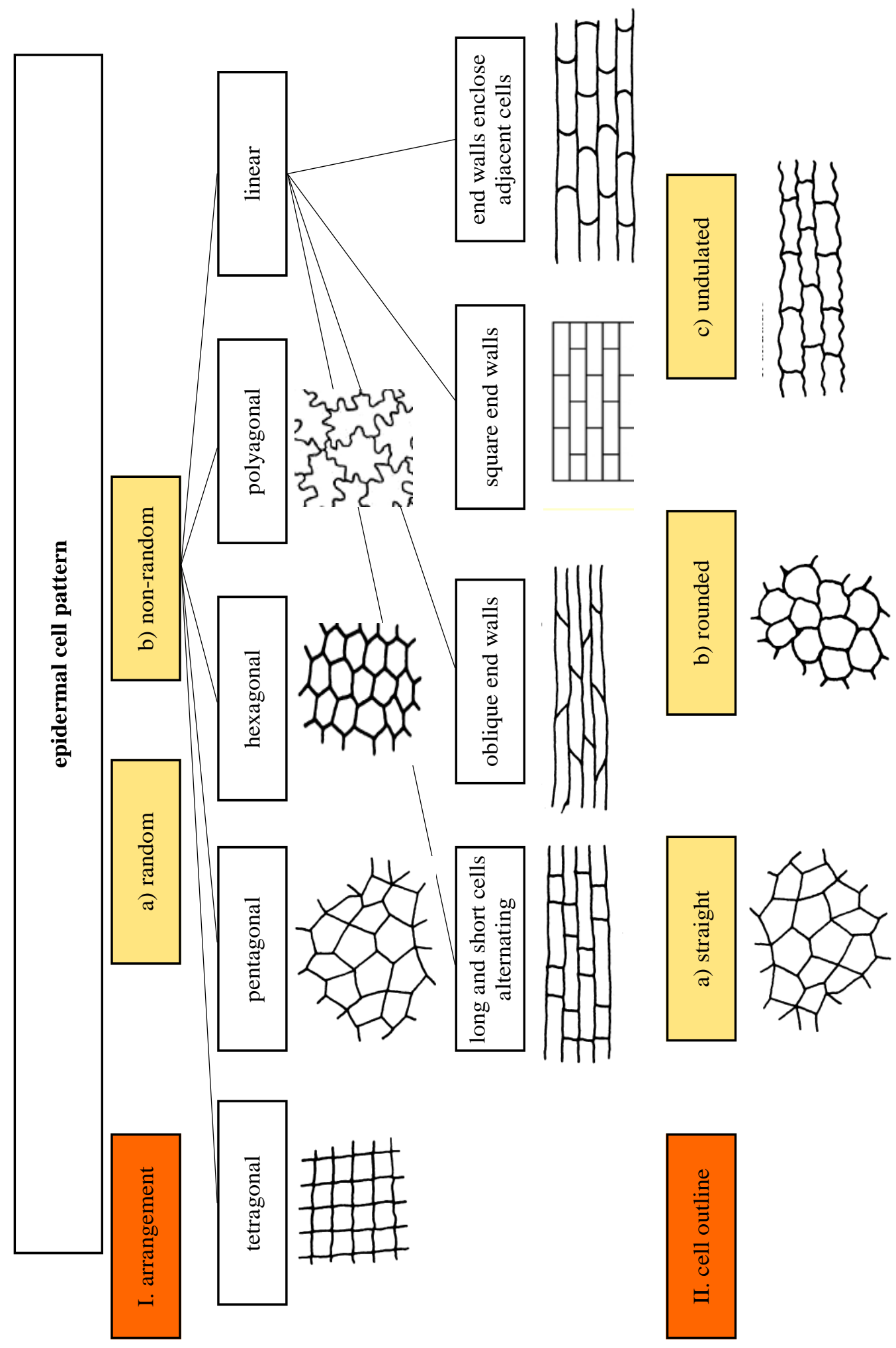




\section{1 raw plant cuticle and plant macrofossil data}

\begin{tabular}{|c|c|c|c|c|c|c|c|c|c|}
\hline & $\begin{array}{l}1202 \\
\text { R1A }\end{array}$ & $\begin{array}{l}1202 \\
\text { R1B }\end{array}$ & $\begin{array}{l}1202 \\
\text { R2A }\end{array}$ & $\begin{array}{l}1202 \\
\text { R2B }\end{array}$ & $\begin{array}{l}1202 \\
\text { R3A }\end{array}$ & $\begin{array}{l}1202 \\
\text { R3B }\end{array}$ & $\begin{array}{l}1202 \\
\text { R4A }\end{array}$ & $\begin{array}{l}1202 \\
\text { R4B }\end{array}$ & $\begin{array}{l}1202 \\
\text { R5A }\end{array}$ \\
\hline $\begin{array}{l}\text { sampling } \\
\text { interval }(\mathbf{c m})\end{array}$ & $26-28$ & $\begin{array}{l}24- \\
26\end{array}$ & $24-26$ & $23-25$ & $24-26$ & $23-25$ & $24-26$ & $24-26$ & $24-26$ \\
\hline weight $(\mathrm{g})$ & 2.504 & 2.52 & 2.506 & 2.512 & 2.514 & 2.53 & 2.597 & 2.482 & 2.515 \\
\hline depth $(\mathrm{cm})$ & 27 & 75 & 124 & 173 & 222 & 271 & 321 & 370 & 419 \\
\hline $\begin{array}{l}\text { age (cal yr } \\
\text { BP) }\end{array}$ & 294 & 1306 & 2344 & 3385 & 4390 & 5396 & 6429 & 7441 & 8432 \\
\hline cuticles (total) & 133 & 114 & 126 & 118 & 126 & 164 & 123 & 115 & 134 \\
\hline $\begin{array}{l}\text { Empodisma } \\
\text { cuticles }\end{array}$ & 35 & 2 & 35 & 15 & 1 & 23 & 18 & 7 & 14 \\
\hline $\begin{array}{l}\text { Sporadanthus } \\
\text { cuticles }\end{array}$ & 10 & 12 & 25 & 61 & 8 & 5 & 43 & & 1 \\
\hline $\begin{array}{l}\text { Gleichenia } \\
\text { cuticles }\end{array}$ & 15 & 2 & & & 3 & 8 & 2 & & 8 \\
\hline $\begin{array}{l}\text { monocot } \\
\text { cuticles }\end{array}$ & 7 & 4 & 2 & 4 & $\overline{53}$ & 35 & & 4 & 15 \\
\hline $\begin{array}{l}\text { sedge } \\
\text { cuticles }\end{array}$ & & & 1 & 3 & & 23 & 10 & 4 & 8 \\
\hline $\begin{array}{l}\text { Leptospermum } \\
\text { cuticles }\end{array}$ & 9 & 1 & 17 & 3 & 3 & 1 & 13 & 25 & \\
\hline $\begin{array}{l}\text { others } \\
\text { cuticles }\end{array}$ & 57 & 93 & 46 & 32 & 58 & 69 & 37 & 75 & 88 \\
\hline $\begin{array}{l}\text { macroscopic } \\
\text { charcoal }\end{array}$ & 488 & 161 & 683 & 870 & 57 & 440 & 746 & 347 & 1250 \\
\hline $\begin{array}{l}\text { fern } \\
\text { sporangia }\end{array}$ & & 21 & 19 & 66 & 4 & 6 & 32 & & 2 \\
\hline \multicolumn{10}{|l|}{ root nodules } \\
\hline $\begin{array}{l}\text { Fruit\&Seed, } \\
\text { Type } 1\end{array}$ & & 4 & & 1 & 13 & 1 & 6 & & 4 \\
\hline $\begin{array}{l}\text { Fruit\&Seed, } \\
\text { Type } 2\end{array}$ & 8 & 9 & & 5 & 2 & 5 & 13 & 4 & 1 \\
\hline $\begin{array}{l}\text { Fruit\&Seed, } \\
\text { Type } 3\end{array}$ & & 1 & & & 5 & 10 & 9 & & \\
\hline $\begin{array}{l}\text { Fruit\&Seed, } \\
\text { Type } 4\end{array}$ & & & & & & & & & \\
\hline
\end{tabular}




\begin{tabular}{|c|c|c|c|c|c|c|c|c|}
\hline $\begin{array}{l}1202 \\
\text { R5B }\end{array}$ & $\begin{array}{l}1202 \\
\text { R6A }\end{array}$ & $\begin{array}{l}1202 \\
\text { R6B }\end{array}$ & $\begin{array}{l}1202 \\
\text { R7A }\end{array}$ & $\begin{array}{l}1202 \\
\text { R7B }\end{array}$ & $\begin{array}{l}1201 \\
\text { R7B }\end{array}$ & $\begin{array}{l}1201 \\
\text { R8A }\end{array}$ & $\begin{array}{l}1201 \\
\text { R8A }\end{array}$ & \\
\hline $24-26$ & $24-26$ & $24-26$ & $24-26$ & $24-26$ & $22-25$ & $0.8-10$ & $24-26$ & $\begin{array}{l}\text { sampling } \\
\text { interval }(\mathbf{c m})\end{array}$ \\
\hline 2.5 & 2.508 & 2.55 & 2.51 & 2.508 & 5.505 & 2.552 & 2.524 & weight (g) \\
\hline 469 & 519 & 569 & 619 & 669 & 692 & 710 & 730 & depth (cm) \\
\hline 9455 & 10477 & 11698 & 12811 & 13690 & 14086 & 14371 & 14676 & $\begin{array}{l}\text { age (cal yr } \\
\text { BP) }\end{array}$ \\
\hline \multirow[t]{2}{*}{108} & 110 & 101 & 114 & 107 & 69 & & & cuticles (total) \\
\hline & 1 & & & & & & & $\begin{array}{l}\text { Empodisma } \\
\text { cuticles }\end{array}$ \\
\hline \multirow[t]{2}{*}{25} & & & & & & & & $\begin{array}{l}\text { Sporadanthus } \\
\text { cuticles }\end{array}$ \\
\hline & & & & & & & & $\begin{array}{l}\text { Gleichenia } \\
\text { cuticles }\end{array}$ \\
\hline 8 & 4 & 6 & 6 & 8 & & & & $\begin{array}{l}\text { monocot } \\
\text { cuticles }\end{array}$ \\
\hline \multirow[t]{2}{*}{31} & 62 & 41 & 71 & 31 & 12 & & & $\begin{array}{l}\text { sedge } \\
\text { cuticles }\end{array}$ \\
\hline & & & & & & & & $\begin{array}{l}\text { Leptospermum } \\
\text { cuticles }\end{array}$ \\
\hline 44 & 43 & 54 & 37 & 68 & 57 & & & $\begin{array}{l}\begin{array}{l}\text { others } \\
\text { cuticles }\end{array} \\
\text { lo }\end{array}$ \\
\hline 1729 & 193 & 253 & 65 & 230 & 55 & 6 & & $\begin{array}{l}\text { macroscopic } \\
\text { charcoal }\end{array}$ \\
\hline \multirow[t]{2}{*}{1} & 2 & 2 & 13 & 39 & & & & $\begin{array}{l}\text { fern } \\
\text { sporangia }\end{array}$ \\
\hline & & & & & 328 & 24 & & root nodules \\
\hline 2 & & & & & & & & $\begin{array}{l}\text { Fruit\&Seed, } \\
\text { Type } 1\end{array}$ \\
\hline \multirow[t]{2}{*}{$\overline{18}$} & & 3 & & 2 & & & & $\begin{array}{l}\text { Fruit\&Seed, } \\
\text { Type } 2\end{array}$ \\
\hline & & & & 1 & & & & $\begin{array}{l}\text { Fruit\&Seed, } \\
\text { Type } 3\end{array}$ \\
\hline 1 & 5 & 4 & $\overline{6}$ & 27 & 21 & & & $\begin{array}{l}\text { Fruit\&Seed, } \\
\text { Type } 4\end{array}$ \\
\hline
\end{tabular}




\section{2 raw bulk density and organic matter data}

\begin{tabular}{|l|l|l|l|l|l|}
\hline $\begin{array}{l}\text { Depth } \\
(\mathbf{c m})\end{array}$ & $\begin{array}{l}\text { Bulk } \\
\text { density } \\
\left(\mathbf{g} / \mathbf{c m}^{\mathbf{3}}\right)\end{array}$ & $\begin{array}{l}\text { Organic } \\
\text { matter } \\
(\mathbf{\%})\end{array}$ & $\begin{array}{l}\text { Depth } \\
(\mathbf{c m})\end{array}$ & $\begin{array}{l}\text { Bulk } \\
\text { density } \\
\left(\mathbf{g} / \mathbf{c m}^{\mathbf{3}}\right)\end{array}$ & $\begin{array}{l}\text { Organic } \\
\text { matter } \\
(\mathbf{\%})\end{array}$ \\
\hline $\mathbf{2}$ & 0.113 & 97.943 & $\mathbf{4 1 9}$ & 0.094 & 92.072 \\
\hline $\mathbf{2 7}$ & 0.104 & 98.620 & $\mathbf{4 4 2}$ & 0.190 & 51.771 \\
\hline $\mathbf{4 9}$ & 0.355 & 98.941 & $\mathbf{4 6 9}$ & 0.110 & 91.661 \\
\hline $\mathbf{7 5}$ & 0.143 & 65.376 & $\mathbf{4 9 2}$ & 0.104 & 81.399 \\
\hline $\mathbf{9 8}$ & 0.089 & 96.850 & $\mathbf{5 1 9}$ & 0.111 & 92.486 \\
\hline $\mathbf{1 2 4}$ & 0.124 & 70.524 & $\mathbf{5 4 1}$ & 0.112 & 86.981 \\
\hline $\mathbf{1 4 6}$ & 0.138 & 97.448 & $\mathbf{5 6 9}$ & 0.110 & 91.890 \\
\hline $\mathbf{1 7 3}$ & 0.124 & 90.544 & $\mathbf{5 9 1}$ & 0.135 & 74.926 \\
\hline $\mathbf{1 7 3}$ & 0.106 & 70.228 & $\mathbf{6 1 9}$ & 0.124 & 89.076 \\
\hline $\mathbf{1 7 3}$ & 0.110 & 74.818 & $\mathbf{6 4 3}$ & 0.159 & 54.600 \\
\hline $\mathbf{1 9 5}$ & 0.087 & 95.596 & $\mathbf{6 4 3}$ & 0.164 & 57.490 \\
\hline $\mathbf{2 2 2}$ & 0.095 & 98.820 & $\mathbf{6 4 3}$ & 0.153 & 66.527 \\
\hline $\mathbf{2 4 5}$ & 0.113 & 98.025 & $\mathbf{6 6 9}$ & 0.138 & 63.552 \\
\hline $\mathbf{2 7 1}$ & 0.099 & 98.058 & $\mathbf{6 7 6}$ & 0.862 & 12.727 \\
\hline $\mathbf{2 8 9}$ & 0.087 & 97.711 & $\mathbf{6 8 0}$ & 0.128 & 83.875 \\
\hline $\mathbf{3 2 1}$ & 0.088 & 97.721 & $\mathbf{6 9 2}$ & 0.173 & 83.441 \\
\hline $\mathbf{3 4 4}$ & 0.075 & 97.112 & $\mathbf{7 1 5}$ & 0.289 & 37.344 \\
\hline $\mathbf{3 7 0}$ & 0.120 & 74.047 & $\mathbf{7 2 0}$ & 0.368 & 33.536 \\
\hline 393 & 0.168 & 54.346 & $\mathbf{7 5 0}$ & 0.654 & 12.913 \\
\hline
\end{tabular}


3 Results at fine resolution 


\section{1 raw plant cuticle and plant macrofossil data}

\begin{tabular}{|c|c|c|c|c|c|c|c|c|}
\hline & F3B -4 & F3B -3 & F3B -2 & F3B -1 & F3B 0A & F3B 0B & F3B +1 & F3B +2 \\
\hline $\begin{array}{l}\text { sampling } \\
\text { interval }(\mathrm{cm})\end{array}$ & $34-35$ & $35-36$ & $36-37$ & $37-38$ & $38-39$ & $39-40$ & $40-41$ & $41-42$ \\
\hline weight (g) & 2.05 & 2.01 & 2.04 & 2.03 & 2.02 & 2.04 & 2.02 & 2.04 \\
\hline depth $(\mathrm{cm})$ & 282 & 283 & 284 & 285 & 286 & 287 & 288 & 289 \\
\hline age (cal yr BP) & 5621 & 5642 & 5663 & 5683 & 5704 & 5725 & 5746 & 5768 \\
\hline cuticles (total) & 111 & 108 & 130 & 129 & 121 & 100 & 150 & 119 \\
\hline $\begin{array}{l}\text { Sporadanthus } \\
\text { cuticles }\end{array}$ & 1 & 1 & 5 & & 4 & & 32 & 2 \\
\hline $\begin{array}{l}\text { Empodisma } \\
\text { cuticles }\end{array}$ & 17 & 12 & 43 & 56 & 18 & 20 & 1 & 2 \\
\hline $\begin{array}{l}\text { sedge } \\
\text { cuticles }\end{array}$ & 18 & 29 & 13 & 8 & 7 & & & 2 \\
\hline $\begin{array}{l}\text { Gleichenia } \\
\text { cuticles }\end{array}$ & 3 & 3 & 4 & 12 & 15 & 8 & 34 & 45 \\
\hline $\begin{array}{l}\text { Leptospermum } \\
\text { cuticles }\end{array}$ & 2 & & & & & & & \\
\hline $\begin{array}{l}\text { monocot } \\
\text { cuticles }\end{array}$ & 25 & 1 & 13 & 5 & 3 & 31 & 36 & 7 \\
\hline $\begin{array}{l}\text { others } \\
\text { cuticles }\end{array}$ & 45 & 62 & 52 & 48 & 74 & 41 & 47 & 61 \\
\hline $\begin{array}{l}\begin{array}{l}\text { macroscopic } \\
\text { charcoal }\end{array} \\
\end{array}$ & 844 & 760 & 1123 & 1945 & 2737 & 2157 & 1097 & 2280 \\
\hline fern sporangia & 98 & 61 & 95 & 136 & 81 & 123 & 175 & 77 \\
\hline $\begin{array}{l}\text { Fruits\&Seeds, } \\
\text { Type } 1 \\
\end{array}$ & 6 & 2 & 4 & 6 & 1 & 6 & 13 & 10 \\
\hline $\begin{array}{l}\text { Fruits\&Seeds, } \\
\text { Type } 2\end{array}$ & 1 & & 3 & 1 & 2 & 4 & 8 & 7 \\
\hline
\end{tabular}




\begin{tabular}{|c|c|c|c|c|c|c|c|c|}
\hline & F2A -4 & F2A -3 & F2A -2 & F2A -1 & F2A 0 & F2A +1 & F2A +2 & F2A +3 \\
\hline $\begin{array}{l}\text { sampling } \\
\text { interval }(\mathrm{cm})\end{array}$ & $40-41$ & $41-42$ & $42-43$ & $43-44$ & $44-45$ & $45-46$ & $46-47$ & $47-48$ \\
\hline weight (g) & 2.03 & 2.02 & 2.02 & 2.01 & 2.05 & 2.04 & 2.04 & 2.04 \\
\hline depth (cm) & 139 & 140 & 141 & 142 & 143 & 144 & 145 & 146 \\
\hline age (cal yr BP) & 2667 & 2688 & 2710 & 2731 & 2752 & 2774 & 2795 & 2817 \\
\hline cuticles (total) & 132 & 112 & 118 & 103 & 98 & 100 & 121 & 98 \\
\hline $\begin{array}{l}\text { Sporadanthus } \\
\text { cuticles }\end{array}$ & 2 & & 9 & 2 & 2 & 2 & 6 & 1 \\
\hline $\begin{array}{l}\text { Empodisma } \\
\text { cuticles }\end{array}$ & 57 & 38 & 24 & 10 & 2 & $\overline{6}$ & 52 & 14 \\
\hline $\begin{array}{l}\text { sedge } \\
\text { cuticles }\end{array}$ & & & 1 & 3 & & 4 & 17 & 14 \\
\hline $\begin{array}{l}\text { Gleichenia } \\
\text { cuticles }\end{array}$ & 10 & 6 & 9 & 13 & 20 & 16 & 12 & 21 \\
\hline $\begin{array}{l}\text { Leptospermum } \\
\text { cuticles }\end{array}$ & 3 & 5 & 3 & 7 & 8 & 13 & & 6 \\
\hline $\begin{array}{l}\text { monocot } \\
\text { cuticles }\end{array}$ & 6 & 3 & 1 & 11 & 4 & 4 & 4 & 1 \\
\hline others cuticles & 54 & 60 & 71 & 57 & 62 & 55 & 30 & 41 \\
\hline $\begin{array}{l}\text { macroscopic } \\
\text { charcoal }\end{array}$ & 846 & 1414 & 1378 & 1165 & 948 & 997 & 1357 & 673 \\
\hline fern sporangia & 10 & 4 & 14 & & 9 & 14 & 4 & 8 \\
\hline $\begin{array}{l}\text { Fruits\&Seeds, } \\
\text { Type } 1 \\
\end{array}$ & 4 & & 2 & & 3 & 1 & & 2 \\
\hline $\begin{array}{l}\text { Fruits\&Seeds, } \\
\text { Type } 2 \\
\end{array}$ & 2 & 1 & 1 & & & 1 & 2 & 2 \\
\hline $\begin{array}{l}\text { Fruits\&Seeds, } \\
\text { Type } 4\end{array}$ & 2 & & & & & & & \\
\hline
\end{tabular}




\begin{tabular}{|c|c|c|c|c|c|c|c|c|}
\hline & F6A -4 & F6A -3 & F6A -2 & F6A -1 & F6A 0 & F6A +1 & F6A +2 & F6A +3 \\
\hline $\begin{array}{l}\text { sampling } \\
\text { interval }(\mathrm{cm})\end{array}$ & $15-16$ & $16-17$ & $17-18$ & $18-19$ & $19-20$ & $20-21$ & $21-22$ & $22-23$ \\
\hline weight (g) & 2.03 & 2.04 & 2.03 & 2.03 & 2.03 & 2.04 & 2.02 & 2.04 \\
\hline depth $(\mathrm{cm})$ & 510 & 511 & 512 & 513 & 514 & 515 & 516 & 517 \\
\hline age (cal yr BP) & 10291 & 10312 & 10333 & 10354 & 10376 & 10397 & 10417 & 10437 \\
\hline cuticles (total) & 98 & 155 & 126 & 127 & 130 & 125 & 117 & 117 \\
\hline $\begin{array}{l}\text { Empodisma } \\
\text { cuticles }\end{array}$ & & & & 3 & 1 & 1 & 2 & 1 \\
\hline $\begin{array}{l}\text { sedge } \\
\text { cuticles }\end{array}$ & 52 & 76 & 57 & 74 & 74 & 65 & 68 & 62 \\
\hline $\begin{array}{l}\text { Gleichenia } \\
\text { cuticles }\end{array}$ & & 10 & & 4 & 8 & 4 & 23 & 1 \\
\hline $\begin{array}{l}\text { Leptospermum } \\
\text { cuticles }\end{array}$ & & & 1 & & & & & \\
\hline $\begin{array}{l}\text { monocot } \\
\text { cuticles }\end{array}$ & 2 & 6 & 3 & 3 & & 2 & & \\
\hline $\begin{array}{l}\text { others } \\
\text { cuticles }\end{array}$ & 44 & 63 & 65 & 43 & 47 & 53 & 24 & 53 \\
\hline $\begin{array}{l}\text { macroscopic } \\
\text { charcoal }\end{array}$ & 332 & 144 & 289 & 534 & 1786 & 504 & 381 & 1341 \\
\hline fern sporangia & 14 & 4 & 2 & 3 & 0 & 1 & 4 & 1 \\
\hline $\begin{array}{l}\text { Fruits\&Seeds, } \\
\text { Type } 1\end{array}$ & & & & & 5 & & & \\
\hline $\begin{array}{l}\text { Fruits\&Seeds, } \\
\text { Type } 2\end{array}$ & 2 & & & 3 & & 1 & 1 & 1 \\
\hline $\begin{array}{l}\text { Fruits\&Seeds, } \\
\text { Type } 4\end{array}$ & 4 & 4 & 4 & 2 & & & 1 & \\
\hline
\end{tabular}


3.2 raw bulk density and organic matter data

\begin{tabular}{|c|r|r|l|r|r|r|r|r|}
\hline $\begin{array}{l}\text { Depth } \\
(\mathbf{c m})\end{array}$ & $\begin{array}{l}\text { Bulk } \\
\text { density } \\
\left(\mathbf{g} / \mathbf{c m}^{\mathbf{3}}\right)\end{array}$ & $\begin{array}{l}\text { organic } \\
\text { matter } \\
(\mathbf{\%})\end{array}$ & $\begin{array}{l}\text { Depth } \\
(\mathbf{c m})\end{array}$ & $\begin{array}{l}\text { Bulk } \\
\text { density } \\
\left(\mathbf{g} / \mathbf{c m}^{\mathbf{3}}\right)\end{array}$ & $\begin{array}{l}\text { organic } \\
\text { matter } \\
(\boldsymbol{\%})\end{array}$ & $\begin{array}{l}\text { Depth } \\
(\mathbf{c m})\end{array}$ & $\begin{array}{l}\text { Bulk } \\
\text { density } \\
\left(\mathbf{g} / \mathbf{c m}^{\mathbf{3}}\right)\end{array}$ & $\begin{array}{l}\text { organic } \\
\text { matter } \\
(\boldsymbol{\%})\end{array}$ \\
\hline $\mathbf{1 3 9}$ & 0.088 & 97.094 & $\mathbf{2 8 2}$ & 0.105 & 97.644 & $\mathbf{5 1 0}$ & 0.109 & 84.079 \\
\hline $\mathbf{1 4 0}$ & 0.081 & 97.640 & $\mathbf{2 8 3}$ & 0.093 & 97.258 & $\mathbf{5 1 1}$ & 0.119 & 85.523 \\
\hline $\mathbf{1 4 1}$ & 0.084 & 96.842 & $\mathbf{2 8 4}$ & 0.083 & 97.401 & $\mathbf{5 1 2}$ & 0.120 & 90.160 \\
\hline $\mathbf{1 4 2}$ & 0.091 & 96.379 & $\mathbf{2 8 5}$ & 0.086 & 97.305 & $\mathbf{5 1 3}$ & 0.112 & 89.444 \\
\hline $\mathbf{1 4 3}$ & 0.087 & 97.140 & $\mathbf{2 8 6}$ & 0.105 & 97.328 & $\mathbf{5 1 4}$ & 0.126 & 92.762 \\
\hline $\mathbf{1 4 4}$ & 0.104 & 96.602 & $\mathbf{2 8 7}$ & 0.097 & 97.601 & $\mathbf{5 1 5}$ & 0.123 & 93.256 \\
\hline $\mathbf{1 4 5}$ & 0.116 & 97.657 & $\mathbf{2 8 8}$ & 0.100 & 97.837 & $\mathbf{5 1 6}$ & 0.181 & 92.457 \\
\hline $\mathbf{1 4 6}$ & 0.138 & 97.448 & $\mathbf{2 8 9}$ & 0.087 & 97.711 & $\mathbf{5 1 7}$ & 0.103 & 91.667 \\
\hline $\mathbf{-}$ & & & - & & & $\mathbf{5 1 7}$ & 0.103 & 91.738 \\
\hline- & & & - & & & $\mathbf{5 1 7}$ & 0.111 & 91.661 \\
\hline
\end{tabular}




\section{Contributions}

4.1 sample depths of plant macrofossils used for radiocarbon dating and resulting radiocarbon ages

(data from Ignacio Jara, VUW)

\begin{tabular}{|l|l|c|c|c|}
\hline $\begin{array}{l}\text { Sample } \\
\text { ID }\end{array}$ & drive & $\begin{array}{l}\text { depth } \\
(\mathbf{c m})\end{array}$ & ${ }^{14}$ C age & Error \\
\hline $\mathbf{4 0 6 5 0 / 1 5}$ & 1202R2B & 183 & 3399 & 25 \\
\hline $\mathbf{4 0 6 5 0 / 1 3}$ & $1202 \mathrm{R} 4 \mathrm{~B}$ & 354 & 6251 & 28 \\
\hline $\mathbf{4 0 6 5 0 / 1 2}$ & $1202 \mathrm{R} 5 \mathrm{~B}$ & 451 & 8173 & 33 \\
\hline $\mathbf{4 0 6 5 0 / 1 6}$ & $1202 \mathrm{R} 6 \mathrm{~A}$ & 517 & 9294 & 36 \\
\hline $\mathbf{4 0 6 5 0 / 7}$ & 1202R6B & 561 & 10068 & 38 \\
\hline $\mathbf{4 0 6 5 0 / 1 1}$ & 1202R7A & 597 & 11867 & 46 \\
\hline $\mathbf{4 0 6 5 0 / 1 7}$ & 1201R7B & 691 & 12230 & 39 \\
\hline $\mathbf{4 0 6 5 0 / 8}$ & 1201R8A & 730 & 12267 & 47 \\
\hline
\end{tabular}


4.2 pollen record (data from Ignacio Jara, VUW)

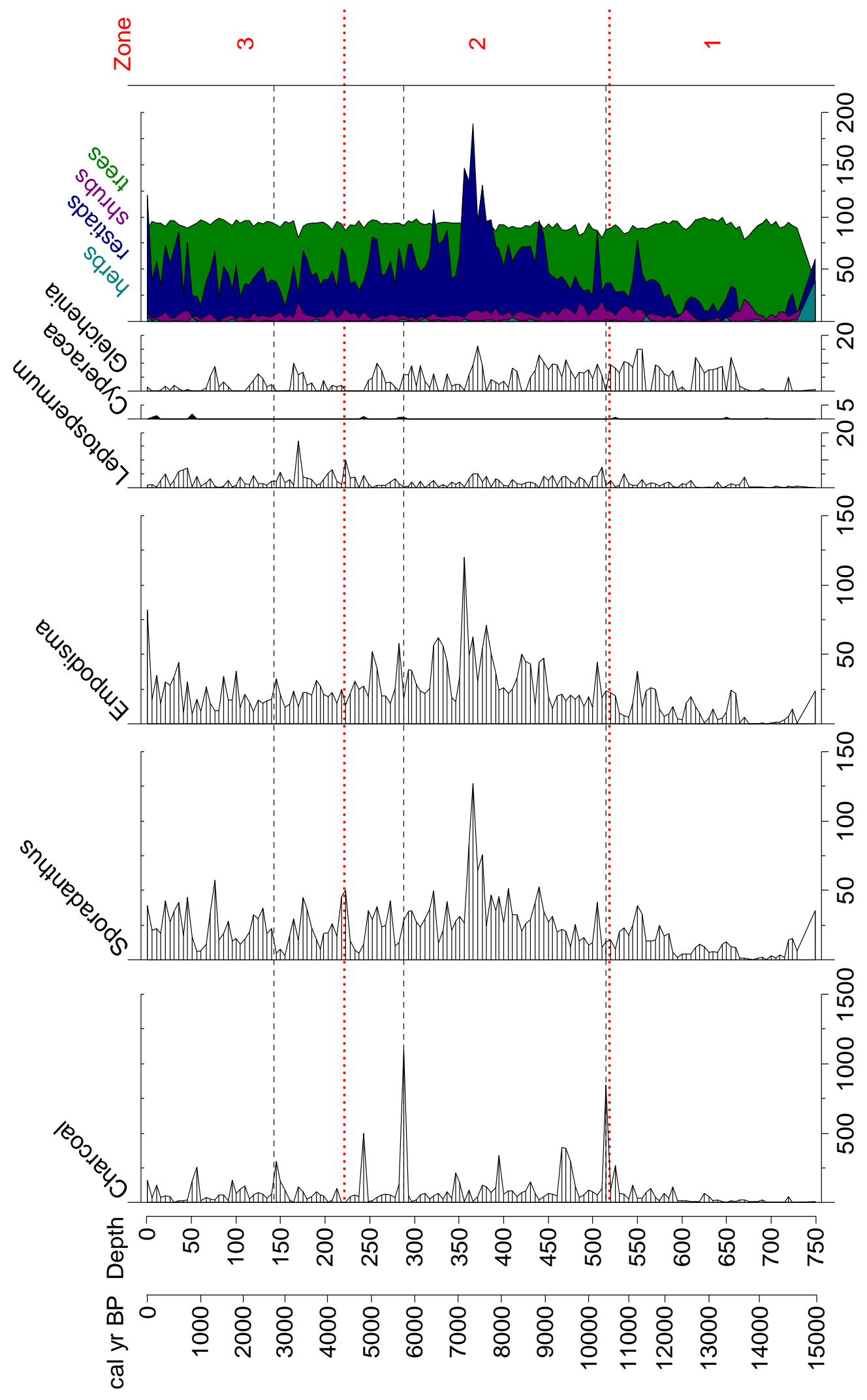

